\title{
Richland Operations Office Implementation Plan for DOE Order 435.1
}

Prepared for the U.S. Department of Energy

Assistant Secretary for Environmental Management

Project Hanford Management Contractor for the

U.S. Department of Energy under Contract DE-AC06-96RL13200

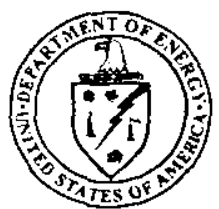

United States

Department of Energy

P.O. Box 550

Richland, Washington 99352 
DOE/RL-2000-25

Revision 1

\section{Richland Operations Office Implementation Plan for DOE Order 435.1}

Date Published

June 2000

Prepared for the U.S. Department of Energy

Assistant Secretary for Environmental Management

Project Hanford Management Contractor for the

U.S. Department of Energy under Contract DE-AC06-96RL13200

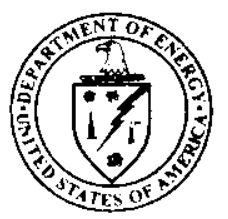

\section{United States}

Department of Energy

P.O. Box 550

Richland, Washington 99352

$\frac{\text { Chiv Hollengand }}{\text { Release Approval }} \frac{6 / 16 / 00}{\text { Date }}$ 
LEGAL DISCLAIMER

This report was prepared as an account of work sponsored by an agency of the United States Government. Neither the

United States Government nor any agency thereof, nor any of their employees, nor any of their contractors, subcontractors or their employees, makes any warranty, express or implied, or assumes any legal liability or responsibility for the accuracy, completeness, or any third party's use or the results of such use of any information, apparatus, product, or process disclosed, or represents that its use would not infringe privately owned rights. Reference herein to any specific commercial product, process, or service by trade name, trademark, manufacturer, or otherwise, does not necessarily constitute or imply its endorsement, recommendation, or favoring by the United States Government or any agency thereof or its contractors or subcontractors. The views and opinions of authors expressed herein do not necessarily state or reflect those of the United States Government or any agency thereof.

This report has been reproduced from the best available copy. 


\section{CONTENTS}

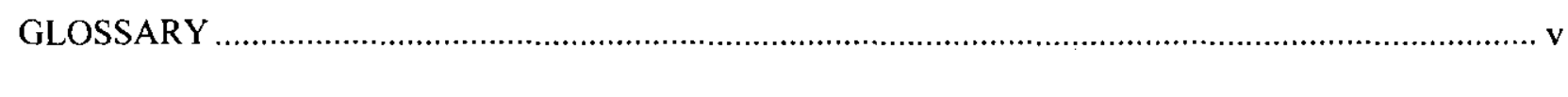

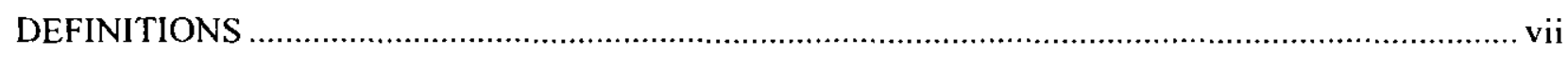

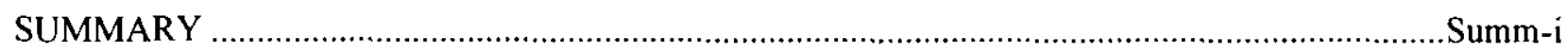

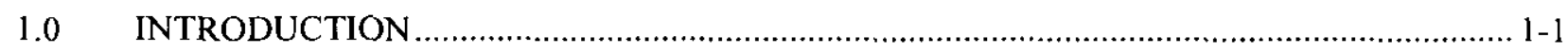

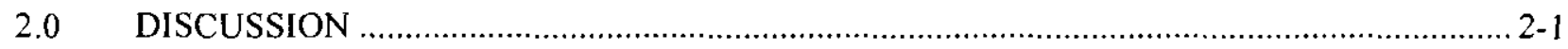

2.1 DOE ORDERS NOT IN ALL CONTRACTS …...................................................... 2-1

2.2 BASIS, ASSUMPTIONS, AND INTERPRETATIONS …............................................ 2-1

2.2.1 Determination of High Activity and High Hazard Low-Level Liquid Waste Pursuant to DOE Manual 435.1-1 Chapter IV E(1) .............................................................................. 2-6

2.2.2 Implementation of 90-Day Staging Clock for Newly Generated Low-Level Waste .................. 2-6

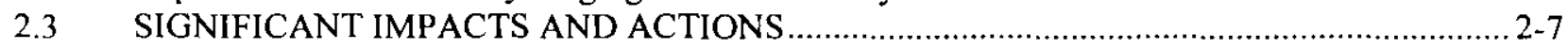

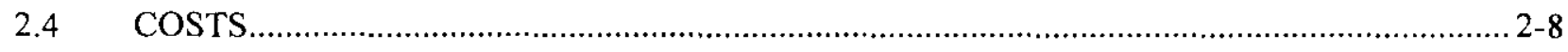

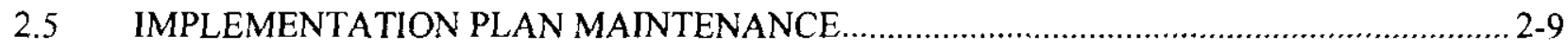

APPENDIX

A DOE ORDER 435.1 IMPLEMENTATION PLAN …................................................ APP A-i

TABLE

Table 2-1. DOE Orders and Directives Listed in DOE Order 435.1 ............................................ T2-1 
DOE/RL-2000-25, Rev. 1

06/2000

This page intentionally left blank. 


\section{GLOSSARY}

AE

ALARA

BHI

CERCLA

$\mathrm{CO}$

CRD

CSB

$\mathrm{CWC}$

DOE

DOE-RL

DynCorp

ERDF

ETF

FAR

FFTF

FH

HIC

HNF

INEEL

IP

ISMS

LDR

LERF

LLBG

LWPF

MYWP

PFP

PNNL

PUREX

RCP

RCRA

RWMB

SNF

S/RID

TA

Tri-Party Agreement authorization envelope

as low as reasonably achievable

Bechtel Hanford, Incorporated

Comprehensive Environmental Response, Compensation and Liability Act of 1980

company

contractor requirements document

Canister Storage Building

Central Waste Complex

U.S. Department of Energy

U.S. Department of Energy, Richland Operations Office

DynCorp Tri-Cities Services, Inc.

Environmental Restoration Disposal Facility

200 Area Effluent Treatment Facility

federal acquisition regulation

Fast Flux Test Facility

Fluor Hanford

high integrity container

Hanford Nuclear Facility (document identifier)

Idaho National Environmental Engineering Laboratory

implementation plan

Integrated Environmental, Safety and Health Management System

land disposal restrictions

Liquid Effluent Retention Facility

Low-Level Burial Grounds

Liquid Waste Processing Facilities

multi-year work plan

Plutonium Finishing Plant

Pacific Northwest Nationa! Laboratory

plutonium-uranium extraction

River Corridor Project

Resource Conservation and Recovery Act of 1976

radioactive waste management basis

spent nuclear fuel

standards/requirements identification document

technical authority

Hanford Federal Facility and Consent Order 
DOE/RL-2000-25, Rev. 1

$06 / 2000$

TRUPACT

TSD

WESF

WMP

WRAP transuranic package transporter treatment, storage, and/or disposal

Waste Encapsulation and Storage Facility Waste Management Project

Waste Receiving and Processing Facility 


\section{DEFINITIONS}

The following definitions are from DOE Manual 435.1.

1. AUTHORIZATION BASIS. Those aspects of the facility design basis and operational requirements relied upon by DOE to authorize operation. They are considered to be important to the safety of the facility operations. The authorization basis is described in documents such as the facility Safety Analysis Report and other safety analysis; Hazard Classification Documents, Technical Safety Requirements, DOE-issued safety evaluation reports, and facility-specific commitments made in order to comply with DOE Orders or policies (Adapted from: DOE Glossary, DOE 5480.2 I and DOE 5480.23).

2. BYPRODUCT MATERIAL. (1) Any radioactive material (except special nuclear material) yielded in or made radioactive by exposure to the radiation incident to the process of producing or utilizing special nuclear material, and (2) the tailings or wastes produced by the extraction or concentration of uranium or thorium from any ore processed primarily for its source material content [Source: Atomic Energy Act of 1954, as amended, section 11(e)].

3. CANISTERED WASTE FORM. High-level waste form in a sealed canister (Source: EM-WAPS, DOE/EM-0093).

4. CLOSURE. Deactivation and stabilization of a radioactive waste facility intended for long-term confinement of waste (No other source of definition identified).

5. COMPOSITE ANALYSIS. An analysis that accounts for all sources of radioactive material that may contribute to the long-term dose projected to a hypothetical member of the public from an active or planned low-level waste disposal facility. The analysis is a planning tool intended to provide a reasonable expectation that current low-level waste disposal activities will not result in the need for future corrective or remedial actions to ensure protection of the public and the environment (Adapted from: Revised Interim DOE Policy on Management Direction and Oversight of Low-Level Radioactive Waste Management Disposal).

6. CONFINEMENT. The control or retention of radioactive materials within a designated boundary. Primary confinements are process enclosures and other spaces normally containing radioactive material. Secondary confinement surrounds one or more primary confinement systems (Adapted from: DOE 6430.1A).

7. CONTAINER. Refer to WASTE CONTAINER.

8. DEACTIVATED HIGH-LEVEL WASTE FACILITY. A high-level waste facility that has been put into a stable condition through the removal of readily retrievable hazardous and radioactive materiats to protect the worker, public health and safety, and the environment, thereby limiting the long-term cost of surveillance and maintenance. A facility in a deactivated status has not had all necessary decontamination performed, e.g., removal of contamination remaining in fixed structures and equipment after deactivation (Adapted from: DOE O 430.1A).

9. DEFENSE-IN-DEPTH. The practice of using physical systems and administrative systems in a structure of mutual reinforcement to avoid exposure of the public, the workforce, and the environment to nuclear radiation and to radioactive materials (Source: Defense Nuclear Facility Safety Board/TECH-6). 
10. DEPARTMENTAL ELEMENTS. First-tier organizations at Headquarters and in the Field. Firsttier at Headquarters is the Secretary, Deputy Secretary, Under Secretary, and Secretarial Officers (Assistant Secretaries and Staff Office Directors). First-tier in the Field is Managers of the eight Operations Offices, Managers of the three Field Offices, and the Administrators of the Power Marketing Administrations. Headquarters and Field Elements are described as follows: (1) Headquarters Elements are DOE organizations located in the Washington, DC, Metropolitan Area; and (2) Field Elements is a general term for all DOE sites (excluding individual duty stations) located outside of the Washington, DC, Metropolitan Area (Source: DOE Glossary).

11. DESIGN BASIS. Information that identifies the specific functions to be performed by a structure, system, or component of a facility, and the specific values or range of values chosen for controlling parameters as reference bounds of design. These values may be (1) restraints derived from generally accepted "state of the art" practices for achieving functional goals, or (2) requirements derived from analyses (based on calculations and/or experiments) of the effects of a postulated accident for which a structure, system, or component must meet its functional goals (Adapted from: 10 CFR Part 50).

12. DISPOSAL. Emplacement of waste in a manner that ensures protection of the public, workers, and the environment with no intent of retrieval and that requires deliberate action to regain access to the waste (Adapted from: DOE 5820.2A).

13. DISPOSAL AUTHORIZATION STATEMENT. Documentation authorizing operation (or continued operation) of a low-level waste disposal facility resulting from the DOE Headquarters review and acceptance of the facility's performance assessment, composite analysis, and other information and evaluations. The disposal authorization statement constitutes approval of the performance assessment and composite analysis, authorizes operation of the facility, and includes conditions the disposal facility must meet (Adapted from: Revised Interim DOE Policy Management Direction and Oversight of Low-Level Radioactive Waste Management and Disposal).

14. DISPOSITION. Those activities that follow generation of a waste and which constitute completion of the life cycle of management of the waste, including, but not limited to, stabilization, deactivation, disposal, decommissioning, dismantlement, and/or reuse (Adapted from: DOE O 430.1).

15. EFFLUENT. Any treated or untreated air emission or liquid discharge at a DOE site or from a DOE facility (Source: DOE 5400.1).

16. FACILITY. Refer to RADIOACTIVE WASTE MANAGEMENT FACILITY.

\section{FIELD ELEMENT. Refer to DEPARTMENTAL ELEMENTS.}

\section{FIELD ELEMENT MANAGER. Refer to DEPARTMENTAL ELEMENTS.}

19. GENERATOR. Organizations within DOE or managed by DOE whose act or process produces radioactive waste or, for the purposes of the generator requirements in this Order and Manual, transfer radioactive waste to a treatment, storage, or disposal facility (Adapted from: 40 CFR Part 270).

20. GRADED APPROACH. A process by which the level of analysis, documentation, and actions necessary to comply with a requirement are commensurate with (1) the relative importance to safety, safeguards, and security; (2) the magnitude of any hazard involved; (3) the life cycle stage of a facility; (4) the programmatic mission of a facility; (5) the particular characteristics of a facility; and (6) any other relevant factor (Source: 10 CFR 830.3). 
21. HAZARD. A source of danger (i.e., material, energy source, or operation) with the potential to cause illness, injury, or death to personnel or damage to an operation or to the environment (without regard for the likelihood or credibility of accident scenarios or consequence mitigation) (Source: DOE M 411.1-1).

22. HIGH-LEVEL WASTE. High-level waste is the highly radioactive waste material resulting from the reprocessing of spent nuclear fuel, including liquid waste produced directly in reprocessing and any solid material derived from such liquid waste that contains fission products in sufficient concentrations; and other highly radioactive material that is determined, consistent with existing law, to require permanent isolation (Adapted from: Nuclear Waste Policy Act of 1982, as amended).

23. LESSONS LEARNED. The process for communicating a "good work practice" or innovative approach that should be implemented or an adverse work practice or experience that should be avoided (Adapted from: DOE M 232.1-1A).

24. LIFE CYCLE. The life of a waste from generator planning through generation, storage, treatment, and disposal (Adapted from: DOE O 430.1A).

25. LOW-LEVEL WASTE. Low-level radioactive waste is radioactive waste that is not high-level radioactive waste, spent nuclear fuel, transuranic waste, byproduct material (as defined in section 11 e.(2) of the Atomic Energy Act of 1954, as amended), or naturally occurring radioactive material. [Adapted from: Nuclear Waste Policy Act of 1982, as amended).

26. MAINTENANCE. Day-to-day work, including preventive and predictive maintenance, that is required to maintain and preserve plant and capital equipment in a condition suitable for it to be used for its designated purpose (Source: DOE O 430.1A).

27. MIXED WASTE. Waste that contains both source, special nuclear, or by-product material subject to the Atomic Energy Act of 1954, as amended, and a hazardous component subject to the Resource Conservation and Recovery Act of 1976 (Adapted from: Federal Facility Compliance Act of 1992).

28. NATURALLY OCCURRING RADIOACTIVE MATERIAL (NORM). Naturally occurring materials not regulated under the Atomic Energy Act of 1954, as amended whose composition, radionuclide concentrations, availability, or proximity to man have been increased by or as a result of human practices. NORM does not include the natural radioactivity of rocks or soils, or background radiation (Adapted from: January 1997 Draft Part N, Regulation and Licensing of Naturally Occurring Radioactive Material, Conference of Radiation Control Program Directors, Inc.).

29. NEAR SURFACE DISPOSAL. Disposal of radioactive waste on or near the earth's surface. The term encompasses a wide range of methods, including disposal in earthen trenches several meters deep, disposal in engineered structures constructed on or below the surface, and disposal in structures or rock caverns tens of meters below the earth's surface. Near surface disposal does not include disposal in a deep geologic repository (Adapted from: IAEA Safety Standard No. 111-S-3).

30. NECESSARY AND SUFFICIENT PROCESS. The sets of standards that are the product of the "Necessary and Sufficient Process" of DOE M 450.3-1. That process establishes the sets of agreed upon standards to ensure adequate protection of the safety and health of workers and the public and the protection of the environment against the hazards associated with performing the work of the DOE (Adapted from: DOE G 450.3-1).

31. OVERSIGHT. The responsibility and authority assigned to line management to assess the adequacy of DOE and contractor performance. Independent Oversight refers to the responsibility and 
authority assigned to the Assistant Secretary for Environment, Safety and Health to independently assess the adequacy of DOE and contractor performance (Adapted from: DOE M 411.1-1).

32. PERFORMANCE ASSESSMENT. An analysis of a radioactive waste disposal facility conducted to demonstrate there is a reasonable expectation that performance objectives established for the longterm protection of the public and the environment will not be exceeded following closure of the facility (Adapted from: DOE 5820.2A).

33. PROGRAM SECRETARIAL OFFICER. Head of a Departmental Element who has responsibility for a specific program or facility(ies). These include the Assistant Secretaries for Defense Programs, Energy Efficiency and Renewable Energy, Environmental Management, and Fossil Energy; and the Directors of the Offices of Civilian Radioactive Waste Management, Science, and Nuclear Energy; and (2) a Cognizant Secretarial Officer is a DOE official at the Assistant Secretary level who is responsible for the assignment of work, the institutional overview of any type of facility, or both, and the management oversight of a laboratory (Source: DOE M 232.1-1A).

34. RADIOACTIVE MIXED WASTE. Refer to MIXED WASTE.

35. RADIOACTIVE WASTE. Any garbage, refuse, sludges, and other discarded material, including solid, liquid, semisolid, or contained gaseous material that must be managed for its radioactive content (Adapted from: 40 CFR Part 240).

36. RADIOACTIVE WASTE MANAGEMENT BASIS. The radioactive waste management controls applied to DOE facilities, operations, and activities to provide near- and long-term protection of public, workers, and the environment. The radioactive waste management basis (RWMB) consists of controls and analyses such as facility waste certification programs, facility waste acceptance requirements, low-level waste disposal facility closure plans, performance assessments, composite analyses, and other facility-specific processes, procedures, and analyses made to comply with DOE O 435.1 and its Manual.

37. RADIOACTIVE WASTE MANAGEMENT FACILITY/OPERATIONS/ACTIVITIES. All land, structures, other appurtenances, and improvements on the land which generate, treat, store, or dispose of radioactive waste, and the operations and activities associated therewith (Adapted from: DOE 5820.2A).

38. RECORD. A completed document or other medium that provides objective evidence of an item, service, or process (Source: 10 CFR 830.3).

39. RELEASE. Any discharging, dumping, emitting, emptying, escaping, injecting, leaching, leaking, pouring, pumping, spilling of radioactive substances into the environment including abandoning any type of receptacle containing radioactive substances, but does not include disposal in a permitted disposal facility (Adapted from: DOE Glossary).

40. RELEASE OF WASTE. The exercising of DOE's authority to release property that has been declared waste from its control after confirming that residual radioactive material on the waste has been determined to meet the guidelines for residual radioactive material in accordance with DOE 5400.5, Radiation Protection of the Public and the Environment, and other applicable radiological requirements (Adapted from: DOE 5400.5).

41. SITE. A geographic entity comprising leased or owned land, buildings, and other structures required to perform program activities (Source: DOE O 430.1A). 
42. SOURCE MATERIAL. (1) Uranium or thorium, or any combination thereof, in any physical or chemical form or (2) ores which contain by weight one-twentieth of one percent $(0.05 \%)$ or more of (i) uranium, (ii) thorium or (iii) any combination thereof. Source material does not include special nuclear material (Source: 10 CFR Part 40).

43. SPECIAL NUCLEAR MATERIAL. (1) Plutonium, uranium enriched in the isotope 233 or in the isotope 235, and any other material which is determined, pursuant to the provisions of section 51 [of the Atomic Energy Act of 1954, as amended], to be special nuclear material, but does not include source material; or (2) any material artificially enriched by any of the foregoing, but does not include source material (Source: Atomic Energy Act of 1954, as amended).

44. SPENT NUCLEAR FUEL. Fuel that has been withdrawn from a nuclear reactor following irradiation, the constituent elements of which have not been separated by reprocessing. Test specimens of fissionable material irradiated for research and development only, and not production of power or plutonium, may be classified as waste, and managed in accordance with the requirements of this Order when it is technically infeasible, cost prohibitive, or would increase worker exposure to separate the remaining test specimens from other contaminated material (Adapted from: DOE 5820.2A).

45. STAGING. Storing waste for the purpose of accumulation to facilitate transportation transfer, treatment and/or disposal (Adapted from: Surplus Plutonium Disposition Draft Environmental Impact Statement, July 1998).

46. STORAGE. The holding of radioactive waste for a temporary period, at the end of which the waste is treated, disposed of, or stored elsewhere (Adapted from: 40 CFR Part 260).

47. STORAGE FOR DECAY. Storage of radioactive waste for a period of time sufficient for radionuclide(s) of concern to be reduced in concentration, by radioactive decay, to a level of lower concern (Source: DOE 5820.2A).

48. SYSTEMS ENGINEERING. A total systematic approach for the development of systems in response to a defined need. It involves a comprehensive, structured and disciplined approach to all life-cycle phases. Systems Engineering employs a multi-discipline team to iteratively define and refine solutions to problems throughout the system life cycle. Preferred alternatives are selected based on cost, schedule, performance and risk. Management of risk is integral to the process. Progressive verification, from individual components up through the total system, is required (Source: ElA-632, Systems Engineering).

49. TRANSURANIC WASTE. Transuranic waste is radioactive waste containing more than 100 nanocuries ( 3700 becquerels) of alpha-emitting transuranic isotopes per gram of waste, with half-lives greater than 20 years, except for: (1) high-Jevel radioactive waste; (2) waste that the Secretary of Energy has determined, with the concurrence of the Administrator of the Environmental Protection Agency, does not need the degree of isolation required by the 40 CFR Part 191 disposal regulations; or (3) waste that the Nuclear Regulatory Commission has approved for disposal on a case-by-case basis in accordance with 10 CFR Part 61 (Source: WIPP Land Withdrawal Act of 1992, as amended).

50. TREATMENT. Any method, technique, or process designed to change the physical or chemical character of waste to render it: less hazardous; safer to transport, store, or dispose; or reduce its volume (Source: DOE 5820.2A). 
51. WASTE ACCEPTANCE CRITERIA. Waste acceptance criteria are the technical and administrative requirements that a waste must meet for the waste to be accepted at a storage, treatment, or disposal facility (Adapted from: DOE 5820.2A).

52. WASTE ACCEPTANCE REQUIREMENTS. Waste acceptance requirements are waste acceptance criteria, and all other requirements that a facility receiving radioactive waste for storage, treatment, or disposal must meet to receive waste (e.g., waste acceptance program requirements, receiving facility operations manual) (Adapted from: DOE O 5820.2A).

53. WASTE CHARACTERIZATION. The identification of waste composition and properties, by review of acceptable knowledge (which includes process knowledge), or by nondestructive examination, nondestructive assay, or sampling and analysis, to comply with applicable storage, treatment, handling, transportation, and disposal requirements [Adapted from: DOE Glossary ("Characterization" definition) and Federal Register, Vol. 62, No. 224].

54. WASTE CERTIFICATION. A process by which a waste generator affirms that a given waste or waste stream meets the waste acceptance criteria of the facility to which the generator intends to transfer waste for treatment, storage, or disposal (Adapted from: DOE 5820.2A).

55. WASTE CONTAINER. A receptacle for waste, including any liner, shielding, or material that is intended to accompany the waste in disposal (Adapted from: DOE 5820.2A).

56. WASTE MANAGEMENT. The planning, coordination, and direction of those functions related to generation, handling, treatment, storage, transportation, and disposal of waste, as well as associated surveillance and maintenance activities (Source: DOE 5820.2A).

57. WASTE STREAM. A waste or group of wastes from a process or a facility with similar physical, chemical, or radiological properties (Adapted from: DOE 5820.2A). 


\section{SUMMARY}

The U.S. Department of Energy issued U.S. Department of Energy Order 435.1, Radioactive Waste Management, and U.S. Department of Energy Manual 435.1-1, Radioactive Waste Management Manual, on July 9, 1999, to replace U.S. Department of Energy Order 5820.2A. Compliance is required by July 9 , 2000 , where compliance is defined as "implementing the requirements, or an approved implementation, or corrective action plan" (refer to Manual, Introduction, paragraph four).

This implementation plan identifies the status of each requirement for U.S. Department of Energy, Richland Operations Office Site contractors, and provides the plan, cost, and length of time required for achieving full implementation.

The U.S. Department of Energy, Richland Operations Office contractors (Fluor Hanford, Incorporated, DynCorp Tri-Cities Services, Bechtel Hanford, Inc., and Pacific Northwest National Laboratory) conducted a line-by-line review of DOE Order 435.1 and associated manuals to determine which requirements were new, and which requirements already are used for compliance with the previous DOE Order 5820.2A or other requirements. The Gap Analysis for DOE Order 435.1 (HNF-5465) identified compliance gaps, along with other issues that would impact efforts for achieving compliance. The gap analysis also contained a series of assumptions made by the various projects in determining compliance status. The details and section-by-section analysis are contained in Appendix A.

Some of the DOE Order 435.1 requirements invoke sections of other DOE Orders not incorporated in various U.S. Department of Energy, Richland Operations Office contracts (refer to Section 2.0, Table 2-1). Those additional DOE Orders are identified by contractor and will be left for evaluation in accordance with each contractor's requirements. No attempt was made to evaluate all of those orders at this time, although in many cases, contractors follow a similar older DOE Order, which is cited in the Appendix.

In some areas, the interpretation of the requirement is not clear, so clarifying assumptions have been made to assist the U.S. Department of Energy, Richland Operations Office in understanding the path forward planning basis. The assumptions and interpretations form the basis for the compliance gap analysis, as well as for the implementation plan itself as noted in Section 2.2. In some cases, the interpretation is essentially an exemption from a requirement, with the basis stated and justified. Some of the critical items in this area relate to the following:

1. Pre-existing waste

2. Staging and storage

3. Exemption of Comprehensive Environmental Response, Compensation, and Liability Act of 1980 remediation areas

4. Contingency and confinement requirements for old facilities

5. Siting and design requirement exemption for limited-lifetime facilities

6. Waste with no identified path to disposal

7. Characterization, packaging, storage, certification, and monitoring requirements that might not satisfy the letter of DOE Order 435.1 but are justified fully in related safety, environmental, or monitoring documents. 
Review of DOE Order 435.1 showed that a major change in management philosophy has occurred since the issuance of DOE Order 5820.2A. Most authority and responsibility has been delegated to DOE Field Element managers, who now will have approval authority for many actions, subject to the broad requirements of the DOE Order 435.1, Manual, and guidance. The requirements lean heavily on the systematic identification of activities and processes to manage the waste over the entire life cycle, with final disposal as the driving objective. Characterization and acceptance criteria have a much larger role, and far more detail is expected. The overall disposal process continues to be focused on results of the performance assessment to ensure that future populations are protected to the level of the performance objectives.

Substantial costs will be incurred to fully implement the Order. Those costs are summarized in the main text and detailed in the Appendix. Total cost is estimated to be $\$ 2.1$ million. 


\subsection{INTRODUCTION}

The U.S. Department of Energy (DOE) issued DOE Order 435.1, Radioactive Waste Management and DOE Manual 435.1-1, the Radioactive Waste Management Manual, on July 9, 1999, to replace DOE Order 5820.2A, Radioactive Waste Management. Compliance is required by July 9, 2000, where compliance is defined as "implementing the requirements, or an approved implementation or corrective action plan" (DOE M 435.1). The DOE, Richland Operations Office (DOE-RL) requested contractors to prepare impact assessments and related information necessary to provide an implementation plan (IP). Fluor Hanford (FH) was assigned the lead to coordinate a gap analysis to determine requirements already met by existing operations. Based on the impact assessment, $\mathrm{FH}$ also was requested to identify cost and operational changes needed to accomplish full compliance, and to prepare an IP for approval by DOE-RL by May 15, 2000. This IP is for DOE-RL Site contractors FH, DynCorp Tri-Cities Services, Inc.(DynCorp), Bechtel Hanford, Inc. (BHI), and Pacific Northwest National Laboratory (PNNL).

A gap analysis (HNF-5645) identified requirements not met by DOE-RL contractors. For each entry with a gap, a short statement of the need or issue was provided. In cases where there were differences among the contractors' status, the contractor or facility was identified. Contractors prepared plans, schedules, and costs to implement the Order.

The major portion of this IP is the compliance analysis, which is provided in tabular form in Appendix A. The first column cites the section of the Order, while the second column is the complete text of that section. The third column is the compliance status identified during the gap analysis, such that 'no gap' means full compliance. The fourth column contains the plan and schedule for compliance, and the last column is the estimated cost. Responses could be divided further by major project or contractor. 
This page intentionally left blank. 


\subsection{DISCUSSION}

This IP contains discussions for a few key issues, followed by an Appendix with all sections of the Manual and responses to the requirements in those sections.

Responses for FH can include projects, including FH-WMP (waste management and analytical services project), PFP (Plutonium Finishing Plant), FFTF (Fast Flux Test Facility), SNF (spent nuclear fuel stored in K-Basins), and RCP (River Corridor Project). Responses could be divided further for applicability to specific facilities, or groups of facilities, such as B Plant Complex, Canister Storage Building, 324 and 327 Buildings, LLBG (Low-Level Burial Grounds), WESF (Waste Encapsulation and Storage Facility), T Plant Complex, CWC (Central Waste Complex), WRAP (Waste Receiving and Processing Facility), PUREX Storage Tunnels, 242-A Evaporator, and others as noted. RCP manages a variety of facilities, including the 324/327 Buildings, $310 / 340$ Buildings, and several accelerated deactivation facilities in the 200 and 300 Areas. Responses from other contractors are referred to as $\mathrm{BHI}$ for the environmental restoration programs, PNNL for the laboratory programs, and DynCorp for site services. The responses are combined in Appendix A, indexed according to the Manual citation number.

\subsection{DOE ORDERS NOT IN ALL CONTRACTS}

The compliance analysis noted that some DOE Orders cited as required by DOE Order 435.1 and DOE Manual 435.1, Section I.E are not in all current contracts. The status for three major contractors (FH, $\mathrm{BHI}$, and PNNL) is given in Table 2-1 for Orders and directives cited in DOE Order 435.1. Standards also are included for completeness, although those Standards are considered to be guidance rather than mandatory. Some of the directives apply to DOE rather than to contractors as noted. Compliance with those Orders has not been evaluated at this time. An evaluation of compliance with those Orders will be made at the time the Orders are added to the existing contracts. The evaluation is not straightforward, because some contractors, which were previously under separate contracts, had differing sets of applicable Orders in their contracts. Those contracts recently have been combined under the FH management contract, so in principle the sets of Orders apply to all current $\mathrm{FH}$ activities. In the Appendix, the 'Status' column notes where there could be Orders cited that are not in all current contracts. In some cases, compliance is cited with existing Orders, which satisfies most of the requirements.

An additional temporary complication is that several $\mathrm{FH}$ facilities operate under Standards/Requirements Identification Documents (S/RIDs), which form the authorized safety basis for the facilities, and thus could exempt such facilities from later added Orders until the S/RIDs receive annual revision. The S/RIDs currently in effect are for FH-WMP, PFP, FFTF, WESF, SNF/Canister Storage Building (CSB)/K-Basins, and 324/327 Buildings. All S/RIDs are scheduled for revision at various dates through 01/19/2001, which will eliminate the issue.

\subsection{BASIS, ASSUMPTIONS, AND INTERPRETATIONS}

1. Approaches for dealing with waste pre-existing to implementation of DOE Order 435.1 include the following.

- Low-level waste pre-existing to implementation of DOE Order 435.1 storage or staging clock requirements [IV N(2) and (7)] will be dispositioned in accordance with regulatory requirements, Hanford Federal Facility Agreement and Consent Order (Tri-Party Agreement) and consent orders, and as funding is applied to the activity per the multi-year work plan (MYWP), or waste will be 
managed compliant with clock limits. A Tri-Party Agreement milestone is an example of work planning.

- Waste pre-existing to implementation of DOE Order 435.1 waste planning, characterization, certification, and packaging requirements [H K, L, M, and O; III, IV H, I, J, and L; and IV N (4)] will be accepted or remain accepted if already received for treatment, storage, or disposal (TSD) under DOE Order $5820.2 \mathrm{~A}$ requirements. No action will be taken to comply with DOE Order 435.1 until the waste proceeds to the next step in management and the activity is required to meet the waste acceptance criteria of the receiving facility. For example, a mixed waste in storage at $\mathrm{CWC}$ before DOE Order 435.1 implementation must meet the acceptance criteria for the LLBG at the time of disposal but does not require evaluation or rework to comply with DOE Order 435.1 requirements for continued storage at CWC. Pre-existing waste will be prepared for disposal as funding allows.

2. Approaches for dealing with identification of the point of generation and staging of newly generated low-level waste include the following.

- Radioactive material and radioactively contaminated material and equipment that are out of service or not being used are considered waste when processed in preparation for TSD. Processing typically involves placement of waste into a container for transport. For example, the processing vessels located in the T Plant Complex cells were flushed and do not contain waste; the vessels are stored as radioactive material and are not waste until action is taken to process the material for disposition as waste.

- The 90-day clock for staging of newly generated post-DOE Order 435.1 low-level waste [IV N(7)] will be implemented per Section 2.2.2 of this document.

- The 90-day staging clock for newly generated waste or TSD staged waste could be extended beyond 90 days with documentation of DOE-RL approval. An extension request should be provided to DOE-RL and include the justification and the length of the extension.

3. Approaches for dealing with the low-level waste TSD facility 90 -day clock for waste staging [IV N(7)] pending acceptance or burial will correspond with requirements applied in accordance with the Resource Conservation and Recovery Act (RCRA) of 1976 permit conditions, including the following.

- Waste will be received and staged for no more than 90 days until the waste is accepted at the receiving facility for treatment or storage or placed for disposal at the LLBG

- The staging clock for placement of waste into high integrity containers (HICs) at the LLBG will be 1 year. A longer staging clock is necessary to allow the collection of enough category 3 waste to campaign the HICs emplacement in a cost-effective manner.

4. Approaches for dealing with the application of the 1 year limit for storage of low-level waste that has a path for disposal [IV N(2)] include the following.

- The storage limit clock will start when the waste is accepted for storage. The acceptance for storage process will correspond with requirements applied in accordance with applicable RCRA permit conditions. The clock will end at the point when the waste is placed in transport to be treated or disposed. The clock is maintained if the waste is transferred to another location for storage. After treatment, if the treated waste is placed in storage, a new clock start date will be established. Mixed 
waste transferred from storage for treatment or disposal will be staged in accordance with the applicable RCRA permit.

- The low-level waste storage limit could be extended beyond 1 year with documentation of DOE-RL approval. An extension request should be provided to DOE-RL and include the justification and the length of the extension.

- The Liquid Waste Processing Facilities (LWPF) will not comply with the low-level waste 1 year storage limit or maintain a clock on waste solutions stored in the Liquid Effluent Retention Facility (LERF). The LERF is used to accumulate and blend waste ranging from several hundreds of gallons to 50 gallons per minute continuous feed streams. Waste in LERF is treated at the 200 Area Effluent Treatment Facility (ETF) in campaigns that process millions of gallons and last several months. Programmatic issues require blending and storage of some waste solutions for longer than the 1 year limit.

- The low-level waste stored at CWC will be stored for the length of time necessary to disposition the waste in accordance to regulatory requirements, performance assessment concerns, Tri-Party Agreement, and consent orders, and as funding is applied to the activity per the MYWP.

5. The existing exemption for use of non-DOE waste treatment provided by DOE-RL to the contractor complies with DOE Order 435.1 requirements [I 2.F(4)]. The exemption, letter 97-SWT-079 dated March 10, 1997, covers the Allied Technology Group (ATG) nonthermal mixed waste treatment contract.

6. Mixed waste will be managed in accordance with a new Hanford Site mixed waste management program, which incorporates compliance with the land disposal restrictions (LDR) imposed by federal and state requirements. The program is described in the annual LDR report, to be issued July 31 , 2000 , which will include the mixed waste program implementation plan, as well as a progress report and the year $2000 \mathrm{LDR}$ report.

7. For activities conducted under the Comprehensive Environmental Response, Compensation, and Liability Act (CERCLA) of 1980, it is assumed that the applicable Record of Decision is the controlling document, such that the requirements of DOE Order 435.1 do not need to be applied if these are substantive requirements of the Manual within the CERCLA remediation boundary. Removal or remediation actions at CERCLA waste sites do not constitute a new activity. These sites are not waste management facilities (in the sense of DOE Order 435.1) and their excavation does not constitute generation or management of waste. The activities of collection, remediation, recovery, digging, etc., of waste material is not a new activity and does not constitute disposal of the material, so the disposal requirements of DOE Order 435.1 do not apply. The new or existing activity is the operation of the receiving facility, the Environmental Restoration Disposal Facility (ERDF), which is subject to the substantive requirements of DOE Order 435.1 .

8. The 'waste incidental to reprocessing' evaluation process (refer to Manual, Chapter II.B) requires a 'necessary and sufficient' determination that management as non-high-level waste adequately is protective. A RCRA permit, where applicable, might be deemed to satisfy this process.

9. Mixed waste managed under CERCLA will be subject only to the substantive requirements of RCRA and Toxic Substances Control Act (TSCA) of 1976.

10. Approaches dealing with segregation of mixed waste from low-level waste [IV N(6)] at the PUREX Storage Tunnels and LWPF include the following. 
- PUREX Storage Tunnels will implement the segregation requirement at the time of waste retrieval. Segregation of waste stored in the PUREX Storage Tunnels is not practical and would not be in accordance with as low as reasonably achievable (ALARA) principles. The existing storage configuration is compliant with RCRA permit conditions and the safety basis, including exemption from inspection requirements.

- LWPF will not implement the segregation requirement for waste solutions in the LERF basins. LERF is used to blend various types of waste for treatment at the 200 Area ETF. The waste undergoes the same treatment and discharge whether the waste is low-level or mixed.

11. The quality assurance requirements for high-level waste found in Chapter Il, Section G and Record Keeping Requirements [I E(14)] apply to the final waste form for disposal at the national repository, not the high-level waste stored or treated at the following facilities: 242-A Evaporator, WESF, and PUREX Storage Tunnels. The treatment or storage of high-level waste at these facilities does not affect the final waste form and acceptance of high-level waste at the national repository.

12. PUREX Storage Tunnels, $183-\mathrm{KW}$ vault, and WESF comply with contingency action (II H, III, and IV E) and confinement systems [II Q(1)] requirements with existing facility and storage configurations. The WESF pool design and operation provide adequate contingency for ruptured capsules and confinement via pools in case of emergencies. The WESF RCRA permit requirements are being developed and will include measures for compliance with contingency actions and confinement systems. PUREX Storage Tunnels design, RCRA permit conditions, and safety basis provide adequate contingency and confinement. The $183-\mathrm{KW}$ vault design and safety basis provide adequate contingency.

13. Inspection of containers of stored waste [III N(3) and IV N(5)] will not occur at the 183-KW vault or PUREX Storage Tunnels. Inspection in these situations is not in accordance with ALARA principles. Storage is compliant without inspection under the safety basis and PUREX Storage Tunnels permit conditions.

14. Waste generated and treated or stored at the facility of generation will employ a graded approach in applying treatment and storage requirements found in DOE Order 435.1. The waste acceptance, waste transfer, and waste certification requirements of the manual (II J, M, and N; III and IV G, J, and $\mathrm{K}$ ) will be implemented appropriately through facility operating procedures developed in compliance with the facility safety basis to govern these operations. Using the graded approach, a high level of documentation formality is not necessary when waste treated or stored does not change organization or facility control.

15. The River Protection Project high-level waste sitewide radioactive waste program as documented in TWRS Systems Engineering Management Plan, HNF-SD-WM-SEMP-002, Rev. 1, includes WESF and 242-A Evaporator in compliance with requirements of Chapter II E.

16. Waste currently received for TSD derived from high-level waste will be evaluated, per the process of Chapter II B, to be Incidental to Reprocessing. The evaluation process and subsequent waste classification will be accomplished before determining the disposition path.

17. WESF stores high-level waste and PUREX Storage Tunnels and 183-KW vault store multiple waste types but will not transfer these waste types out of the facilities until some future time. The waste acceptance, waste transfer, and waste certification requirements of the DOE M 435.1 (II J, M, and N; III and IV G, J, and $\mathrm{K}$ ) will be implemented at the time these waste types are transferred from these facilities in compliance with applicable regulatory requirements. 
18. Compliance with facility design [II P, III and IV M(2)] and packaging [III L(1)(a) and (d) and IV $\mathrm{L}(\mathrm{l})(\mathrm{a})$ and (c)] requirements are accomplished by the implementation of the facility safety basis and permit conditions if appropriate. The safety basis documentation and permits, if appropriate, will be referenced in the RWMB and serve as the document(s) identifying the design and packaging requirements necessary for safe operation, the requirements stated in the manual notwithstanding.

19. The impact of actions taken by DOE to comply with Chapter I Sections $2 \mathrm{~A}$ through $\mathrm{F}$ cannot be determined at this time since these are primarily DOE-HQ responsibilities and no HQ implementation plan has been issued.

20. Existing earthen covered retrievably stored transuranic waste [III N(4)] does not invoke waste storage, design, packaging, and monitoring requirements [III $\mathrm{Q}, \mathrm{N}, \mathrm{L}(1)$, and $\mathrm{M}(2)$ ]. It is not practical or in accordance with ALARA to impose these requirements given the storage configuration.

21. A no path forward waste is one without a route to and/or not possessing a final disposal facility, including either existing facilities or new facility construction that is a line item on the Congressional budget. Those waste types determined to be without a path forward are: non-defense related transuranic, TSCA-regulated transuranic, classified transuranic, transuranic items that cannot be packaged per transuranic packaging transporter (TRUPACT) II requirements, greater-thancategory-3 low-level waste that cannot be demonstrated as compliant for disposal, and mixed waste that does not have a treatment path to disposal. For example, it is assumed that D001 through D003 transuranic waste can be processed by Idaho National Engineering and Environmental Laboratory (INEEL) and remote-handled transuranic waste can be processed by Oak Ridge and thus have a path forward. Plans to manage such waste are needed. The LDR plan (\#6) is an example of such plan.

22. Active LLBG include 218-W-3A, 218-W-4B, 218-W-4C, and 218-W-5; as well as 218-E-10 and 218-E-12B.

23. Compliance with generation, treatment, and storage facility monitoring [II T, III Q and IV R(1) and (2)] and packaging [III L(1)(a) and (d) and IV L(1)(a) and (c)] requirements is accomplished by the implementation of the facility safety basis, permit conditions, and monitoring plan (DOE/RL-91-50, Rev. 2). Safety basis, permit, and monitoring plan documents will be referenced in the RWMB and serve as the documents identifying the monitoring requirements necessary for safe operation, the requirements stated in the manual notwithstanding.

24. For CERCLA actions, the CERCLA process develops a waste management system that incorporates the substantive DOE Order 435.1 requirements as appropriate. Disposal facilities will develop a crosswalk to demonstrate substantive aspects are met.

25. The determination of high activity or high hazard liquid waste [IV E(1)] will be implemented per Section 2.2.1.

26. The waste characterization data quality objective process [II L(1); III; and IV I(1)] for waste treatment processes are satisfied by the facility safety basis and applicable permit conditions. The secondary waste from treatment processes, for example powders from the LWPF liquid treatment process or treatment feed stream waste characterization data quality objective are not satisfied by the treatment facility safety basis and permit conditions.

Work activities to implement DOE Order 435.1 requirements provided as part of this plan, except as specified otherwise, will be scheduled and executed in compliance with regulatory requirements, Tri-Party Agreement, and consent orders, and as funding are applied to the activity per the MYWP. 
Funding to implement DOE Order 435.1 is not identified in fiscal years 2001 and 2002 budgets. This document provides implementation work scope, cost to execute, and elapsed time to complete in support of budget and work authorization processes.

\subsubsection{Determination of High Activity and High Hazard Low-Level Liquid Waste Pursuant to DOE Manual 435.1-1 Chapter IV E(1)}

Certain contingency measures are required by the DOE Manual 435.1-1, Chapter IV, Section E(1) for "high activity or high hazard liquid low-level waste storage or treatment". High activity or high hazard liquid is waste that poses a potential impact to large numbers of onsite and offsite persons. Existing DOE safety programs under DOE Order 5480.23 as implemented by DOE-STD-1027-92 evaluate these potentials and forms the basis of the determination of whether a liquid is high activity or high hazard waste or not.

The definition of high activity or high hazard liquid waste under DOE Order 435.1 is equivalent to a Hazard Category 2 facility classification under DOE Order 5480.23 as implemented by DOE-STD-1027-92. So a high activity or high hazard low-level liquid waste is waste that would cause a facility to be classified as a Hazard Category 2 or 1 facility. In determining if the liquid is the basis of the facility categorization, facility segmentation (as identified in the DOE guidance documents DOE-STD-1027-92 and DOE-EM-STD-5502-94) will be employed.

In some case where a final facility hazard category has not been determined, an initial hazard classification will be performed until a final classification can be provided. The initial hazard classification will be determined per Section 2.1.2 of HNF-PRO-704 or an equivalent process.

\subsubsection{Implementation of 90-Day Staging Clock for Newly Generated Low-Level Waste}

This discussion describes the implementation of the DOE Order 435.1 requirement of less than 90-day staging time limit of low-level waste. As used in this section, the following terms have different meaning than those in the Glossary.

- Generator: Operator of the facility who generates low-level waste during cleanup, upgrade, surveillance, monitoring, or maintenance activities.

- Container: Any container used to accumulate waste for transport, e.g., drum, box, plastic bag, or plastic wrapped item.

- Full Container: Container considered full per manufacturer, safety analysis report, or operating procedures as appropriate.

Generators are to accumulate low-level waste and transport the waste to a TSD unit within 90 days from the start of the staging clock. The staging date is established when the container is full or no longer needed. Waste can be collected in various size containers that meet the needs of generators. There will be no volume restriction. The volume will be limited to the size of the container only.

The generator will have the choice either to set up a container at each generation point to collect the waste or set up a centralized collection point where the waste will be collected from all the generating points and placed in containers. This is to meet the generators needs, to be cost effective, and to meet the waste minimization requirements. When a container is full or no longer needed, the 90 -day staging clock start date is established. The generator will have 90 days to complete the characterization and transport the 
container to a TSD unit. For large size items that do not fit in a container and will be transported under the flexible material safety analysis report for packaging, the staging clock start date is established when processing is initiated to prepare the item for disposition as waste. At that point, the generator has 90 days to transport the waste. The 90-day staging clock ends when the container is placed in transport to a TSD unit.

The 90-day staging time limit is applied to a container of waste, as classification is accomplished on a container basis, rather than to the waste components inside the container. During repackaging, if a waste item is removed and packaged into a different container, the start date of the 90-day staging clock for the new container will be when the container is full or no longer needed.

For bulk low-level waste, the 90-day staging clock start date will be established when the generator has a quantity of waste that can be transported or the activity generating the waste is completed. The quantity of waste to be transported will be determined on a case-by-case basis.

In cases where a waste package is reclassified due to repackaging, change in characterization, etc., the 90-day staging clock start date will be applied to the container as the date the reclassification determination was made without regard to the previous start date. If a waste package is not accepted and returned for further treatment, a new 90-day clock starts when the waste is treated and repackaged for retransport.

PNNL will develop procedures for staging their low-level waste that are consistent with the procedures for managing hazardous waste in less-than-90-day accumulation areas. The details of the plan for staging low-level waste will be documented in the PNNL RWMB.

\subsection{SIGNIFICANT IMPACTS AND ACTIONS}

The new requirements are concentrated in the following few major areas. These areas contain the major costs associated with implementing the DOE Order 435.1.

1. The RWMB is required for all facilities that manage radioactive waste, and covers all activities required to meet the requirements of DOE Order 435.1 and the Manual. RWMB provides the safety and environmental basis for facility operations, and is quite similar to the $A E$ required by HNF-PRO-2701 to satisfy the requirements of HNF-MP-003. Thus, the RWMB should reference the $\mathrm{AE}$ and key safety and environmental documents (including permits), monitoring plans (including the general sitewide monitoring plan), performance assessments, disposal authorization statements, and any other documentation that provides the basis for concluding that the facility can operate with an appropriate level of protection for the public, workers, and the environment. The RWMB, as defined in DOE M 435.1, also contains a few additional specific items, including storage and staging of waste, generator characterization and certification requirements, waste acceptance criteria for facilities receiving waste for TSD, procedure for designating waste as 'incidental', life-cycle planning, workoff plans for existing waste, and closure plans for disposal facilities. To the extent that these requirements are met by other documentation, the RWMB should incorporate these by reference. $A$ detailed crosswalk against the specific manual requirements is not needed. Instead, the RWMB should include a statement that the referenced documents provide the appropriate basis for operations.

Every facility will need a RWMB. It is expected that the RWMBs for many facilities could be addressed in a single document to reduce the cost and complexity of this effort. This will be considered in the implementation process. 
2. Staging ( 90 day) and storage (1 year) limits are established to ensure that waste is characterized, packaged, and stored properly. All waste generators must evaluate staging and storage conditions for compliance.

3. 'Waste incidental to reprocessing' might be managed as transuranic or low-level waste, if so determined by citation or evaluation, and an adequate level of safety established for disposal other than in a geologic repository. Those determinations by evaluation will require appropriate safety analyses.

4. Waste generators will need to have a planning process to ensure that requirements for characterization, handling, certification, and disposal can be met before new waste is generated. This is basically the life cycle asset management process applied to all waste management facilities.

5. Many older facilities (including, but not limited to, the PUREX Storage Tunnels) do not meet modern siting, design, engineering and operational requirements. It would not be cost effective to attempt to upgrade such facilities, and remediation already could be planned or in progress. Nevertheless, substantial procedural, administrative, analytical, and reporting requirements are added by the Manual that might be costly to implement, even without the upgrades.

6. Added requirements for characterization, packaging, storage, certification, operations, monitoring, and disposal all involve substantial additional costs. Some of these costs appear as modifications to documents (such as waste acceptance criteria, procedures, program plans, certification plans, training plans, materials, and others), or new documents for similar purposes, but the costs include additional actions required as well as the revision costs for the documents.

7. Documentation and records requirements are expanded, including the data quality objective process.

8. Contingency and corrective action planning requirements are extensive and expensive.

9. Extensive monitoring requirements are established. Many parameters are specified that require additional equipment, unless exempted by a specific justification with comparison to the safety basis for the facility and existing monitoring plan. New equipment and justifications will add costs.

\subsection{COSTS}

Cost estimates developed for the actions identified in the IP, where possible, are listed in the Appendix. Costs are not included for compliance with DOE Orders not currently included in contracts or for actions that could result from future DOE actions required by DOE Order 435.1, as those actions and costs currently are unknown (i.e., these might result from DOE-HQ actions). Many of the costs involve revising existing documents, procedures, and training plans. To the degree possible, the new requirements will be added as part of the normal revision cycle for those documents, rather than doing separate revisions for DOE Order 435.1. Costs cited are for the additional efforts required for the revisions, as well as the costs of compliance with the added requirements. Total cost estimate is approximately $\$ 2.1$ million.

Funding sources for these costs have not been identified, although new funding or displacement (or rescheduling) of current scope (by DOE directions) are possible sources. Thus, the time for implementing each requirement is listed as elapsed time after funding is provided, rather than providing a specific completion date. For a few items (noted in the Appendix), the activity already is funded and a completion date is given. Some substantial potential costs have been eliminated by providing appropriate 
assumptions or interpretations (Section 2.2), with explanations to justify the exceptions taken. If these interpretations are found to be inappropriate, substantial additional costs could be incurred.

\subsection{IMPLEMENTATION PLAN MAINTENANCE}

The requirements of this IP will be reviewed annually and revised whenever justified by substantive changes. The IP changes will be documented and approved. 
DOE/RL-2000-25, Rev. 1

$06 / 2000$

This page intentionally left blank. 
Table 2-1. DOE Orders and Directives Listed in DOE Order 435.1.

\begin{tabular}{|c|c|c|c|c|c|}
\hline \multirow{2}{*}{ DOE Directive } & \multirow{2}{*}{ Title } & \multicolumn{3}{|c|}{ Contract } & \multirow{2}{*}{ Comment } \\
\hline & & $\mathrm{FH}$ & PNNL & BHI & \\
\hline DOE 4330.4B & $\begin{array}{l}\text { Maintenance Management } \\
\text { Program }\end{array}$ & $\mathrm{Y}$ & $\mathrm{Y}$ & $\mathrm{Y}$ & \\
\hline $\begin{array}{l}\text { DOE } 400.111 / 09 / 88 \\
\text { Change } 106 / 29 / 90\end{array}$ & $\begin{array}{l}\text { General Environmental } \\
\text { Protection Program }\end{array}$ & $\bar{Y}$ & $\mathrm{Y}$ & $\mathrm{Y}$ & $\begin{array}{l}\text { (Chapter II 2B, 4B, and } 4 \mathrm{C} \text { and } \\
\text { Chapter III 2D and } 3 \mathrm{~B} \text { cancelled by } \\
\text { DOE Order } 231.1 \text { ) }\end{array}$ \\
\hline $\begin{array}{l}\text { DOE } 5400.502 / 08 / 90 \\
\text { Change } 106 / 06 / 90 \\
\text { Change } 201 / 07 / 93\end{array}$ & $\begin{array}{l}\text { Radiation Protection of the } \\
\text { Public and the Environment }\end{array}$ & $\bar{Y}$ & $\bar{Y}$ & $\bar{Y}$ & $\begin{array}{l}\text { (Chapter II } 1 \mathrm{~A}(3)(\mathrm{A}) \text { cancelled by } \\
\text { DOE Order } 231.1)\end{array}$ \\
\hline DOE 5480.21 & & $\mathrm{~N}$ & $\mathrm{~N}$ & $\mathrm{~N}$ & \\
\hline DOE $5480.1907 / 09 / 90$ & $\begin{array}{l}\text { Conduct of Operations } \\
\text { Requirements for DOE } \\
\text { Facilities }\end{array}$ & $\mathrm{Y}$ & $\bar{N}$ & $\bar{Y}$ & Currently not in PNNL contract \\
\hline DOE $5480.20 \mathrm{~A} 11 / 15 / 94$ & $\begin{array}{l}\text { Personnel Selection, } \\
\text { Qualification, and Training } \\
\text { Requirements for DOE Nuclear } \\
\text { Facilities }\end{array}$ & $\bar{Y}$ & $\bar{Y}$ & $\bar{Y}$ & \\
\hline $\begin{array}{l}\text { DOE } 5480.2202 / 25 / 92 \\
\text { Change } 109 / 15 / 92 \\
\text { Change } 201 / 23 / 96\end{array}$ & Technical Safety Requirements & $\bar{Y}$ & $\bar{Y}$ & $\bar{Y}$ & $\begin{array}{l}\text { (Cancels } 5 \mathrm{~h}, 7 \mathrm{e}(4) \text {, and } 8 \mathrm{~d} \text { DOE Order } \\
5480.5 ; \text { paras } 5 \mathrm{v}, 7 \mathrm{e}(4) \text { and } 8 \mathrm{~d} \text { of DOE } \\
\text { Order } 5480.6)\end{array}$ \\
\hline $\begin{array}{l}\text { DOE } 5480.2304 / 10 / 92 \\
\text { Change } 103 / 10 / 94\end{array}$ & $\begin{array}{l}\text { Nuclear Safety Analysis } \\
\text { Reports }\end{array}$ & $\bar{Y}$ & $\mathrm{Y}$ & $\mathrm{Y}$ & $\begin{array}{l}\text { Cancels DOE Order } 5481.1 \mathrm{~B} \text { (nuclear } \\
\text { facility only); para } 7 \mathrm{~b}(3), 7 \mathrm{e}(3), 8 \mathrm{c} \text { of } \\
\text { DOE Order } 5480.6 \text {; para } 51,7 \mathrm{~b}(3) \text { and } \\
\text { (4), } 7 \mathrm{e}(3), 8 \mathrm{a}, \ldots\end{array}$ \\
\hline$\overline{\mathrm{DOE}} 5632.1 \mathrm{C} 07 / 15 / 94$ & $\begin{array}{l}\text { Protection and Control of } \\
\text { Safeguards and Security } \\
\text { Interests }\end{array}$ & $\mathrm{Y}$ & $\bar{Y}$ & $\bar{Y}$ & \\
\hline DOE 5633.3B 09/07/94 & $\begin{array}{l}\text { Control and accountability of } \\
\text { Nuclear Materials }\end{array}$ & $\mathrm{N}$ & $\bar{Y}$ & $\mathrm{~N}$ & $\begin{array}{l}\text { Cancelled by DOE Order } 474.1 \\
09 / 11 / 99 \text { same title. Deleted from all } \\
\text { but PNNL contracts. }\end{array}$ \\
\hline DOE M 251.1-1A 01/30/98 & Directives System Manual & $\mathrm{N}$ & $\hat{N}$ & $\mathrm{~N}$ & $\begin{array}{l}\text { Guidance for DOE in the preparation } \\
\text { of DOE documents does not apply to } \\
\text { contractors. }\end{array}$ \\
\hline DOE M 4/1.1-1 10/08/97 & $\begin{array}{l}\text { Safety management Functions, } \\
\text { Responsibilities and } \\
\text { Authorities Manual }\end{array}$ & $\mathbf{N}$ & $\overline{\mathrm{N}}$ & $\mathrm{N}$ & $\begin{array}{l}\text { Applies to DOE only; replaced by } \\
\text { DOE M } 411.1-1 \text { A } 10 / 18 / 99\end{array}$ \\
\hline DOE M 450.3-1 01/25/96 & $\begin{array}{l}\text { The Department of Energy } \\
\text { Closure Process for Necessary } \\
\text { and Sufficient Sets of } \\
\text { Standards }\end{array}$ & $\mathrm{N}$ & $\bar{Y}$ & $\mathrm{~N}$ & \\
\hline $\begin{array}{l}\text { DOE O } 151.109 / 25 / 95 \\
\text { Change } 110 / 26 / 95 \\
\text { Change } 208 / 21 / 96\end{array}$ & $\begin{array}{l}\text { Comprehensive Emergency } \\
\text { Management System }\end{array}$ & $\bar{Y}$ & $\bar{Y}$ & $\bar{Y}$ & \\
\hline DOE O $200.109 / 30 / 96$ & $\begin{array}{l}\text { Information Management } \\
\text { System }\end{array}$ & $\mathrm{N}$ & $\bar{N}$ & $\overline{\mathrm{N}}$ & $\begin{array}{l}\text { This order has a contractor } \\
\text { requirements document and could be } \\
\text { implemented in all contracts if desired. }\end{array}$ \\
\hline $\begin{array}{l}\text { DOE O } 210.109 / 27 / 95 \\
\text { Change } 110 / 26 / 95 \\
\text { Change } 205 / 01 / 96\end{array}$ & $\begin{array}{l}\text { Performance Indicators and } \\
\text { Analysis of Operations } \\
\text { Information }\end{array}$ & $\mathrm{N}$ & $\mathrm{N}$ & $\mathrm{N}$ & $\begin{array}{l}\text { The contractor requirements document } \\
\text { for this document calls for actions by } \\
\text { the contractor and could be } \\
\text { implemented in the contracts if } \\
\text { desired. }\end{array}$ \\
\hline $\begin{array}{l}\text { DOE O } 231.109 / 30 / 95 \\
\text { Change } 110 / 26 / 95 \\
\text { Change } 211 / 07 / 96\end{array}$ & $\begin{array}{l}\text { Environment, Safety, and } \\
\text { Health Reporting }\end{array}$ & $\mathrm{N}$ & $\bar{Y}$ & $\mathrm{~N}$ & $\begin{array}{l}\text { Para } 5 \mathrm{~B}(2) \text { cancelled by DOE Order } \\
470.2 \mathrm{~A} \text {. Contractor requirements are } \\
\text { covered under DOE Order } 232.1 \mathrm{~A} \text {. }\end{array}$ \\
\hline DOE O 232.1A $07 / 21 / 97$ & $\begin{array}{l}\text { Occurrence Reporting and } \\
\text { Processing of Operations } \\
\text { Information }\end{array}$ & $\mathrm{Y}$ & $\mathrm{Y}$ & $\mathrm{Y}$ & \\
\hline DOE O $360.109 / 21 / 99$ & Federal Employee Training & $\mathrm{N}$ & $\mathrm{N}$ & $\overline{\mathrm{N}}$ & Applies to federal employees only. \\
\hline DOE O $414.111 / 24 / 98$ & Quality Assurance & $\mathrm{Y}$ & $\mathrm{Y}$ & $\mathrm{N}$ & \\
\hline
\end{tabular}


Table 2-1. DOE Orders and Directives Listed in DOE Order 435.1.

\begin{tabular}{|c|c|c|c|c|c|}
\hline \multirow{2}{*}{ DOE Directive } & \multirow{2}{*}{ Title } & \multicolumn{3}{|c|}{ Contract } & \multirow{2}{*}{ Comment } \\
\hline & & FH & PNNL & BHl & \\
\hline $\begin{array}{l}\text { DOE O } 420 . \overline{10 / 13 / 95} \\
\text { Change } 111 / 16 / 95 \\
\text { Change } 210 / 24 / 96\end{array}$ & Facility Safety & $\mathrm{N}$ & $\mathrm{N}$ & $\mathrm{N}$ & $\begin{array}{l}\text { Detailed contractor requirements } \\
\text { document provided. }\end{array}$ \\
\hline DOE O $425.1 \mathrm{~A} 12 / 28 / 98$ & $\begin{array}{l}\text { Startup and Restart of Nuclear } \\
\text { Facilities }\end{array}$ & $\mathrm{Y}$ & $\bar{Y}$ & $\overline{\mathbf{N}}$ & $\begin{array}{l}\text { Implemented on FH and PNNL } \\
\text { contracts March } 30,2000 \text {. Contractor } \\
\text { requirements document needs tailoring } \\
\text { for DOE-RL-specific requirements. }\end{array}$ \\
\hline DOE O 430.1A $10 / 14 / 98$ & Life Cycle Asset Management & $\mathrm{N}$ & $\mathbf{N}$ & $\bar{N}$ & \\
\hline DOE O $440.1 \mathrm{~A} 03 / 27 / 98$ & $\begin{array}{l}\text { Worker Protection } \\
\text { Management for DOE Federal } \\
\text { and Contractor Employees }\end{array}$ & $\mathrm{N}$ & $\mathrm{N}$ & $\mathrm{N}$ & \\
\hline$\overline{D O E ~ O ~} 451.1 \mathrm{~A} \mathrm{06/06/97}$ & $\begin{array}{l}\text { National Environmental Policy } \\
\text { Act Compliance Program }\end{array}$ & $\mathrm{N}$ & $\mathrm{Y}$ & $\mathrm{N}$ & $\begin{array}{l}\text { Implemented in PNNL contract where } \\
\text { it should not be. Order specifically } \\
\text { says not applicable to contractors, } \\
\text { federal responsibility only. }\end{array}$ \\
\hline DOE O $460.1 \mathrm{~A} 10 / 02 / 96$ & $\begin{array}{l}\text { Packaging and Transportation } \\
\text { Safety }\end{array}$ & $\bar{Y}$ & $\mathrm{Y}$ & $\mathrm{N}$ & \\
\hline $\begin{array}{l}\text { DOE O } 460.209 / 27 / 95 \\
\text { Change } 110 / 26 / 95\end{array}$ & $\begin{array}{l}\text { Departmental Materials } \\
\text { Transportation and Packaging } \\
\text { Management }\end{array}$ & $\bar{Y}$ & $\overline{\mathrm{Y}}$ & $\mathrm{Y}$ & \\
\hline $\begin{array}{l}\text { DOE O } 470.109 / 28 / 95 \\
\text { Change } 106 / 28 / 96\end{array}$ & $\begin{array}{l}\text { Safeguards and Security } \\
\text { Program }\end{array}$ & $\bar{Y}$ & $\mathrm{Y}$ & $\bar{N}$ & \\
\hline DOE O $5480.2112 / 24 / 91$ & Unreviewed Safety Questions & $\mathrm{Y}$ & $\mathrm{Y}$ & $\mathrm{Y}$ & \\
\hline DOE P $450.301 / 25 / 96$ & $\begin{array}{l}\text { Authorizing Use of the } \\
\text { Necessary and Sufficient } \\
\text { Process for Standards-based } \\
\text { Environmental, Safety and } \\
\text { Health Management }\end{array}$ & $\mathrm{N}$ & $\mathrm{N}$ & $N$ & Applicable to DOE, not contractors \\
\hline DOE P $450.410 / 15 / 96$ & $\begin{array}{l}\text { Safety Management System } \\
\text { Policy }\end{array}$ & $\mathrm{N}$ & $\mathrm{N}$ & $\mathrm{N}$ & Applicable to DOE, not contractors \\
\hline DOE P $450.506 / 26 / 97$ & $\begin{array}{l}\text { Line Environmental, Safety and } \\
\text { Health Oversight }\end{array}$ & $\mathrm{N}$ & $\mathrm{N}$ & $\mathrm{N}$ & Applicable to DOE, not contractors \\
\hline DOE-EM-STD-5502 & & $\mathrm{N}$ & $\mathrm{N}$ & $\mathrm{N}$ & $\begin{array}{l}\text { Standards are not contractual } \\
\text { requirements; are for guidance only }\end{array}$ \\
\hline DOE-STD-1027-92 & & $\mathbf{N}$ & $\overline{\mathrm{N}}$ & $\mathbf{N}$ & $\begin{array}{l}\text { Standards are not contractual } \\
\text { requirements; are for guidance only }\end{array}$ \\
\hline Exec Order 12856 & & $\mathbf{N}$ & $\mathrm{N}$ & $N$ & $\begin{array}{l}\text { Issued } 08 / 03 / 93 ; \text { required to be } \\
\text { implemented in federal acquisition } \\
\text { requirement within } 24 \text { months. } \\
\text { Covered in a federal acquisition } \\
\text { requirement clause not in directives } \\
\text { list. }\end{array}$ \\
\hline Exec. Order 13101 & & $\overline{\mathrm{N}}$ & $\mathrm{N}$ & $\mathrm{N}$ & $\begin{array}{l}\text { Issued } 09 / 14 / 98 \text { to be in federal } \\
\text { acquisition requirement within } 180 \\
\text { days. Covered in a federal acquisition } \\
\text { requirement clause not in directives } \\
\text { list. }\end{array}$ \\
\hline $\mathrm{RU}-033 \mathrm{P}$ & $\begin{array}{l}\text { Quality Assurance } \\
\text { Requirements and Descriptions }\end{array}$ & $\mathrm{N}$ & $\mathrm{N}$ & $\mathrm{N}$ & $\begin{array}{l}\text { Standards are not contractual } \\
\text { requirements: are for guidance only. }\end{array}$ \\
\hline I)( )E: E:M-0093 & & $\mathbf{N}$ & $\mathrm{N}$ & $\mathbf{N}$ & $\begin{array}{l}\text { Standards are not contractual } \\
\text { requirements; are for guidance only. }\end{array}$ \\
\hline $\mathrm{DCH} / \mathrm{RW}-0351 \mathrm{P}$ & & $\mathbf{N}$ & $\mathrm{N}$ & $\bar{N}$ & $\begin{array}{l}\text { Standards are not contractual } \\
\text { requirements; are for guidance only. }\end{array}$ \\
\hline
\end{tabular}


DOE/RL-2000-25, Rev. 1

\section{APPENDIX A}

DOE ORDER 435.1 IMPLEMENTATION PLAN 
DOE/RL-2000-25, Rev. 1

$06 / 2000$

This page intentionally left blank. 
DOE/RL-2000-25, Rev. 1

$06 / 2000$

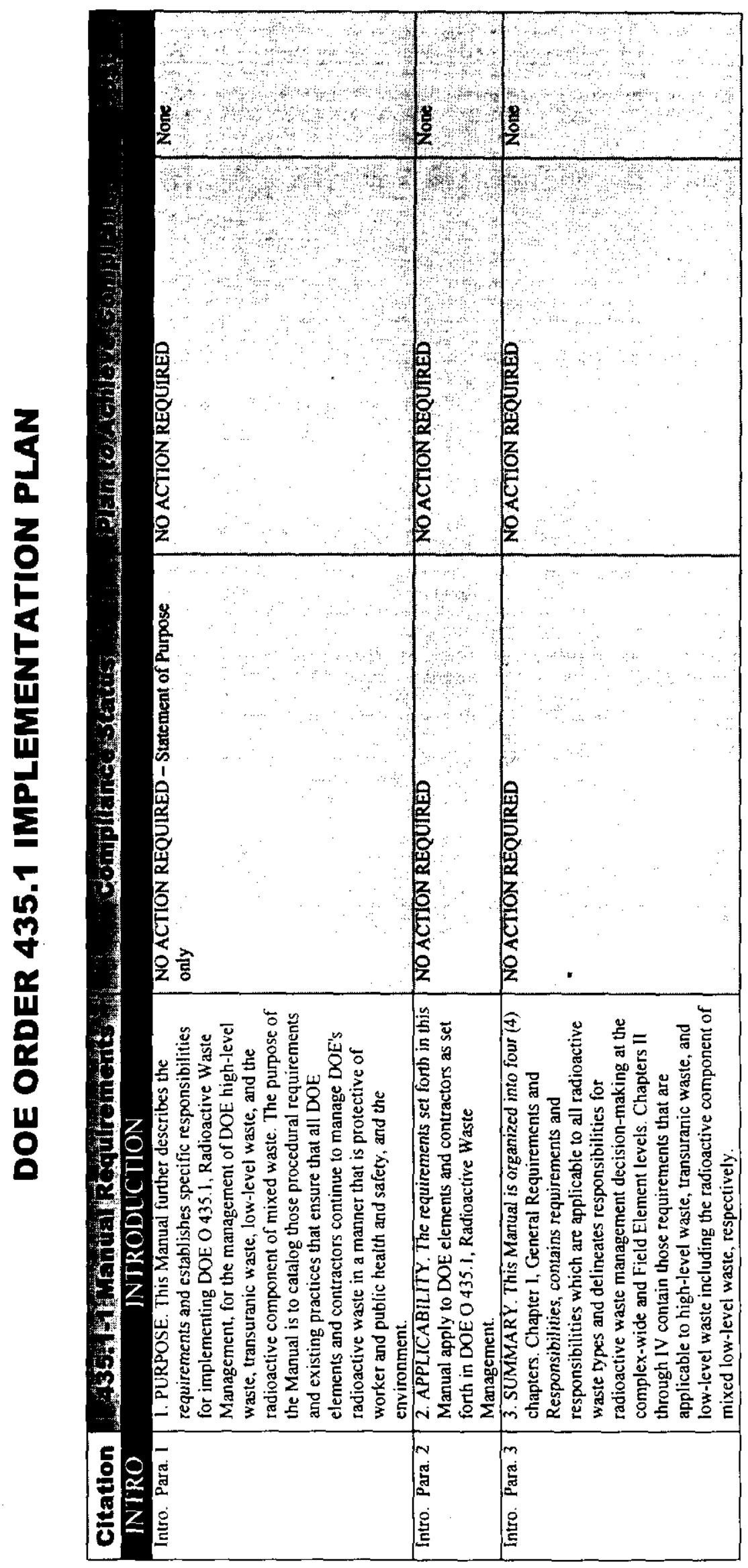

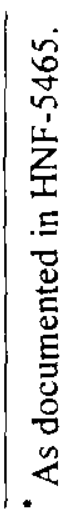




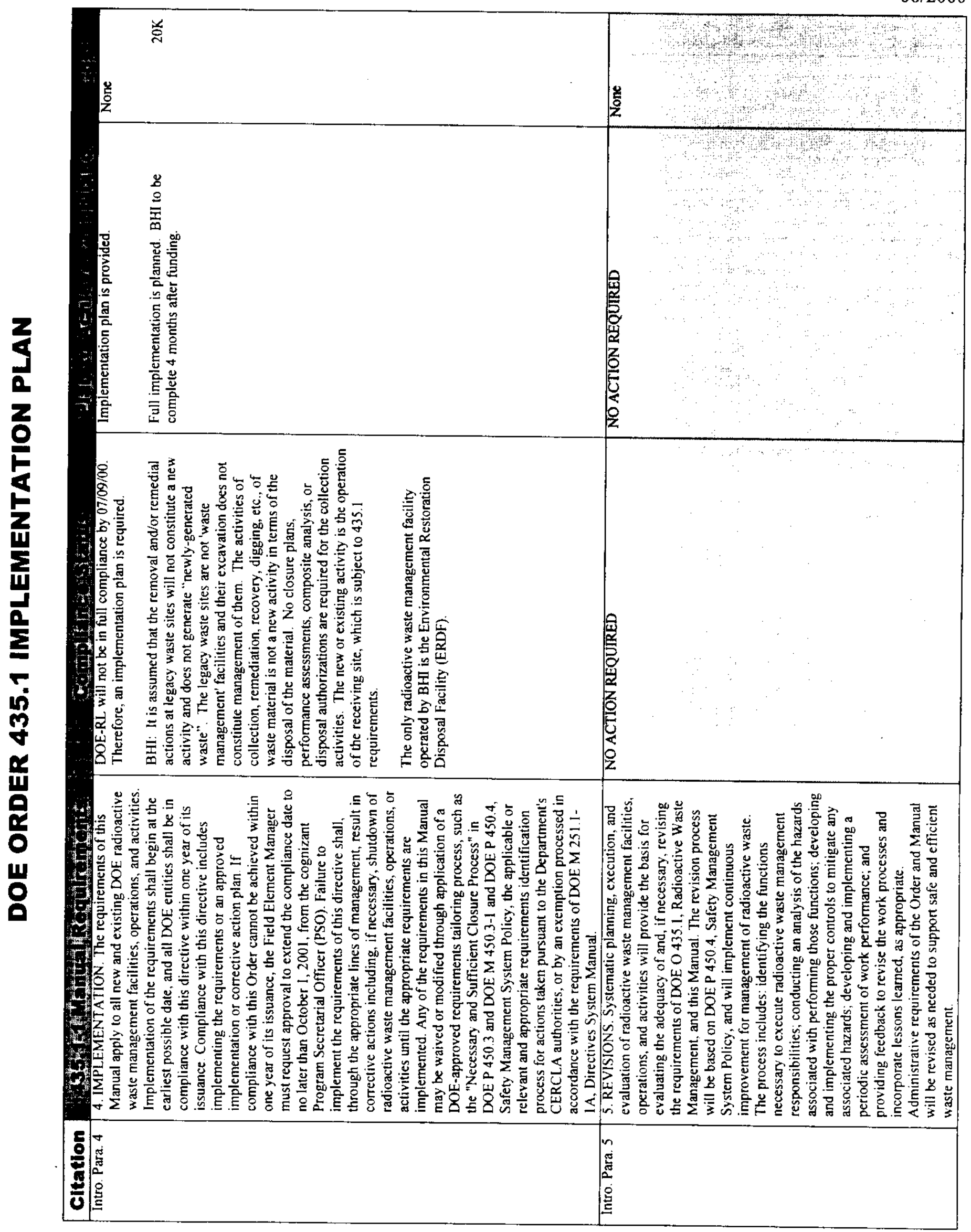


DOE/RL-2000-25, Rev. 1 $06 / 2000$

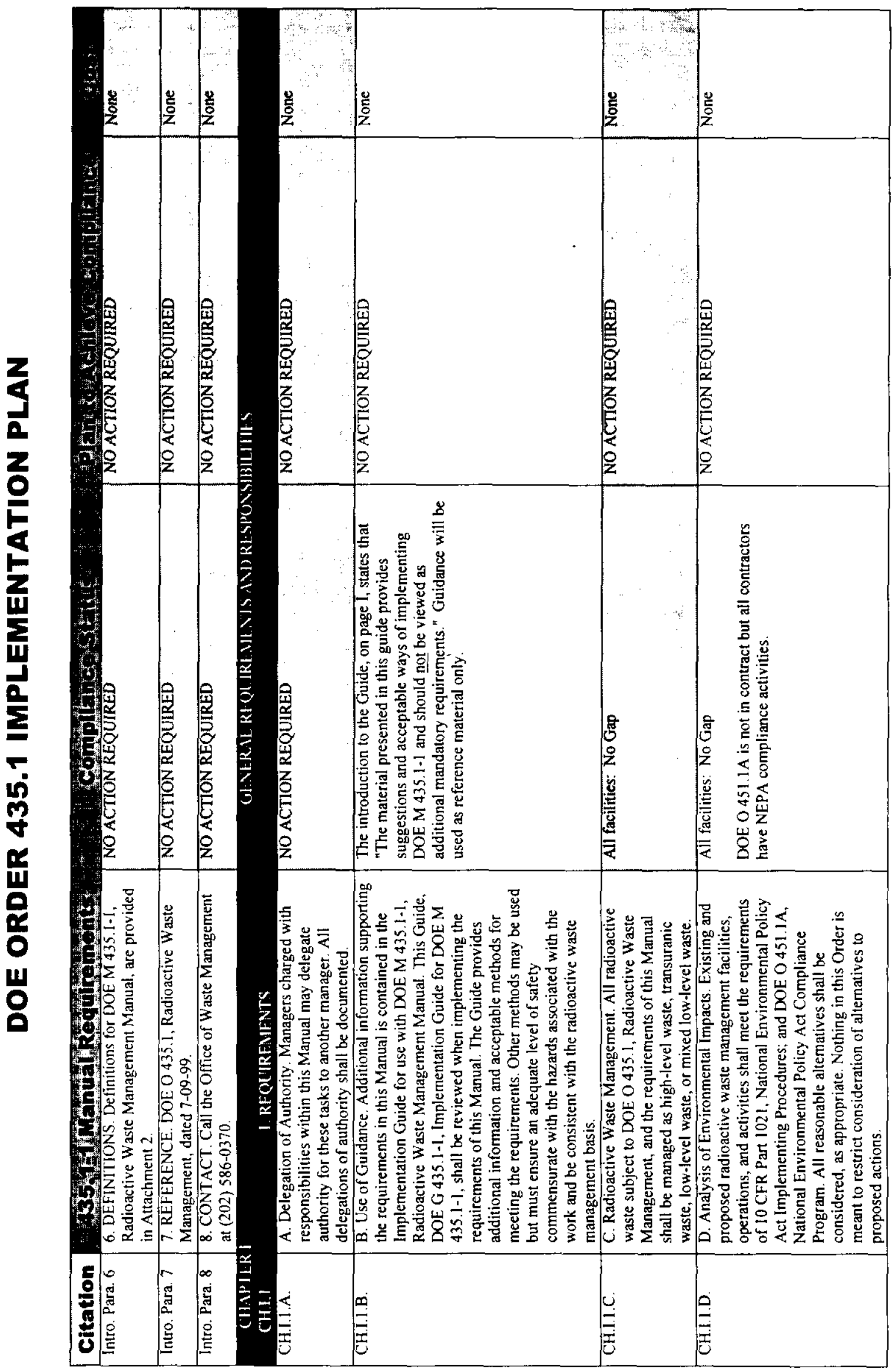


DOE/RL-2000-25, Rev. 1

$06 / 2000$

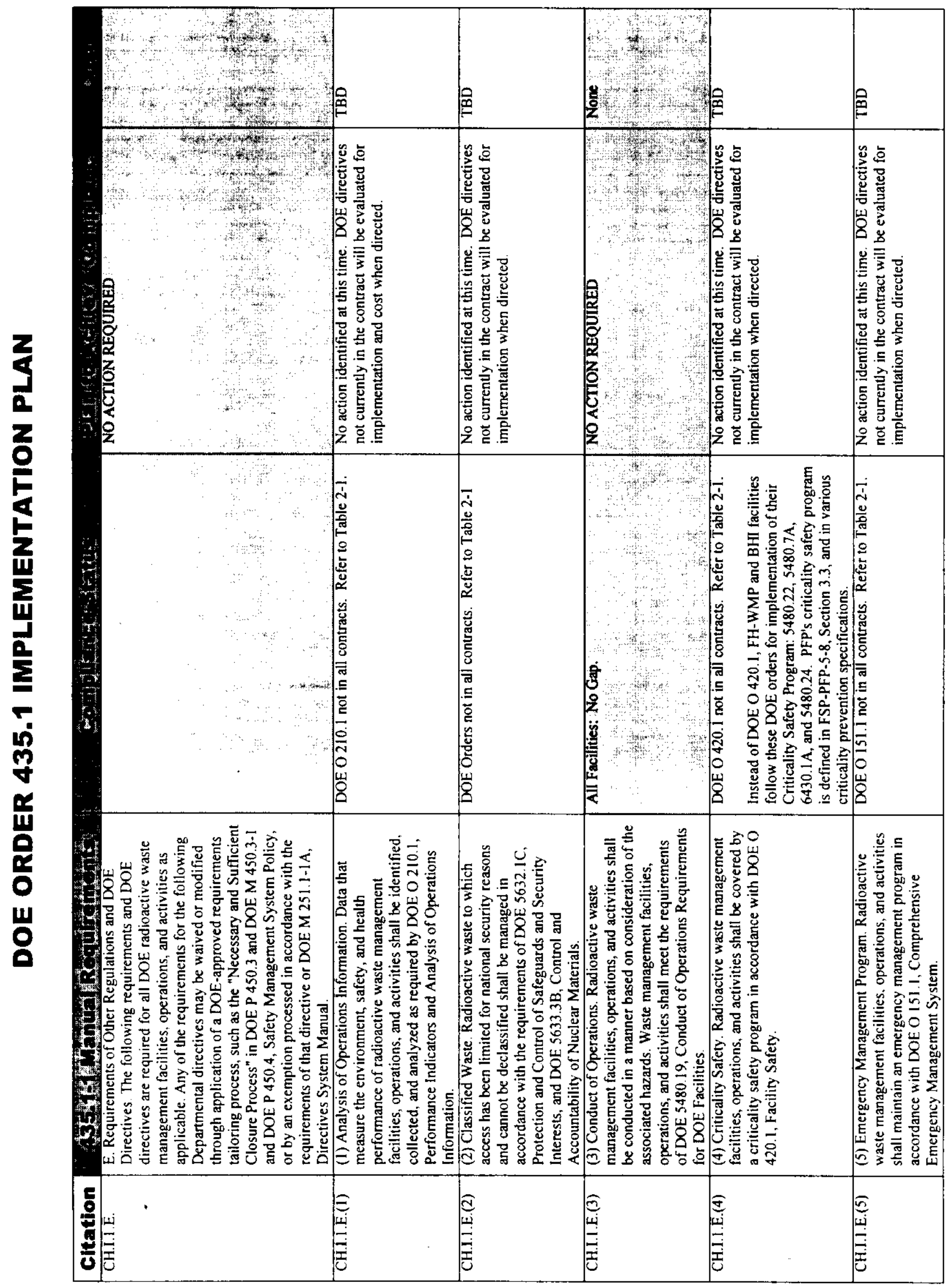




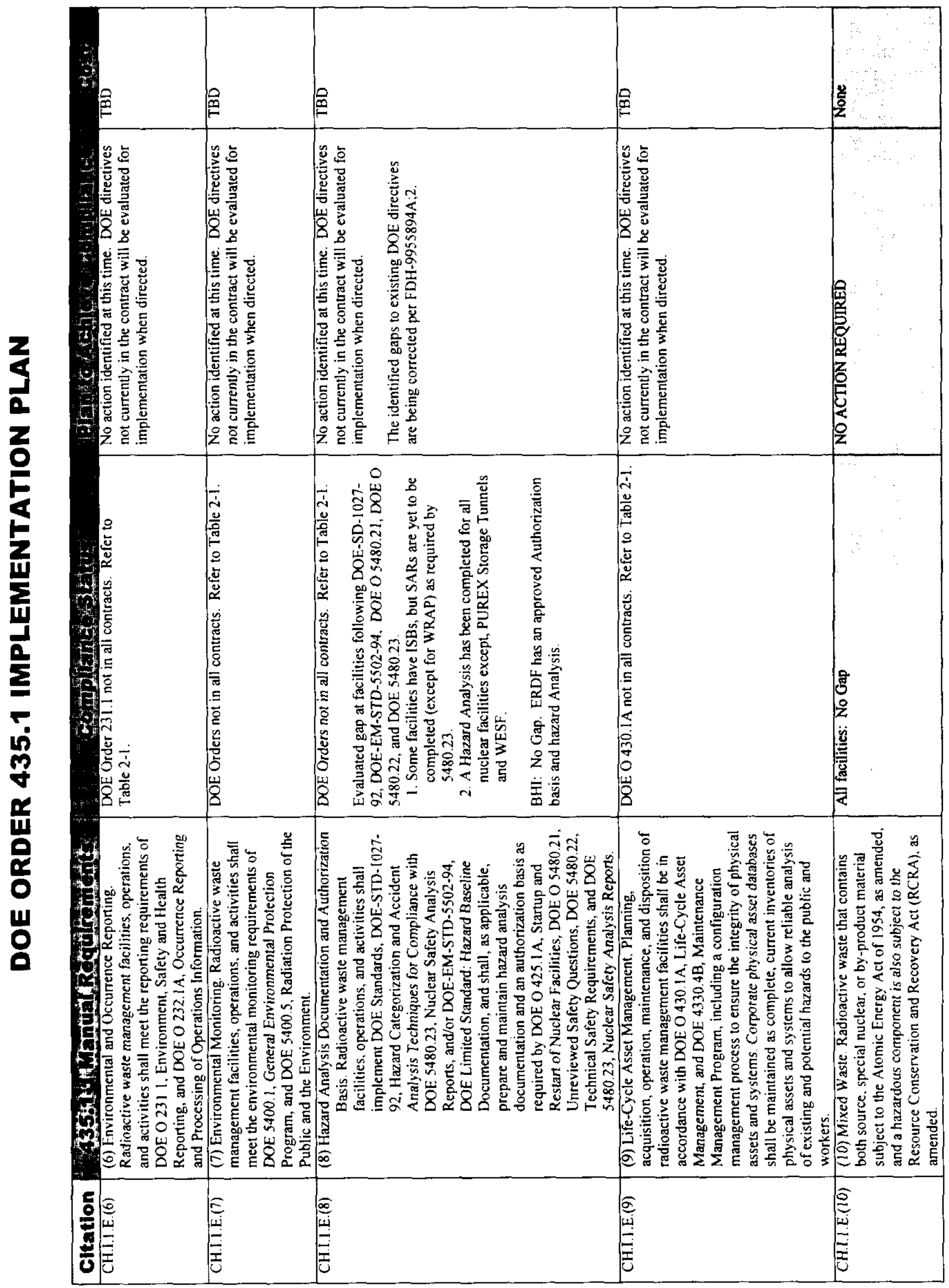


DOE/RL-2000-25, Rev. 1

$06 / 2000$

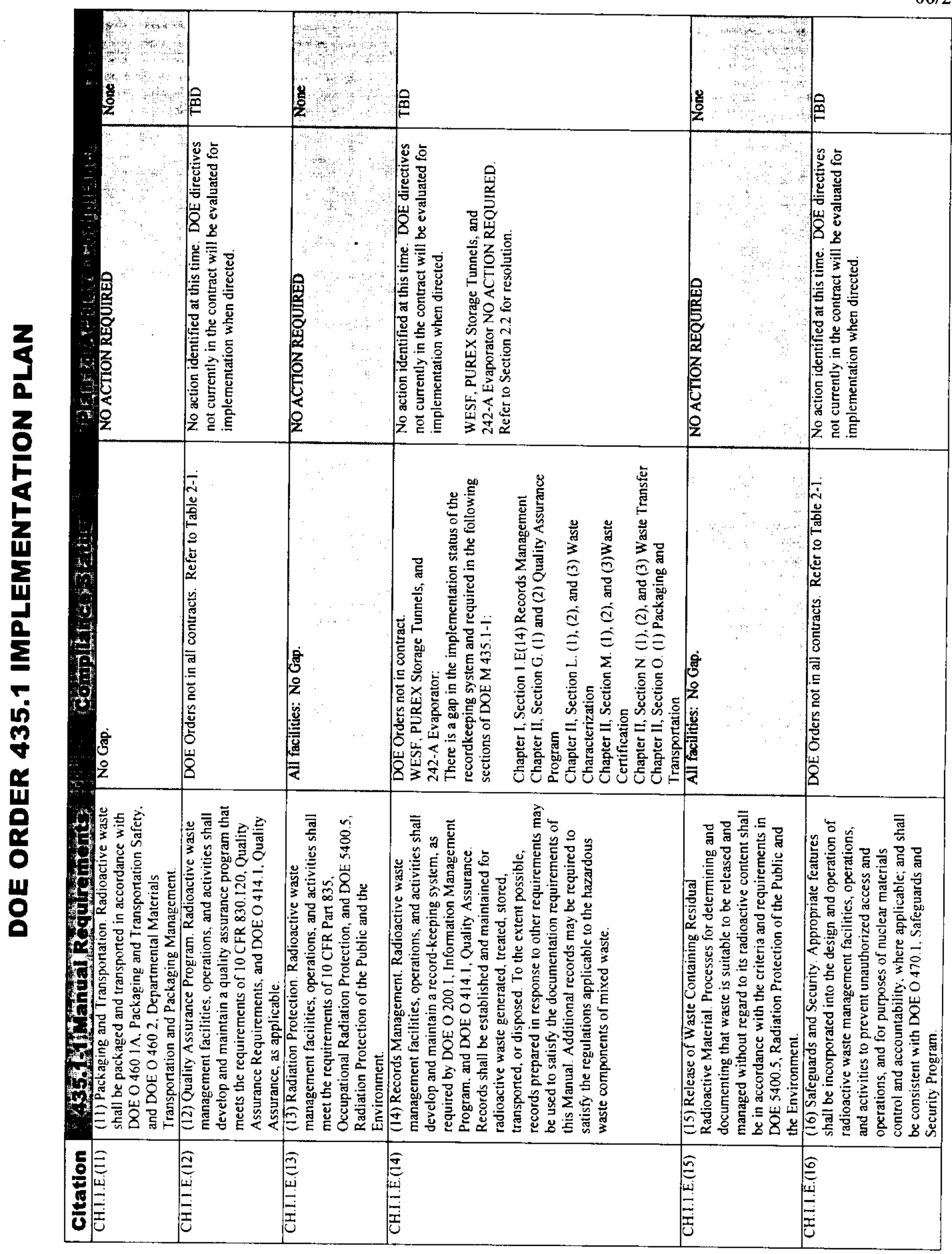


DOE/RL-2000-25, Rev. 1

$06 / 2000$

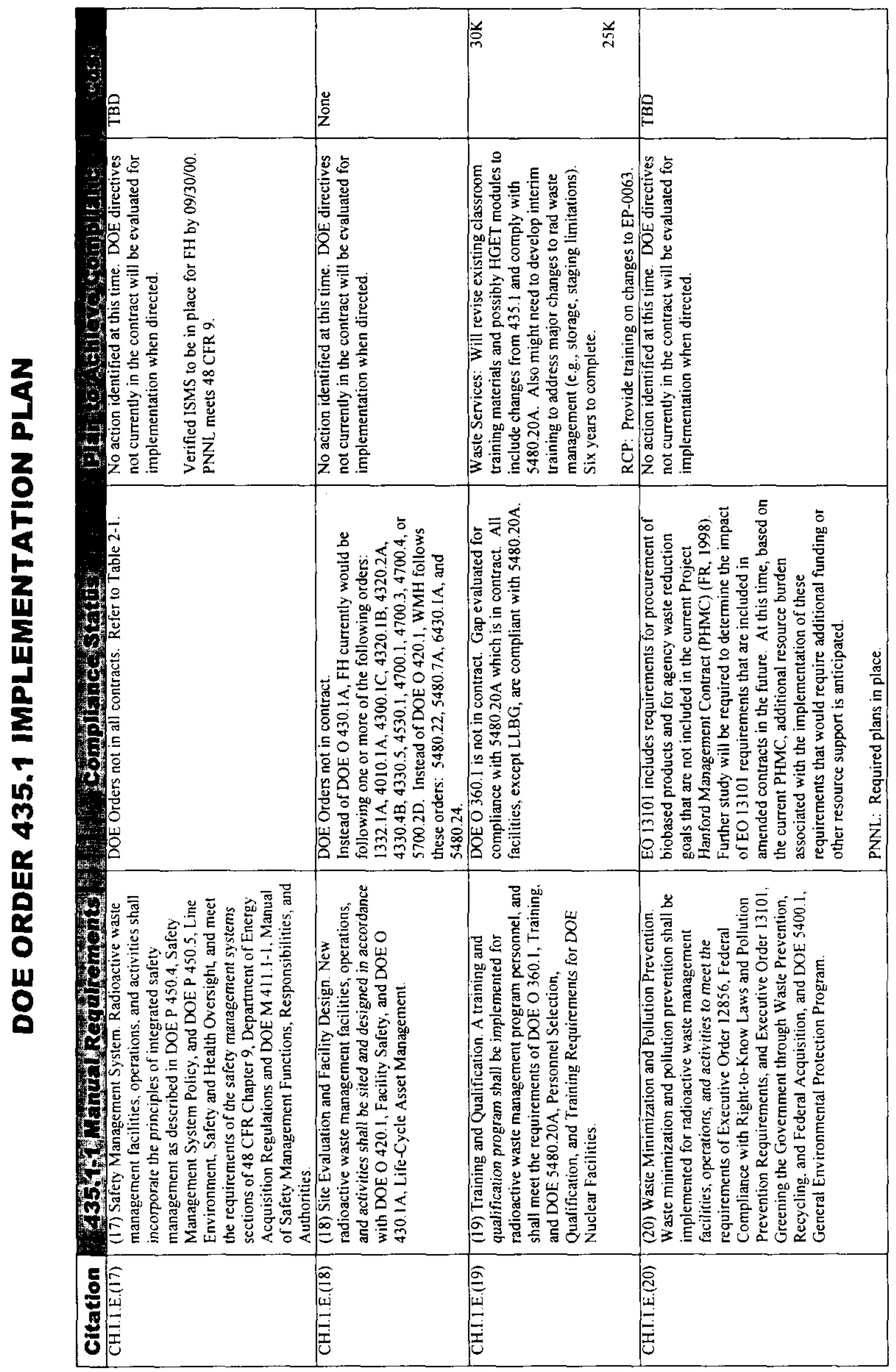




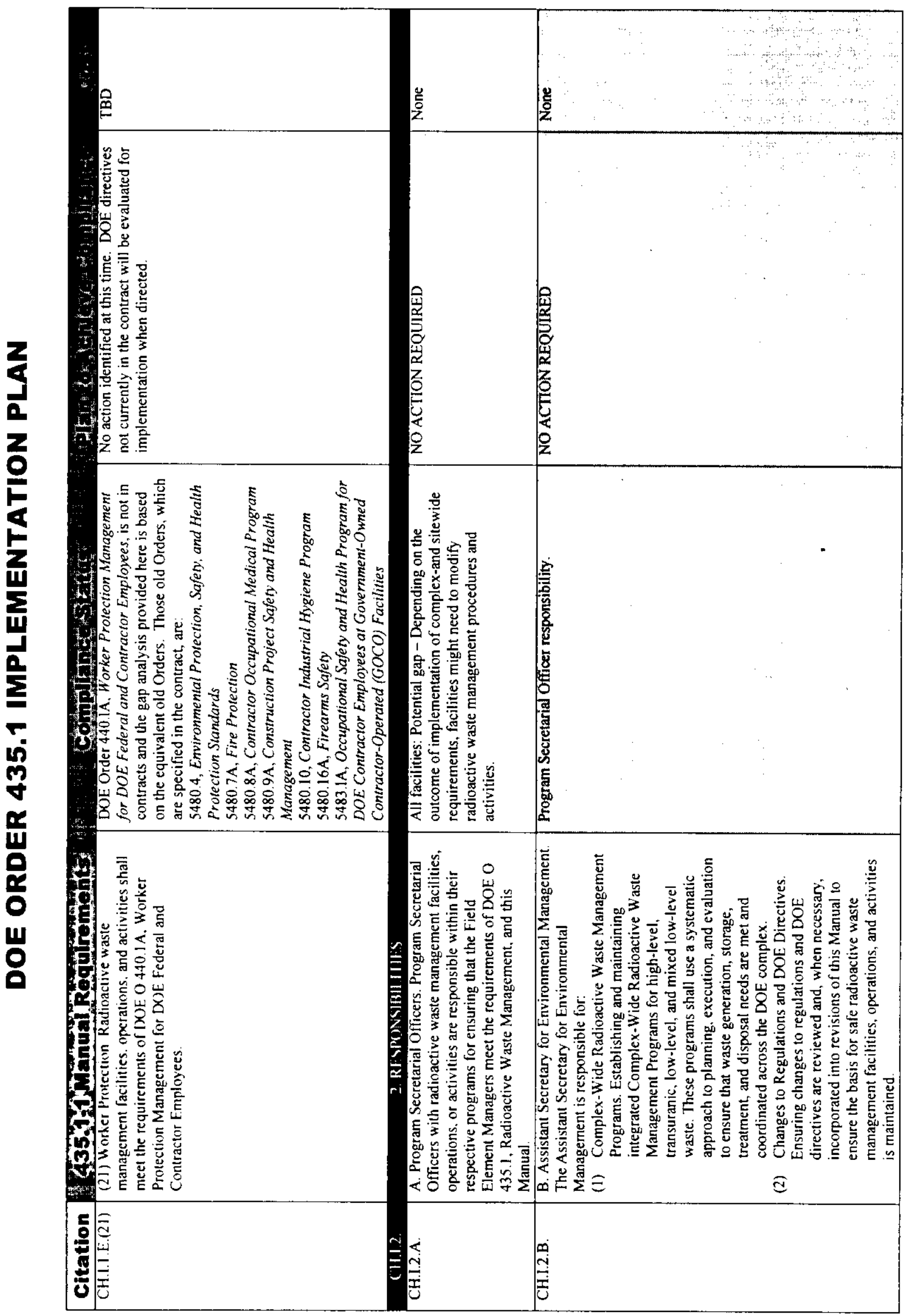




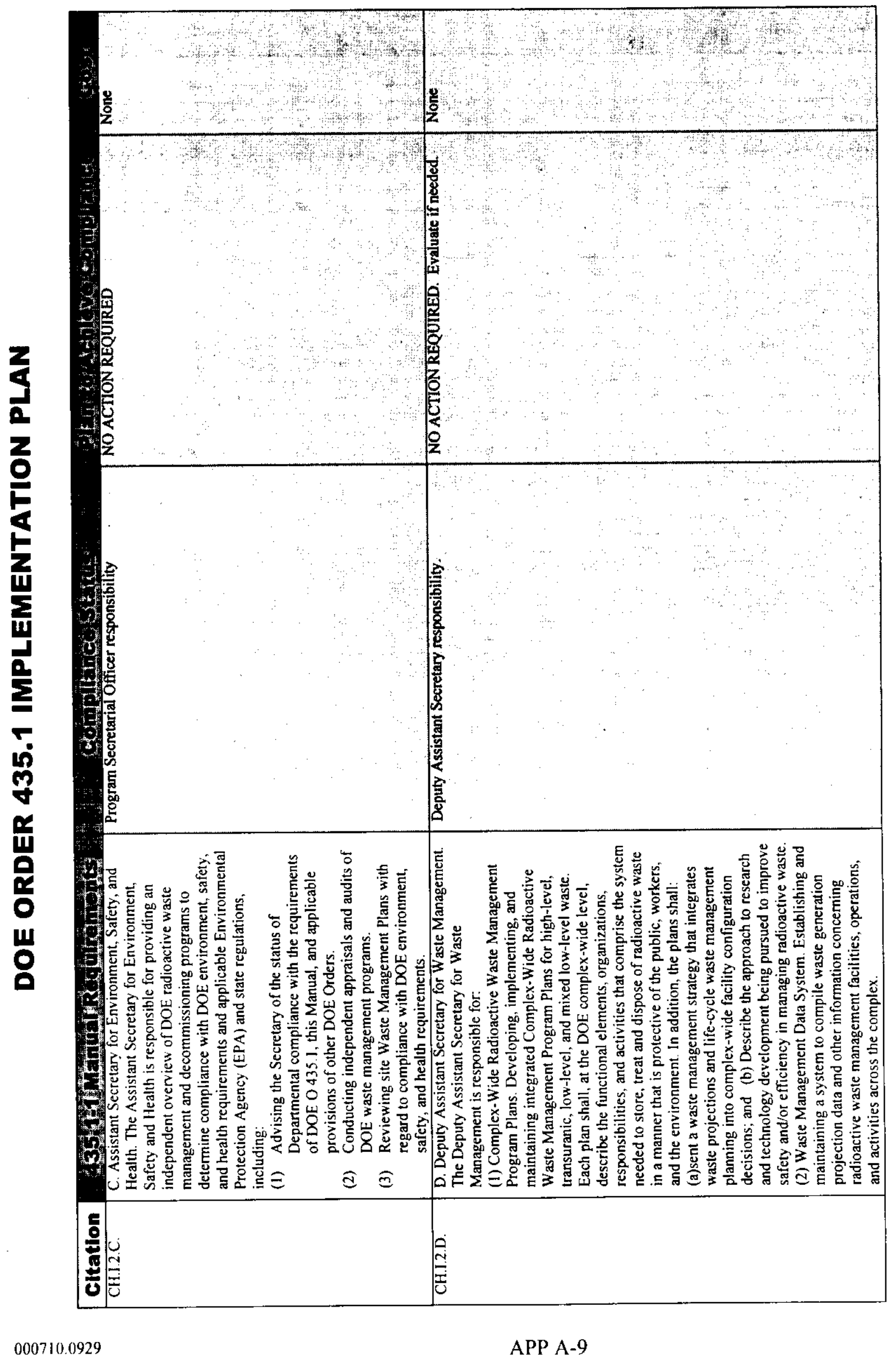




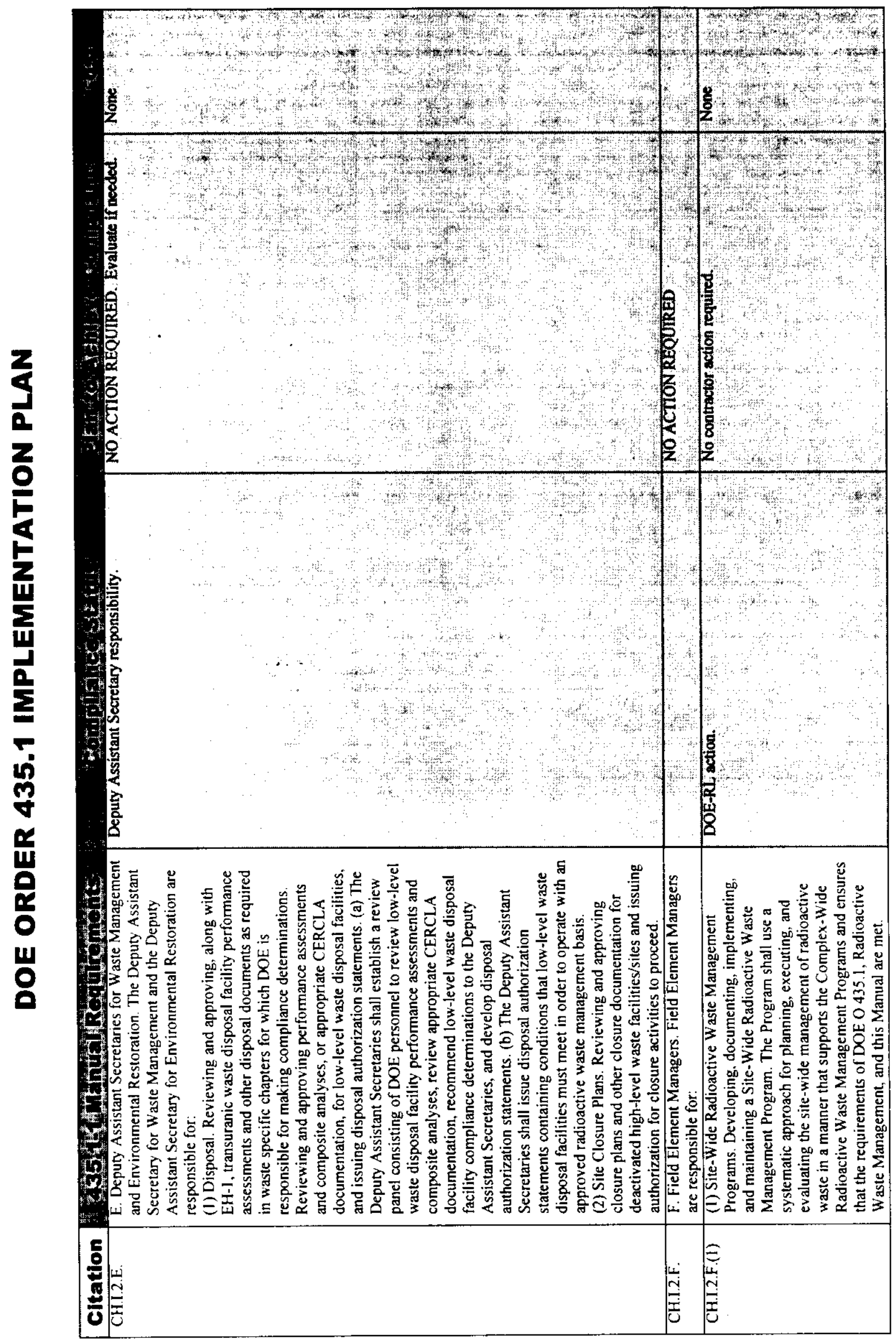


DOE/RL-2000-25, Rev. I

$06 / 2000$

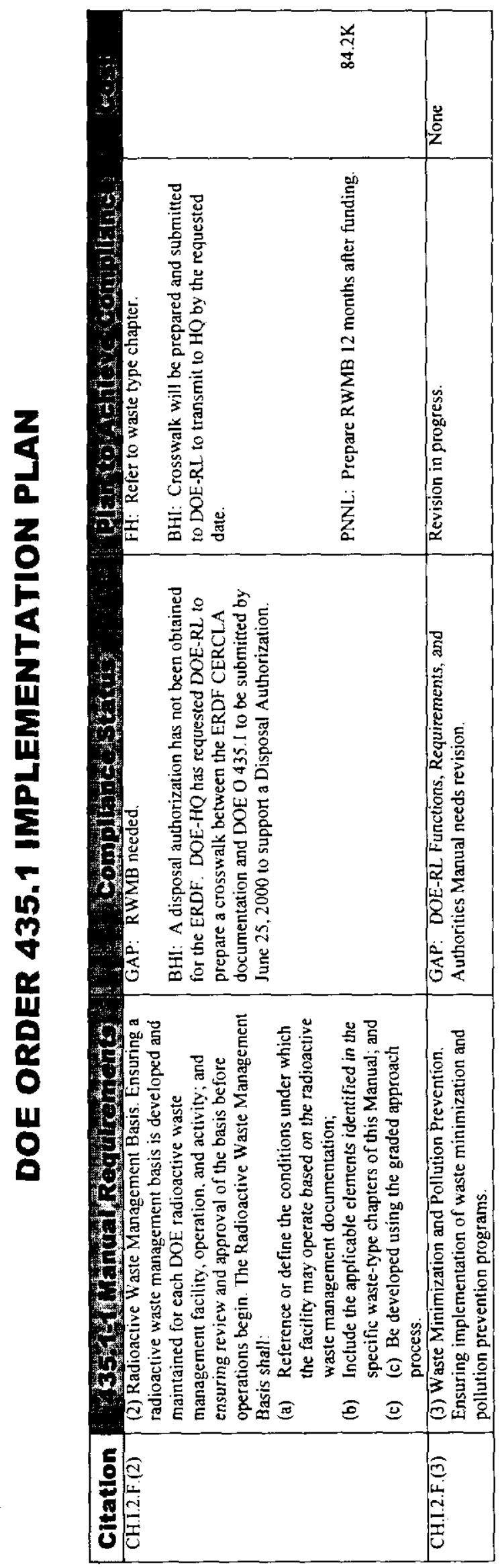


DOE/RL-2000-25, Rev. 1

$06 / 2000$

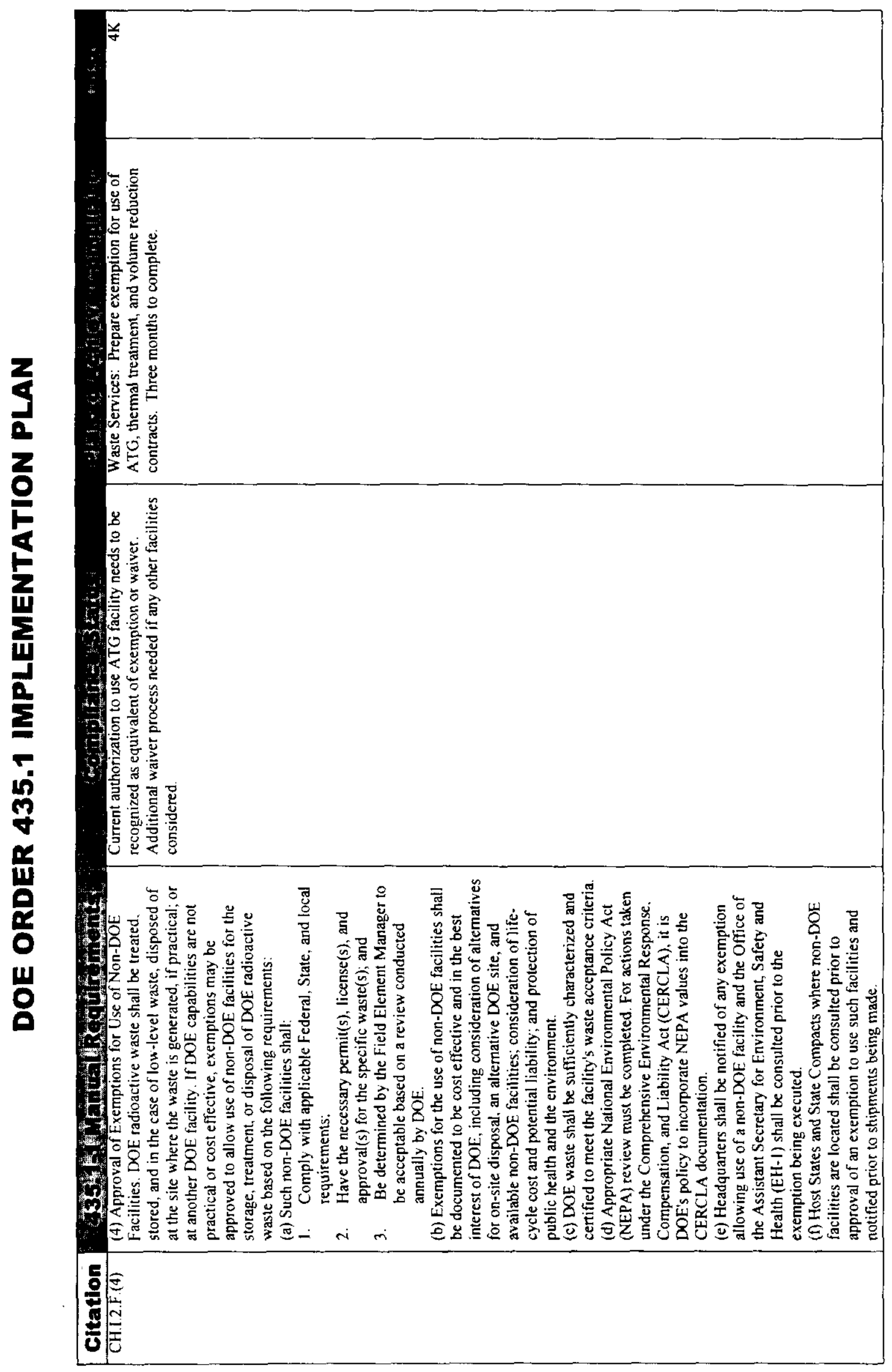




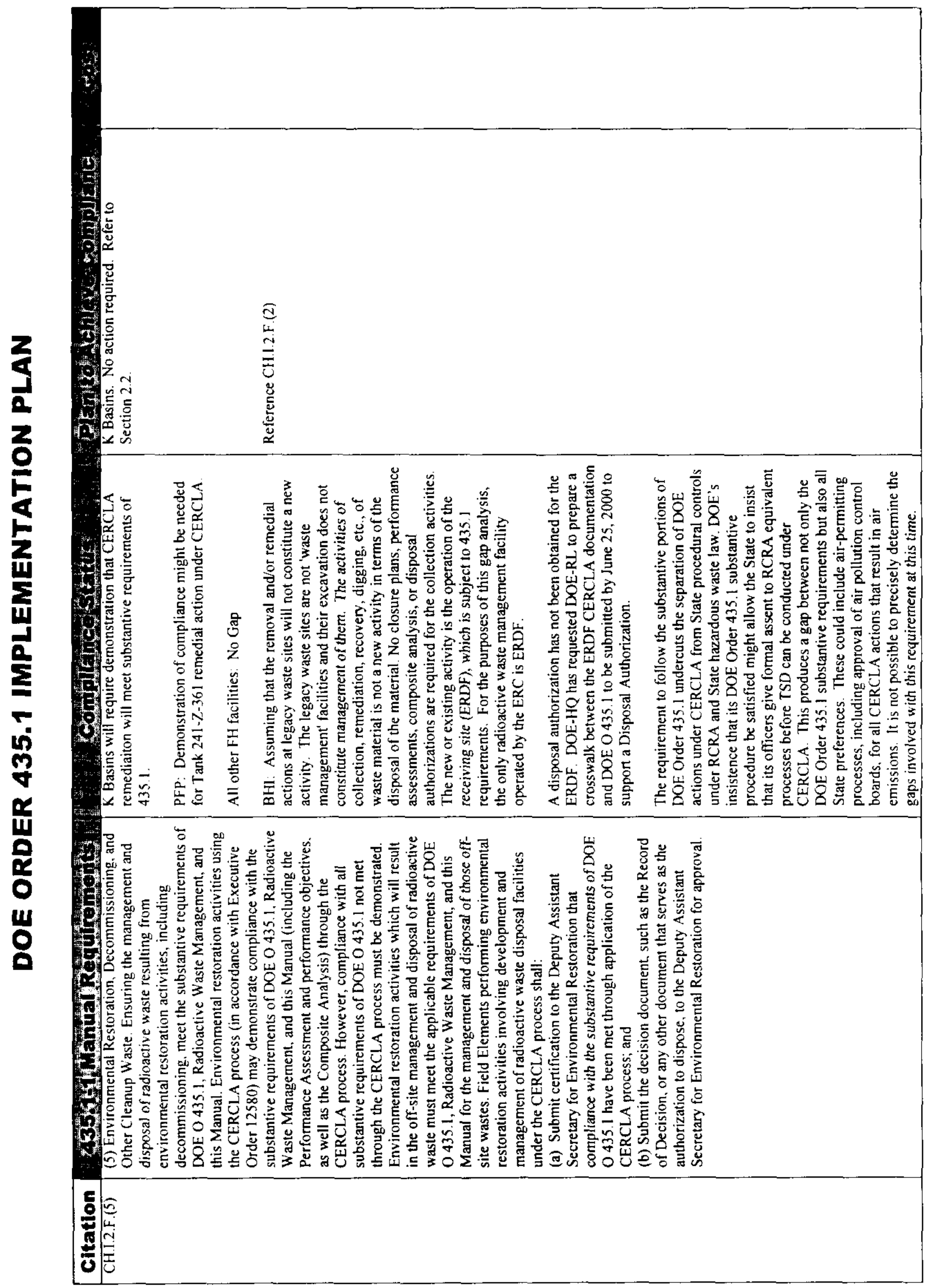


DOE/RL-2000-25, Rev. 1

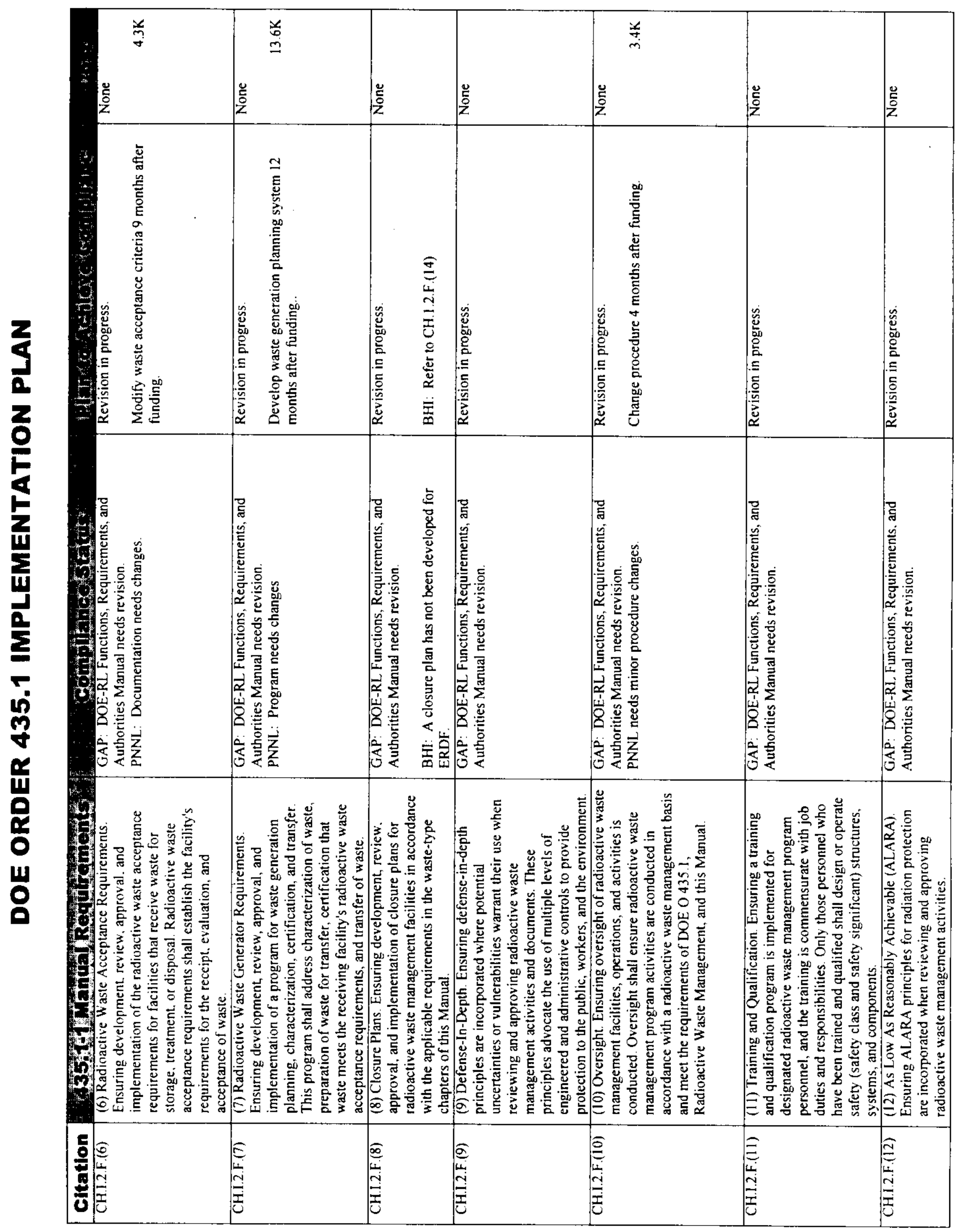




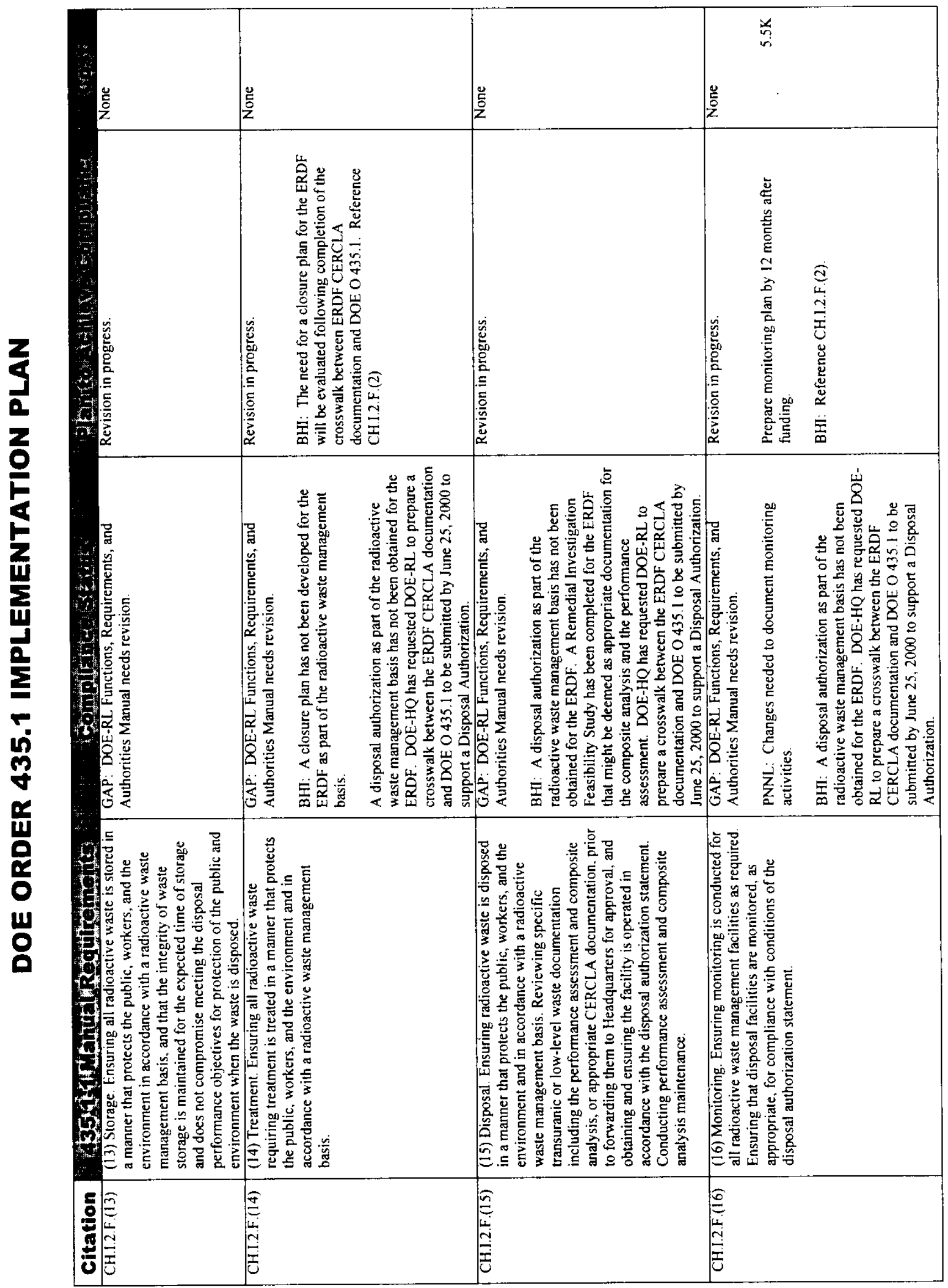


DOE/RL-2000-25, Rev. 1

$06 / 2000$

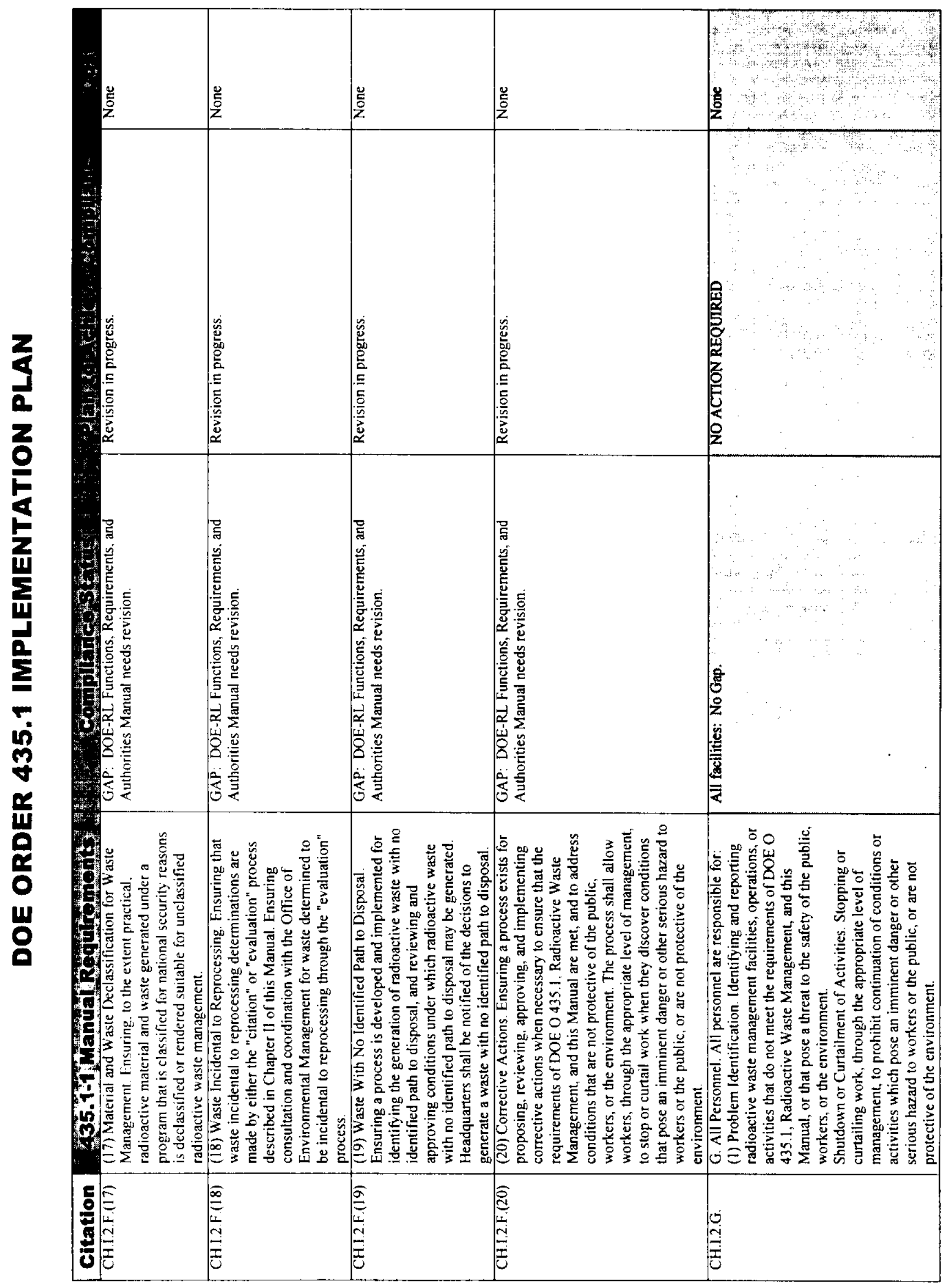


DOE/RL-2000-25, Rev. 1

$06 / 2000$

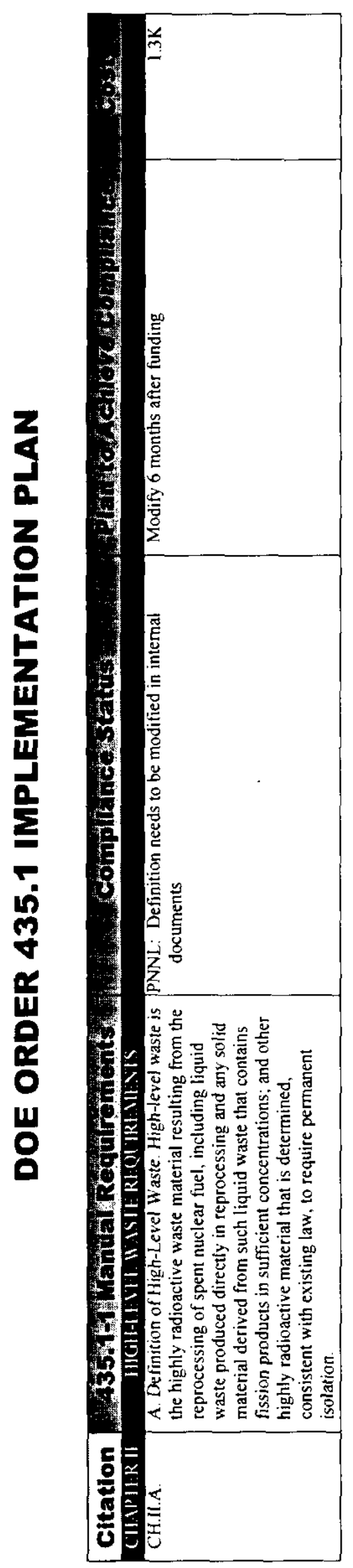




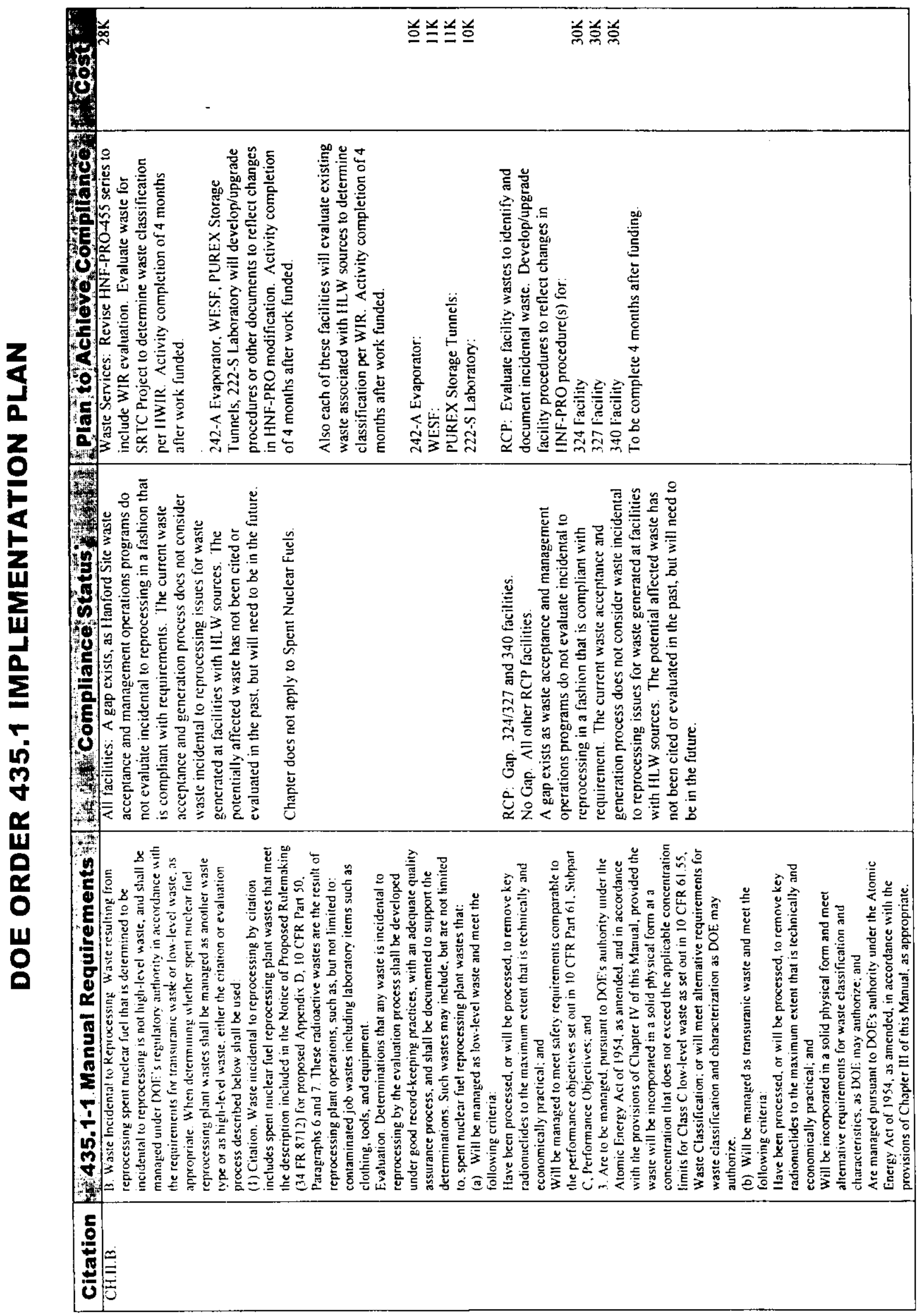




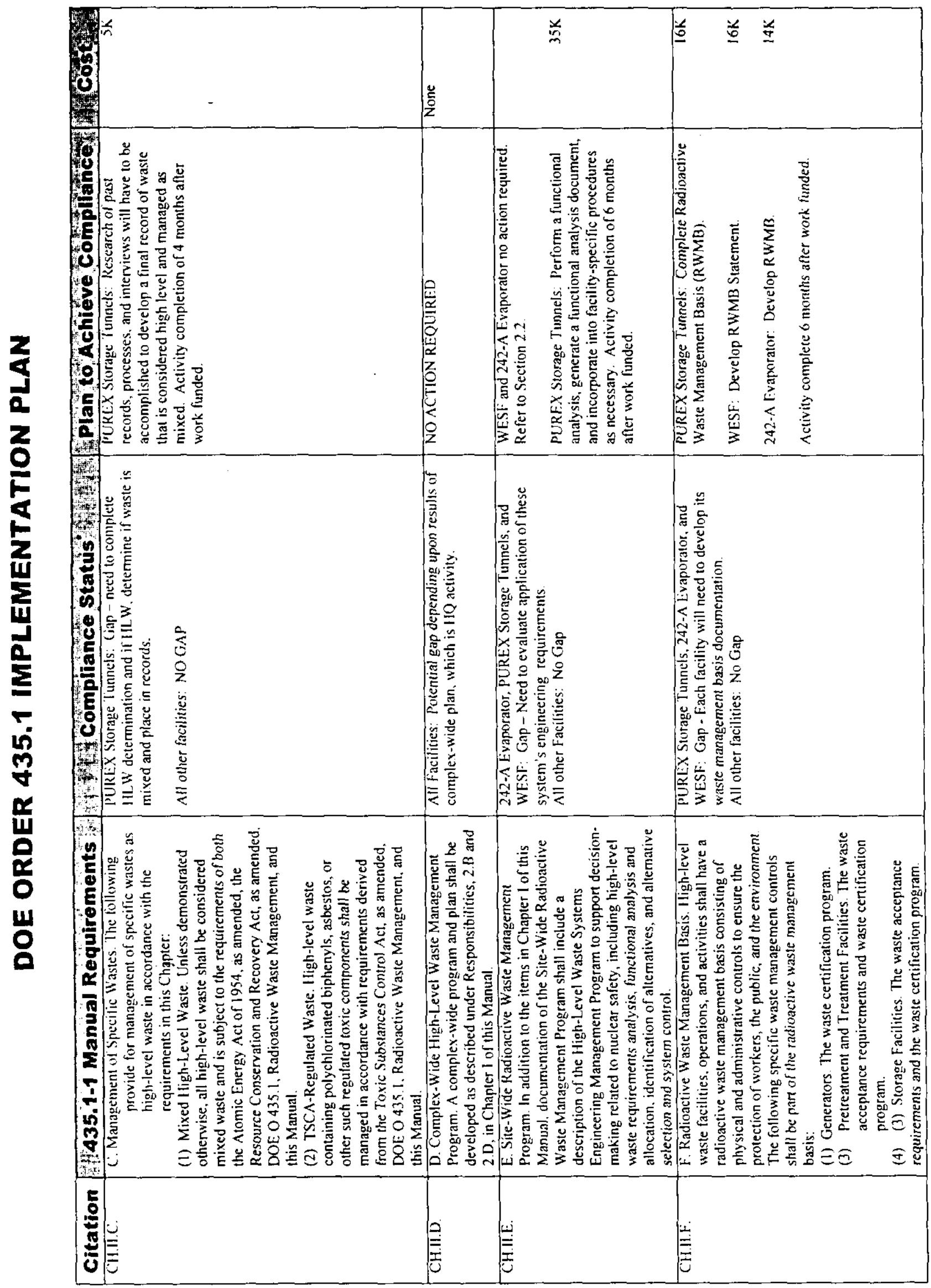


DOE/RL-2000-25, Rev. 1

$06 / 2000$

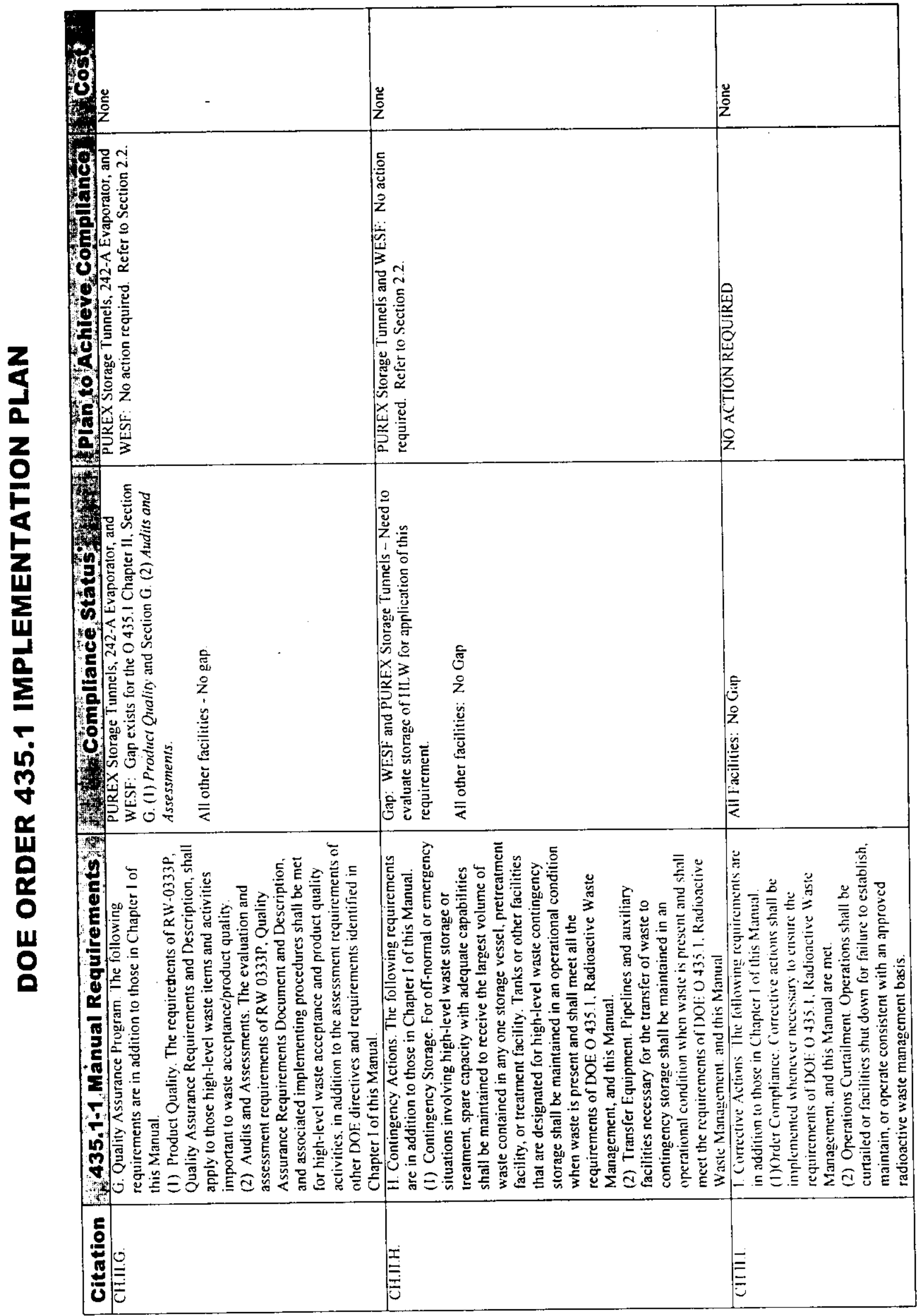


DOE/RL-2000-25, Rev. I $06 / 2000$

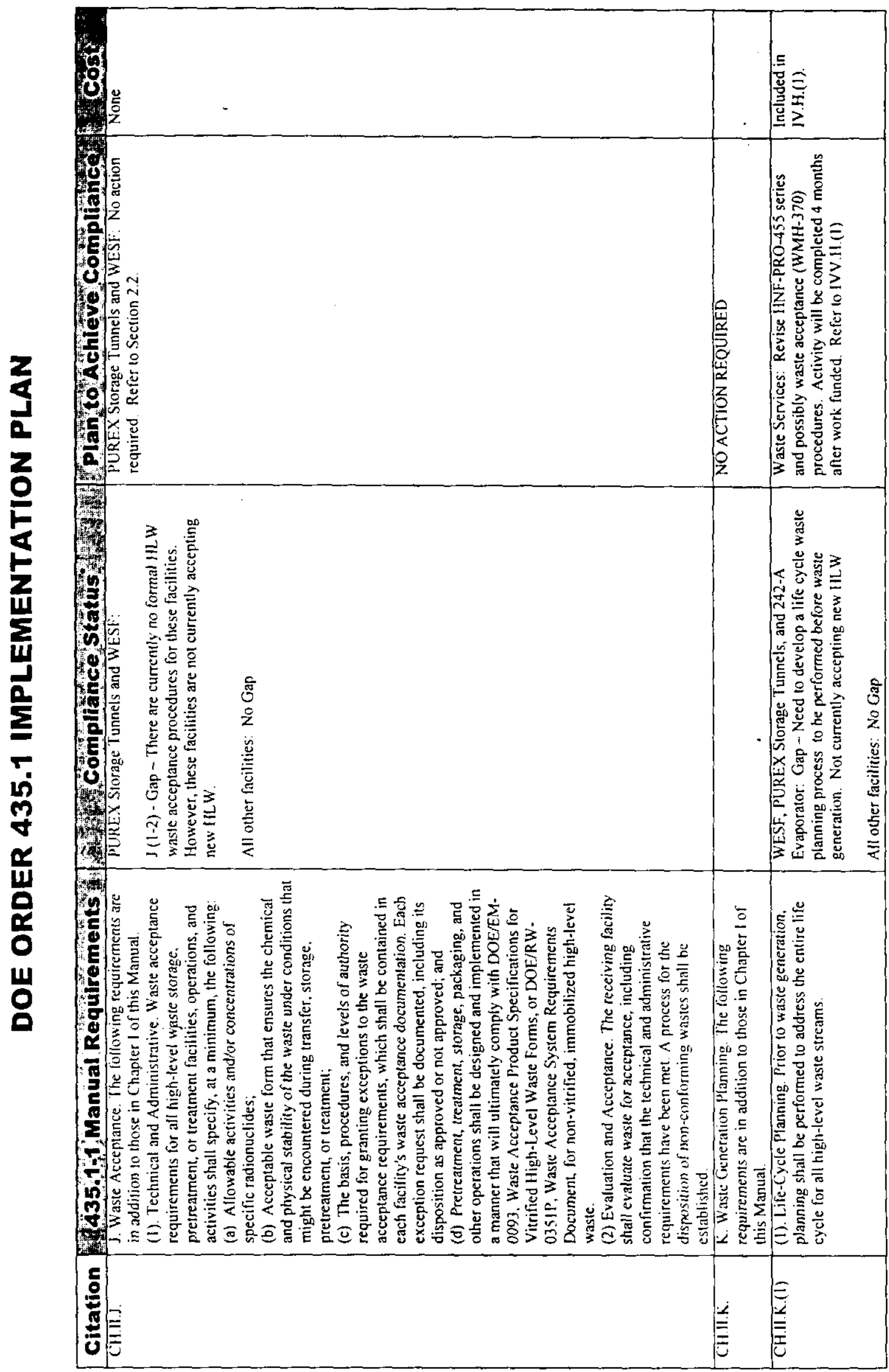


DOE/RL-2000-25, Rev. 1

$06 / 2000$

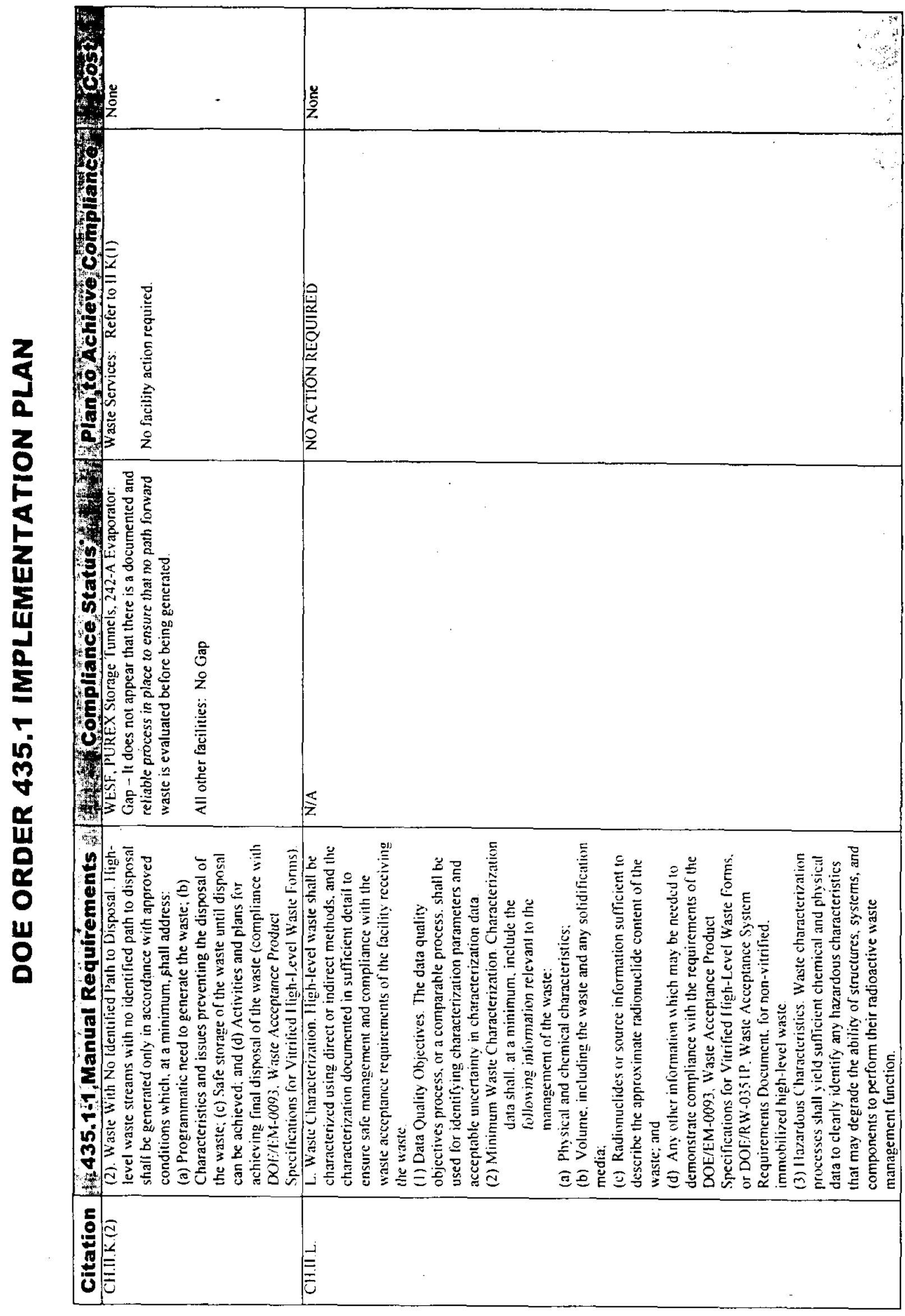




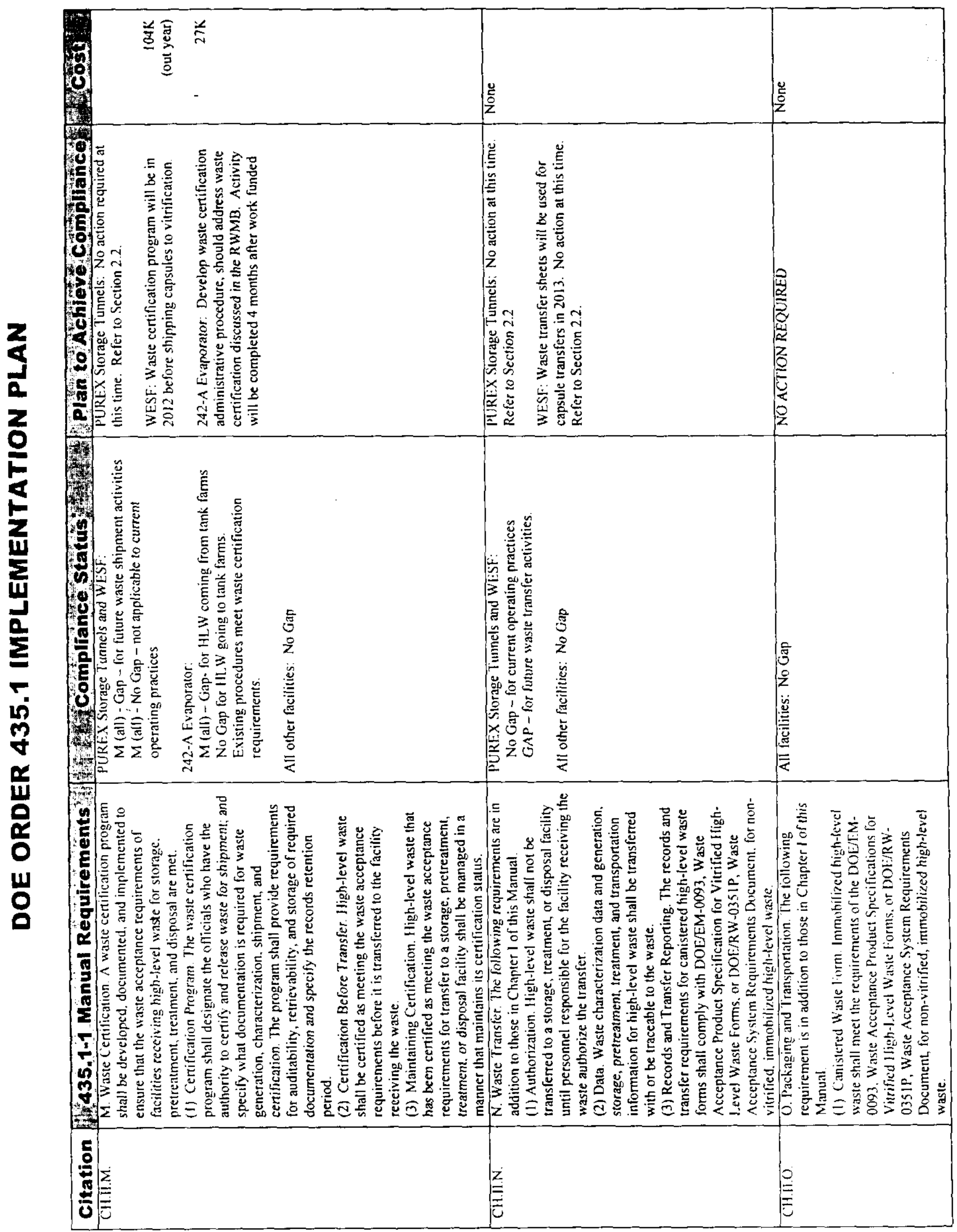


DOE/RL-2000-25, Rev. I

$06 / 2000$

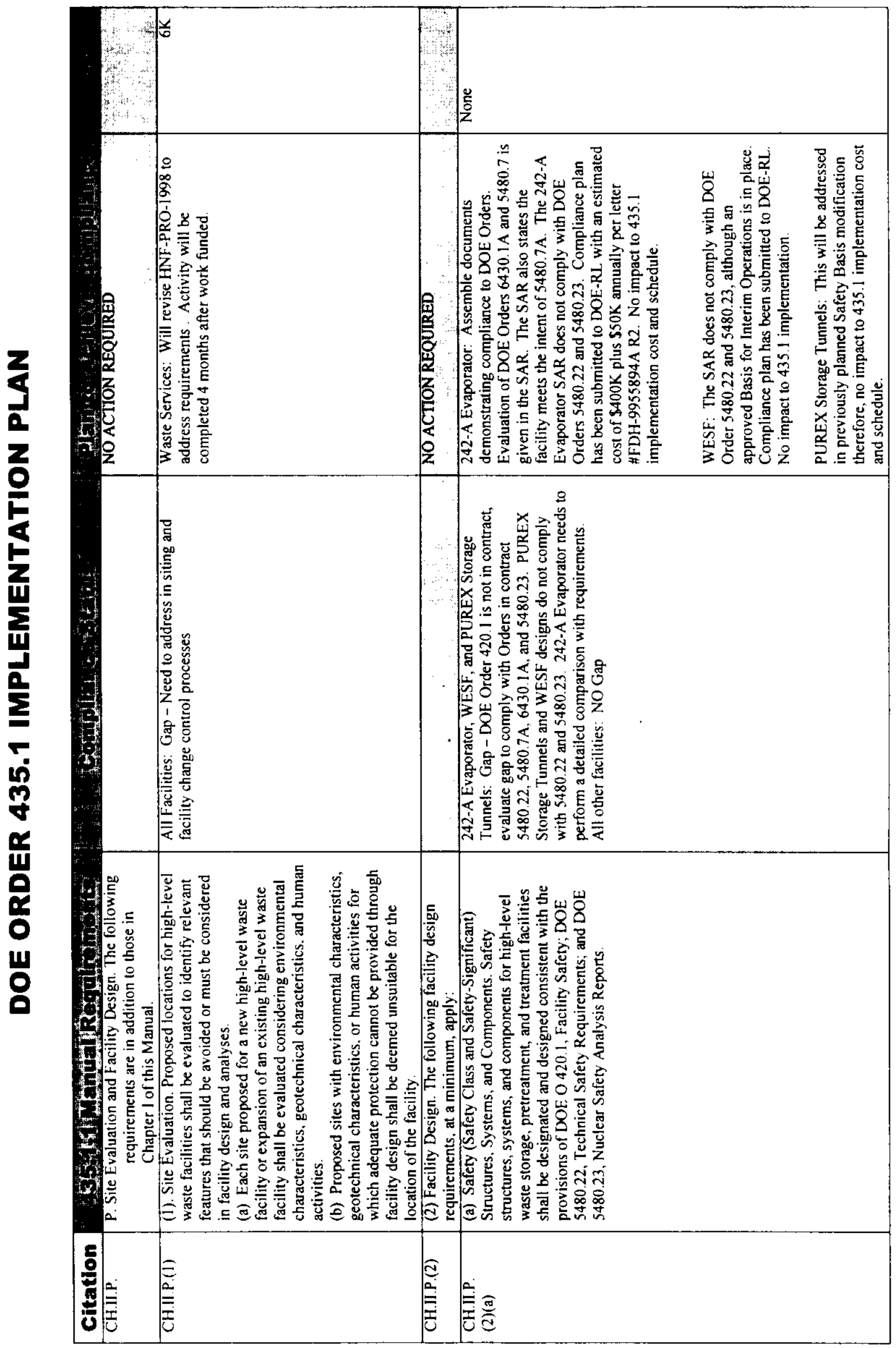


DOE/RL-2000-25, Rev. I $06 / 2000$

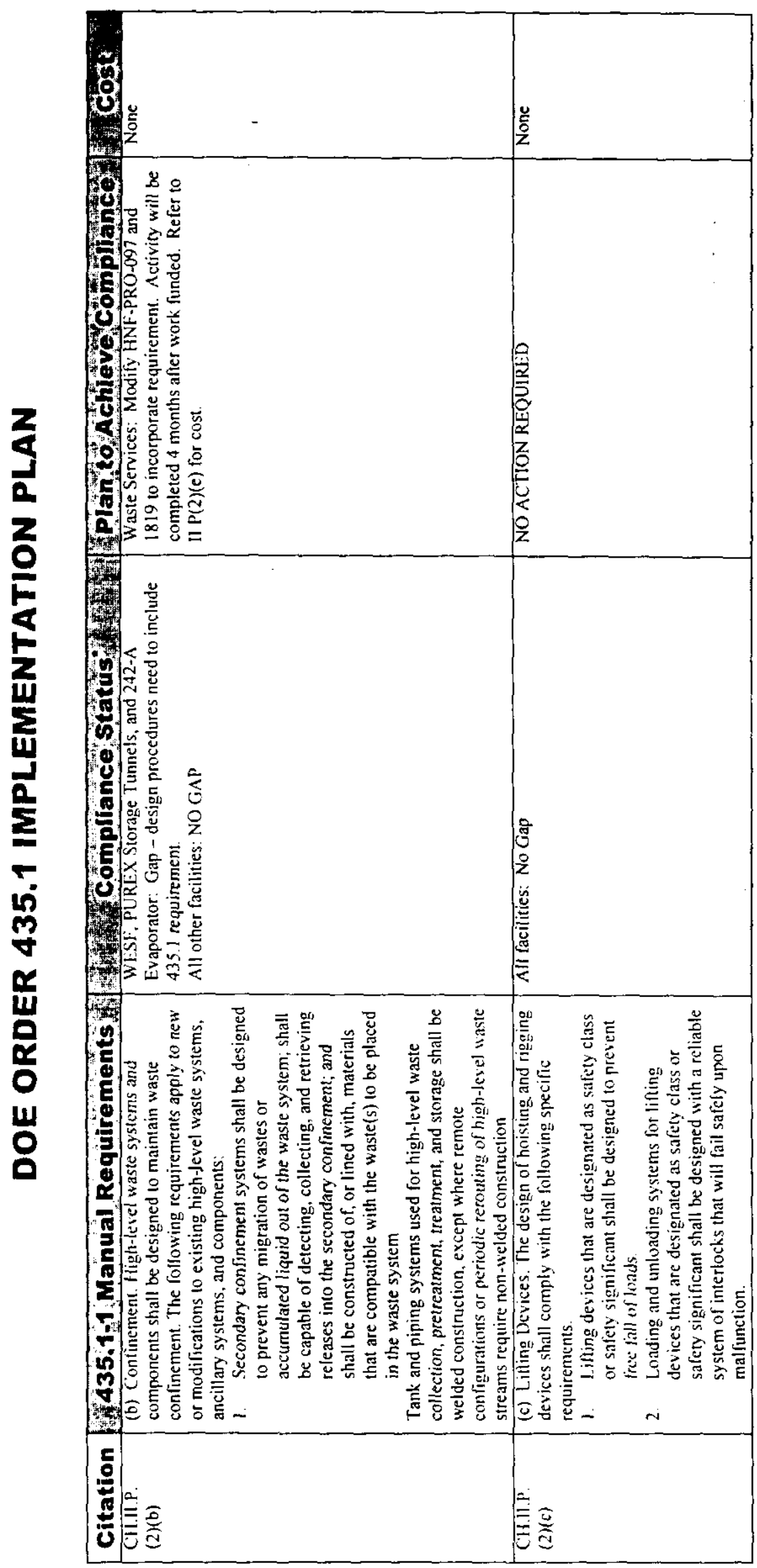




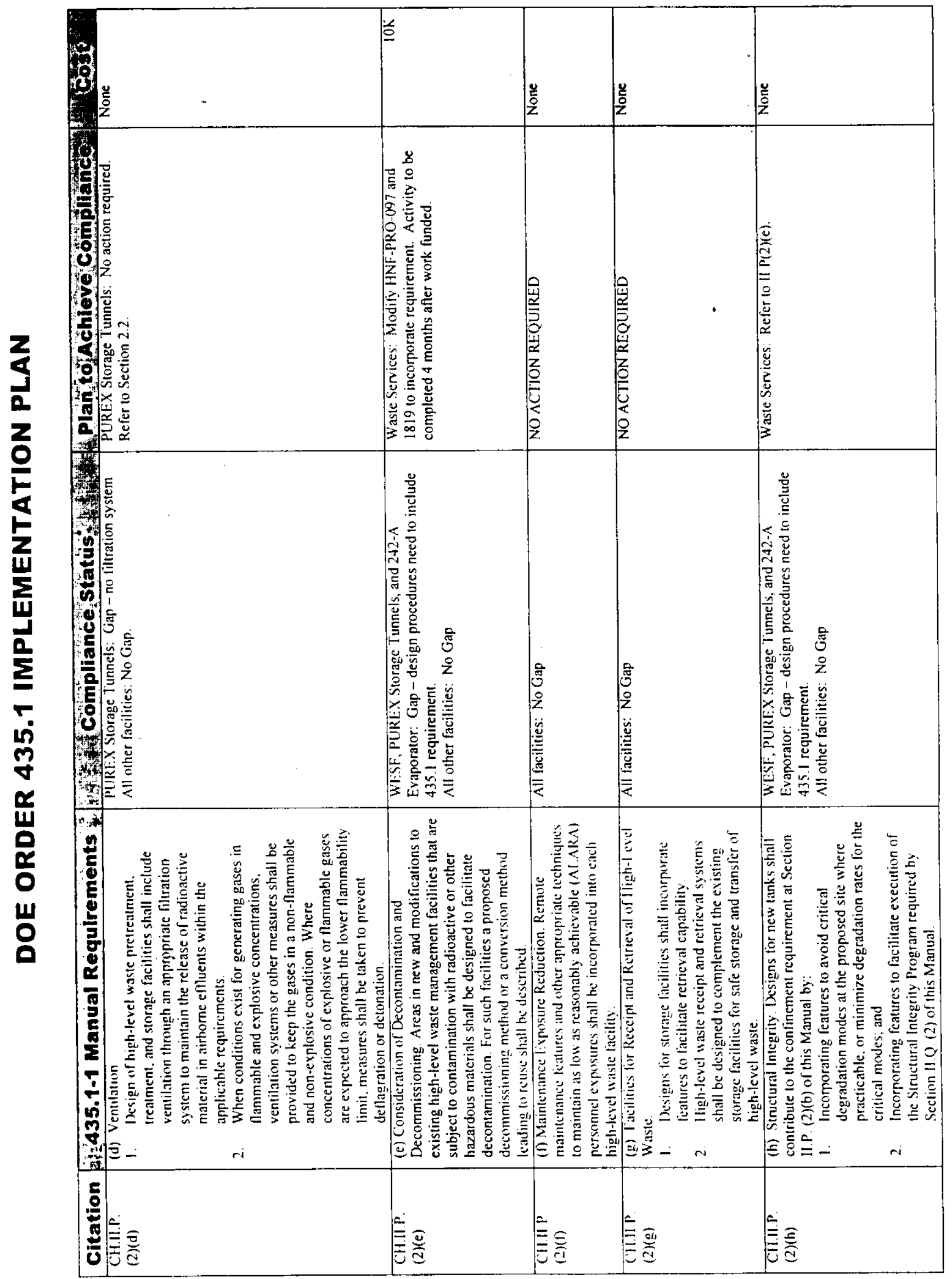


DOE/RL-2000-25, Rev. 1

$06 / 2000$

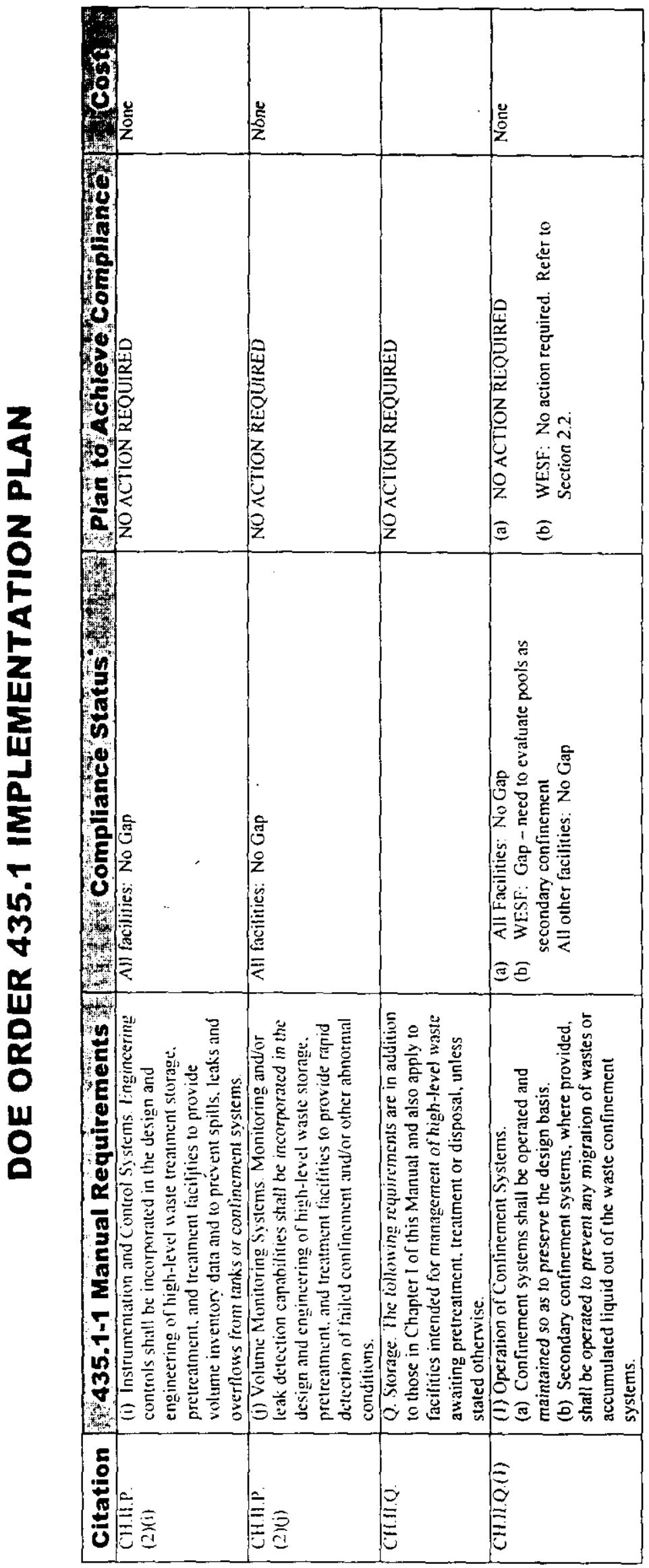




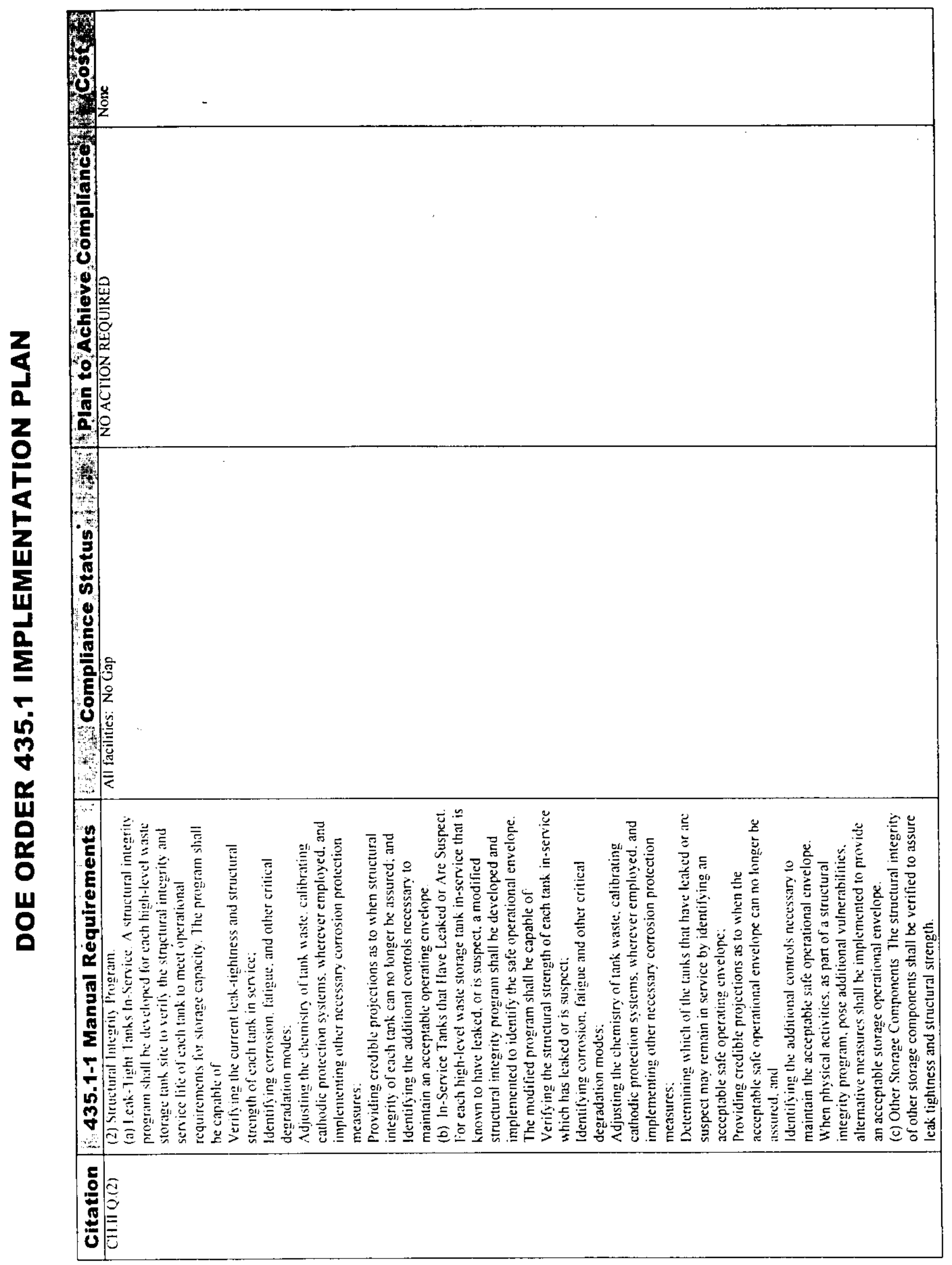




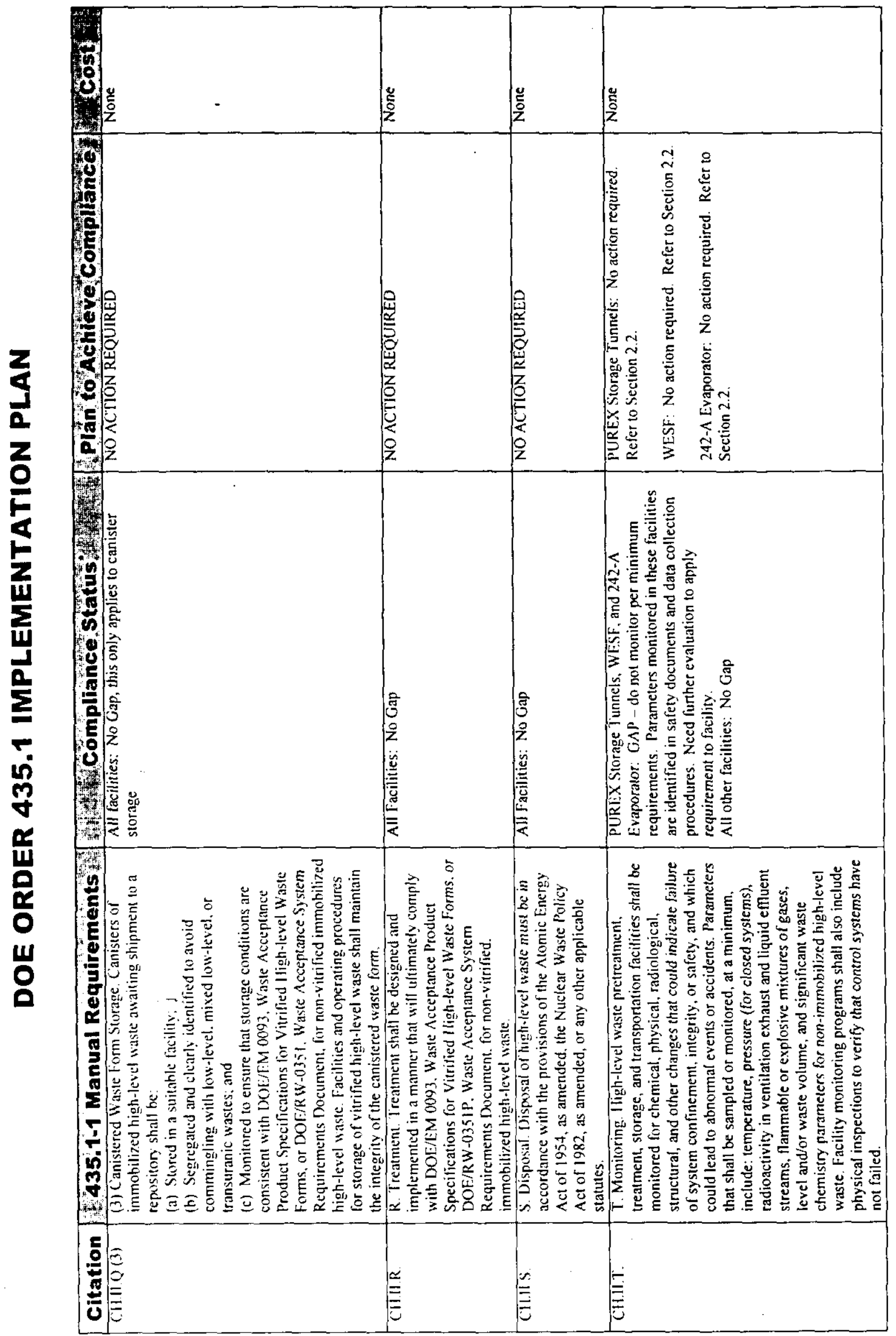


DOE/RL-2000-25, Rev. I

$06 / 2000$

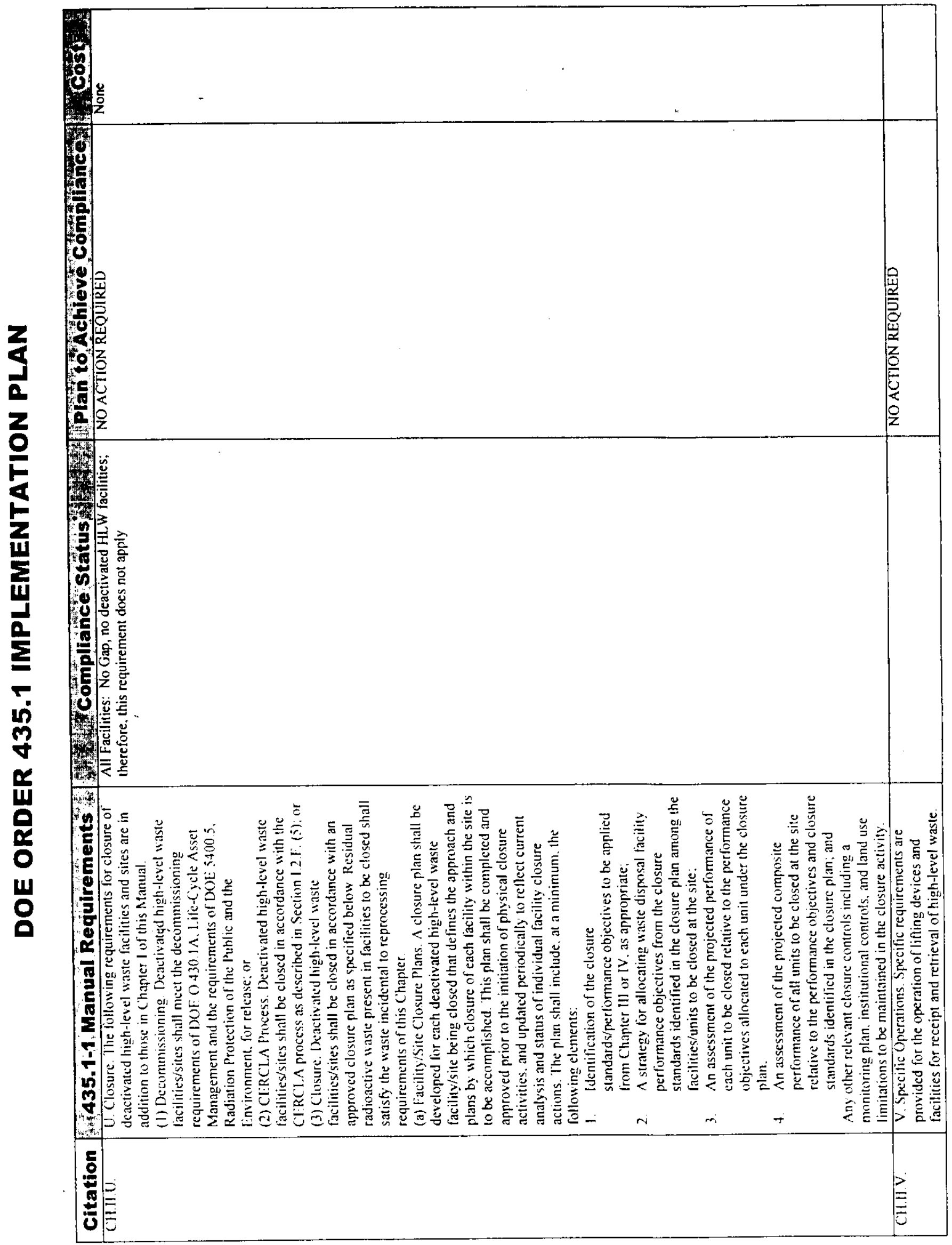




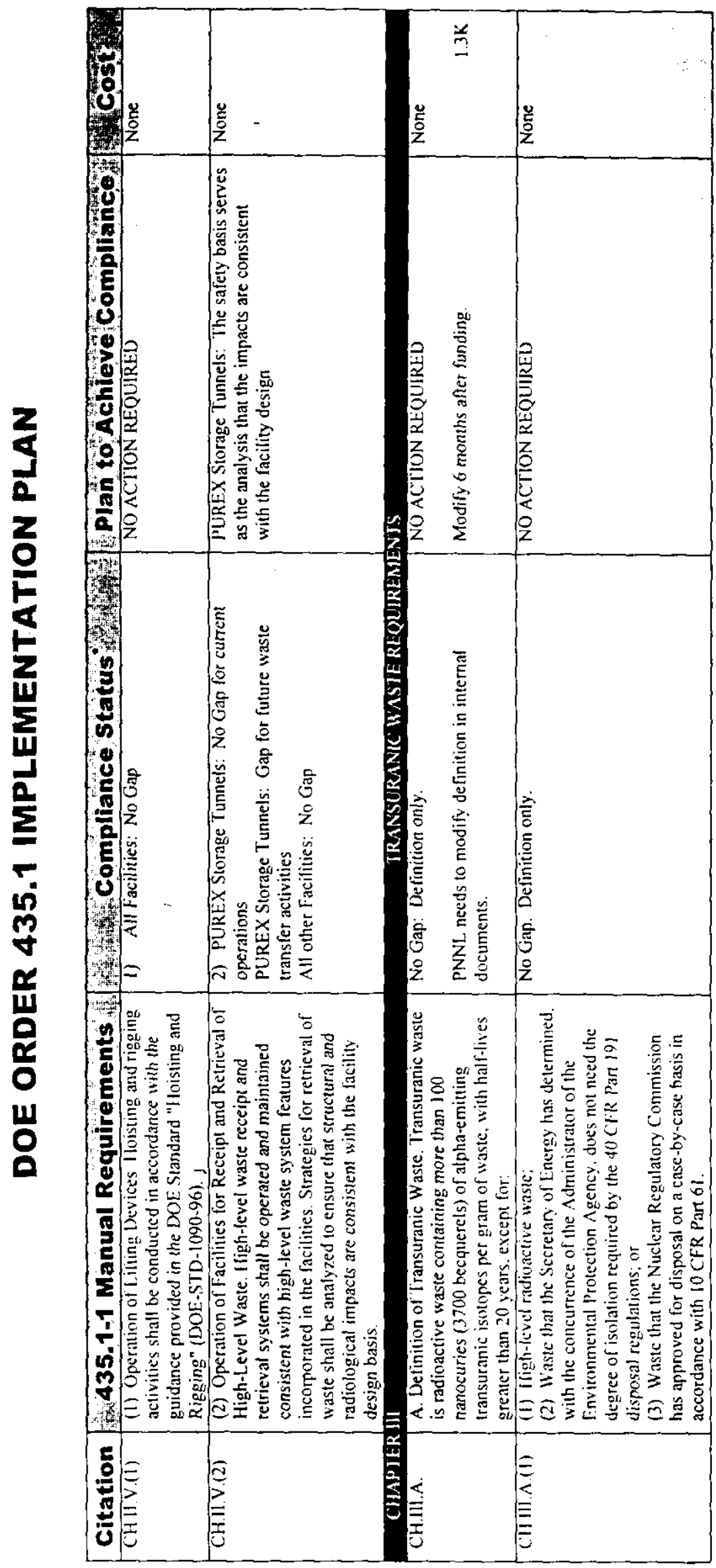


DOE/RL-2000-25, Rev. I

$06 / 2000$

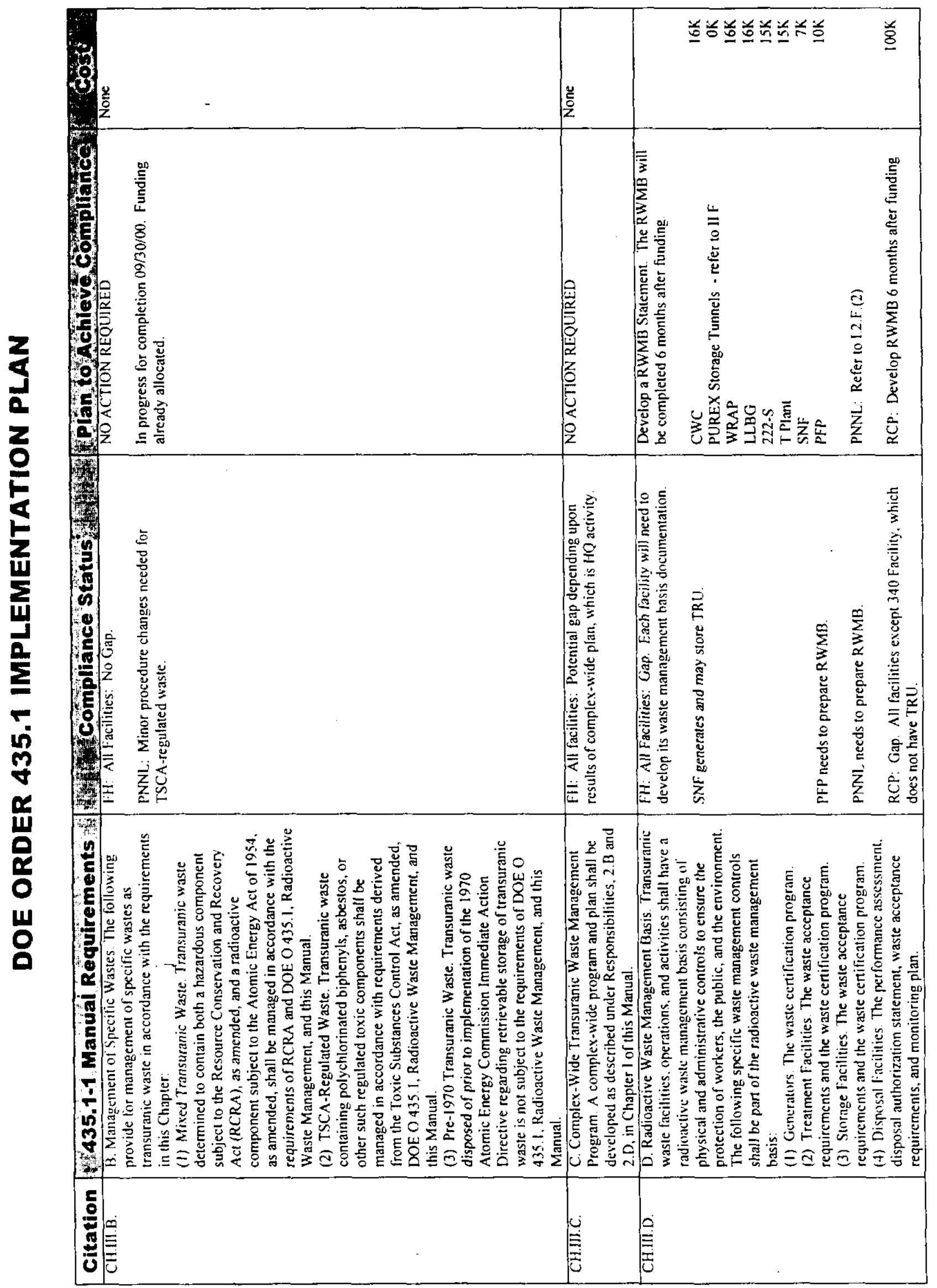




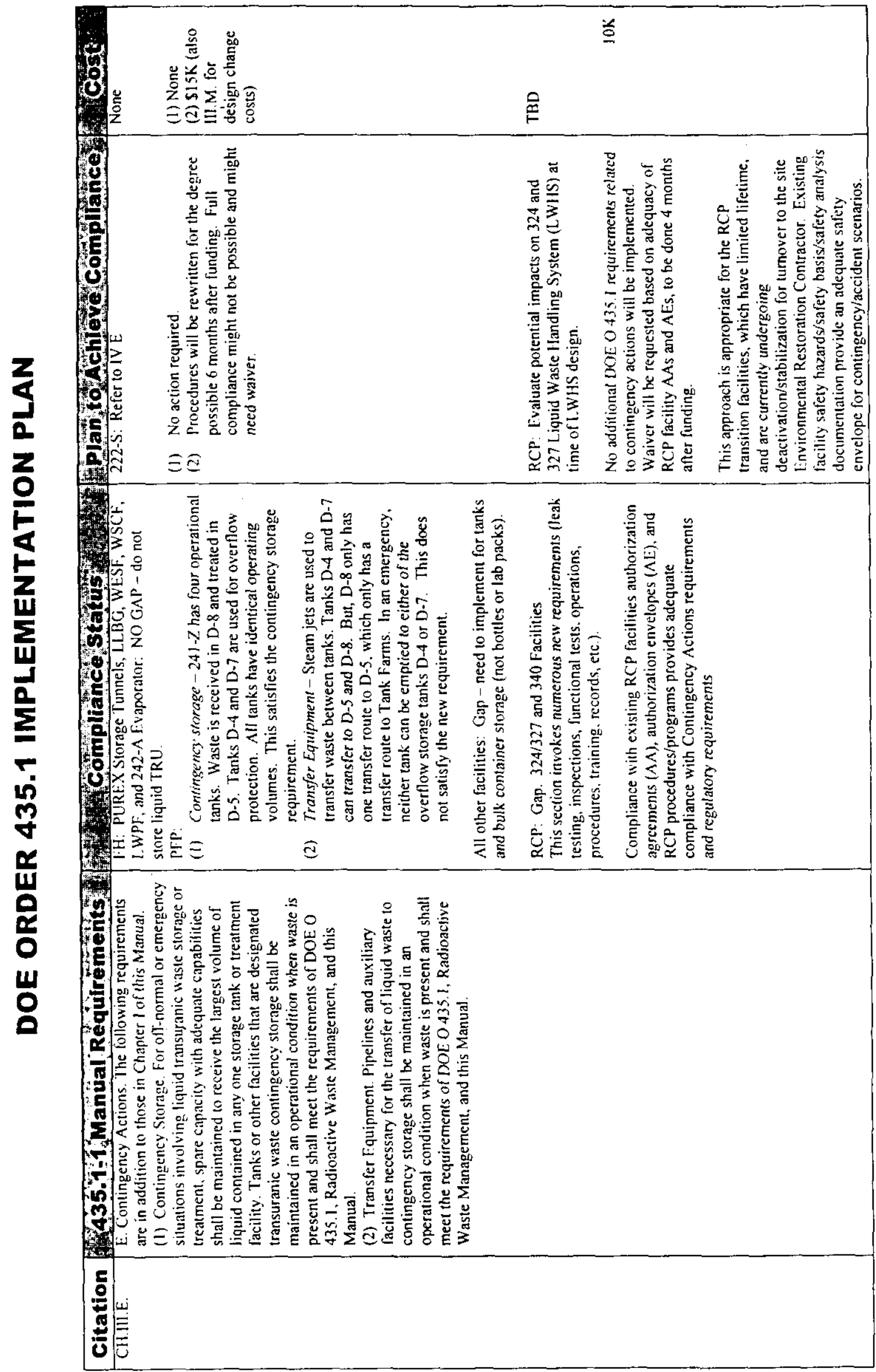


DOE/RL-2000-25, Rev. 1

$06 / 2000$

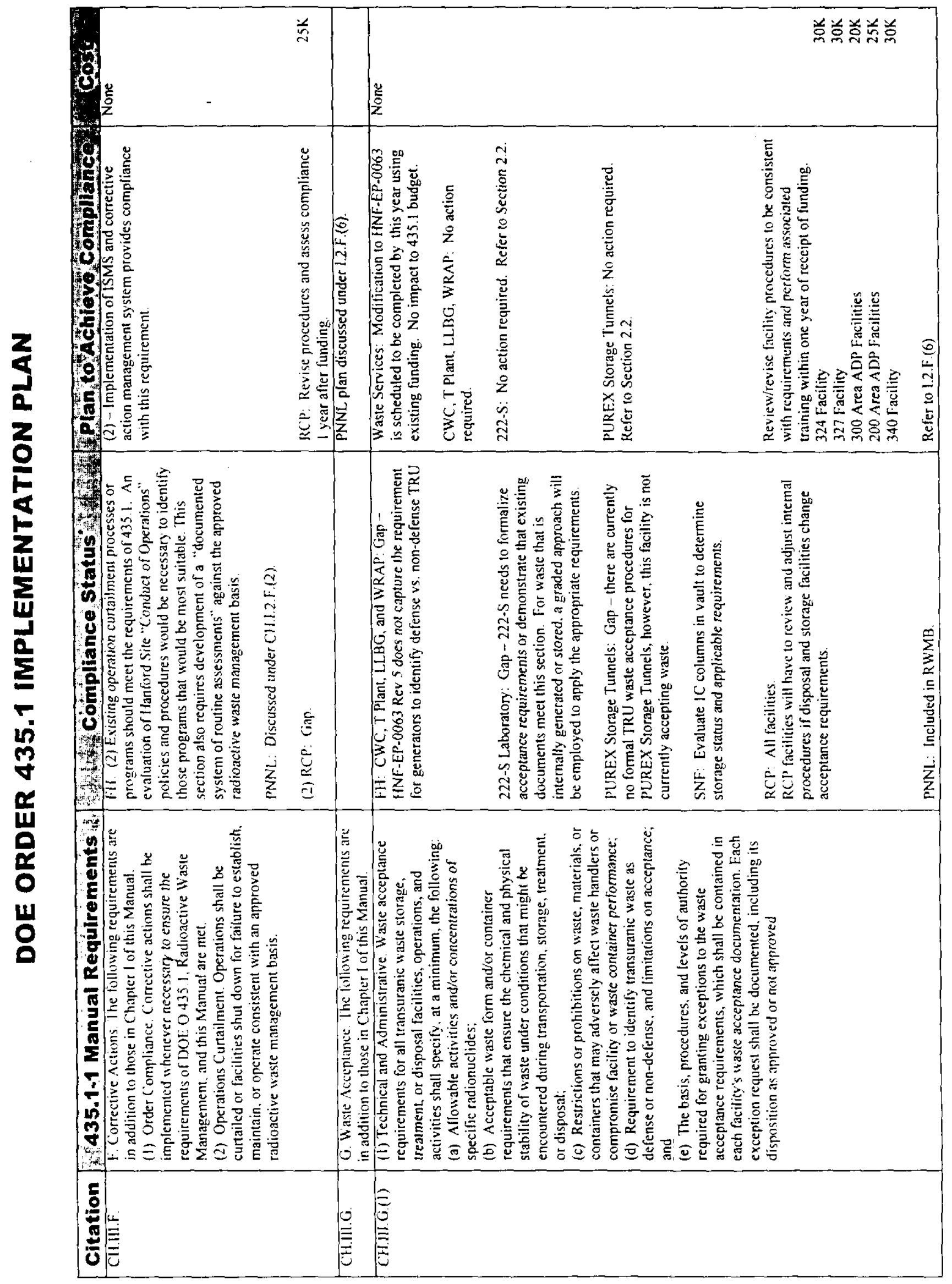


DOE/RL-2000-25, Rev. 1

06/2000

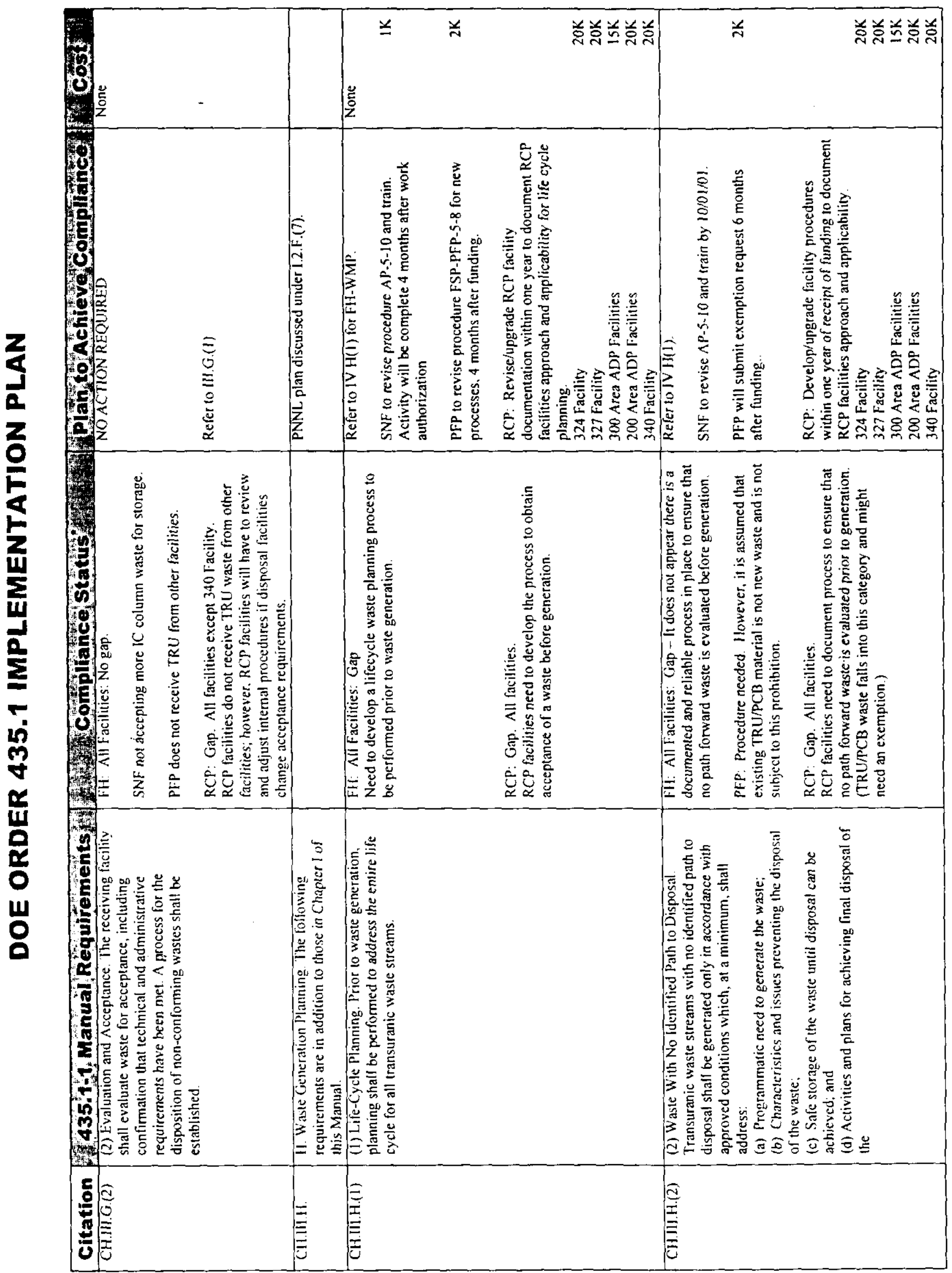




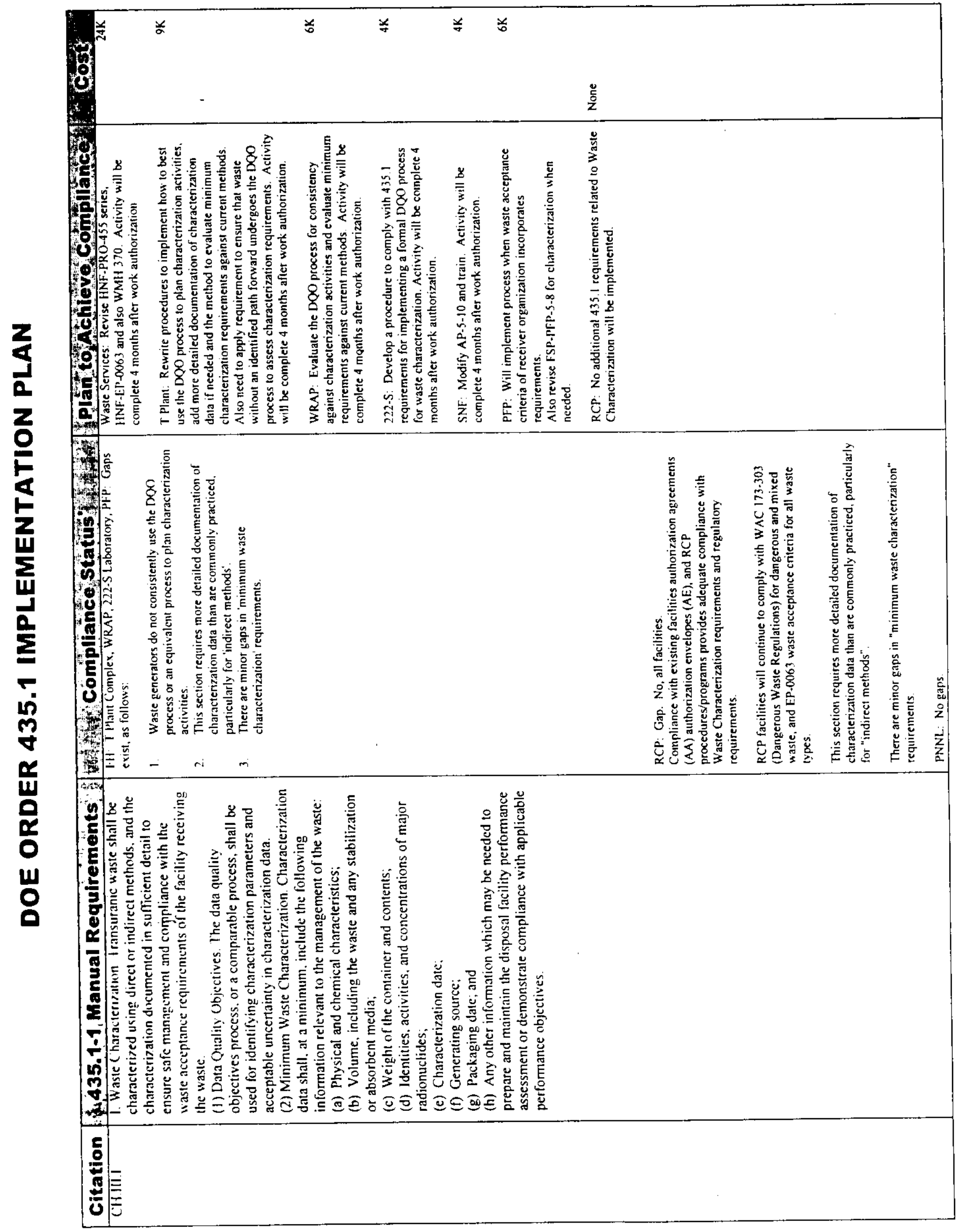




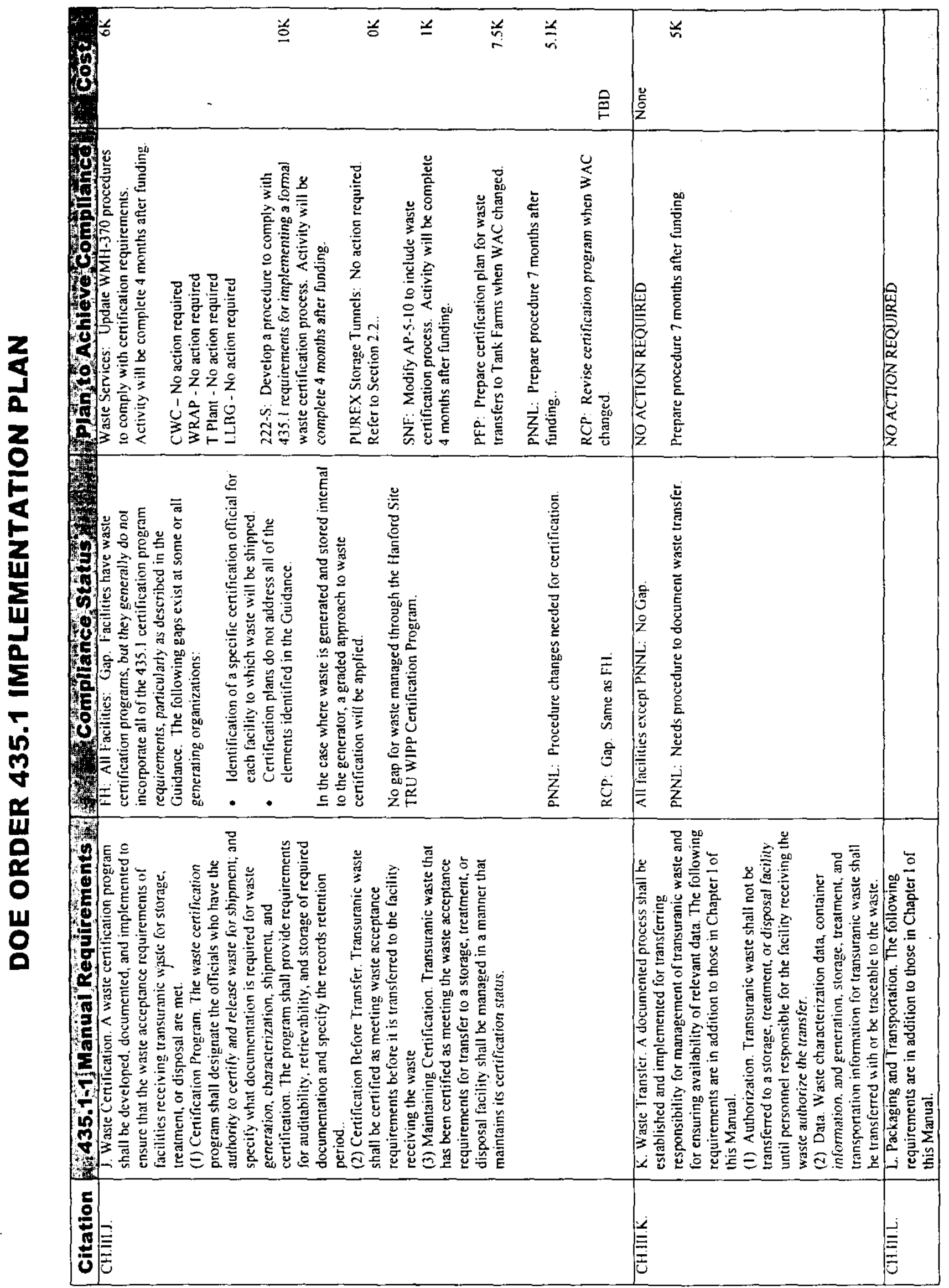


DOE/RL-2000-25, Rev. 1

$06 / 2000$

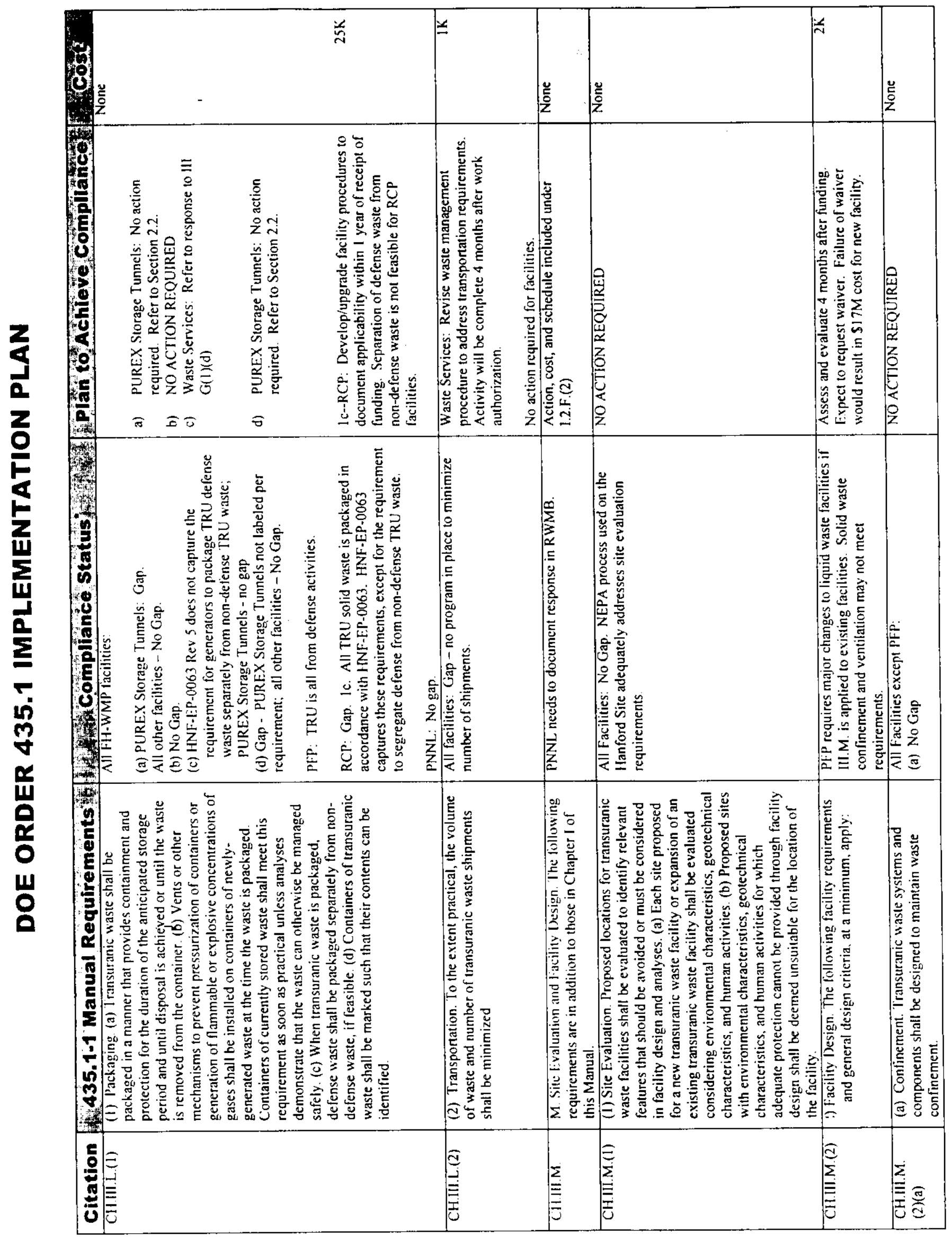




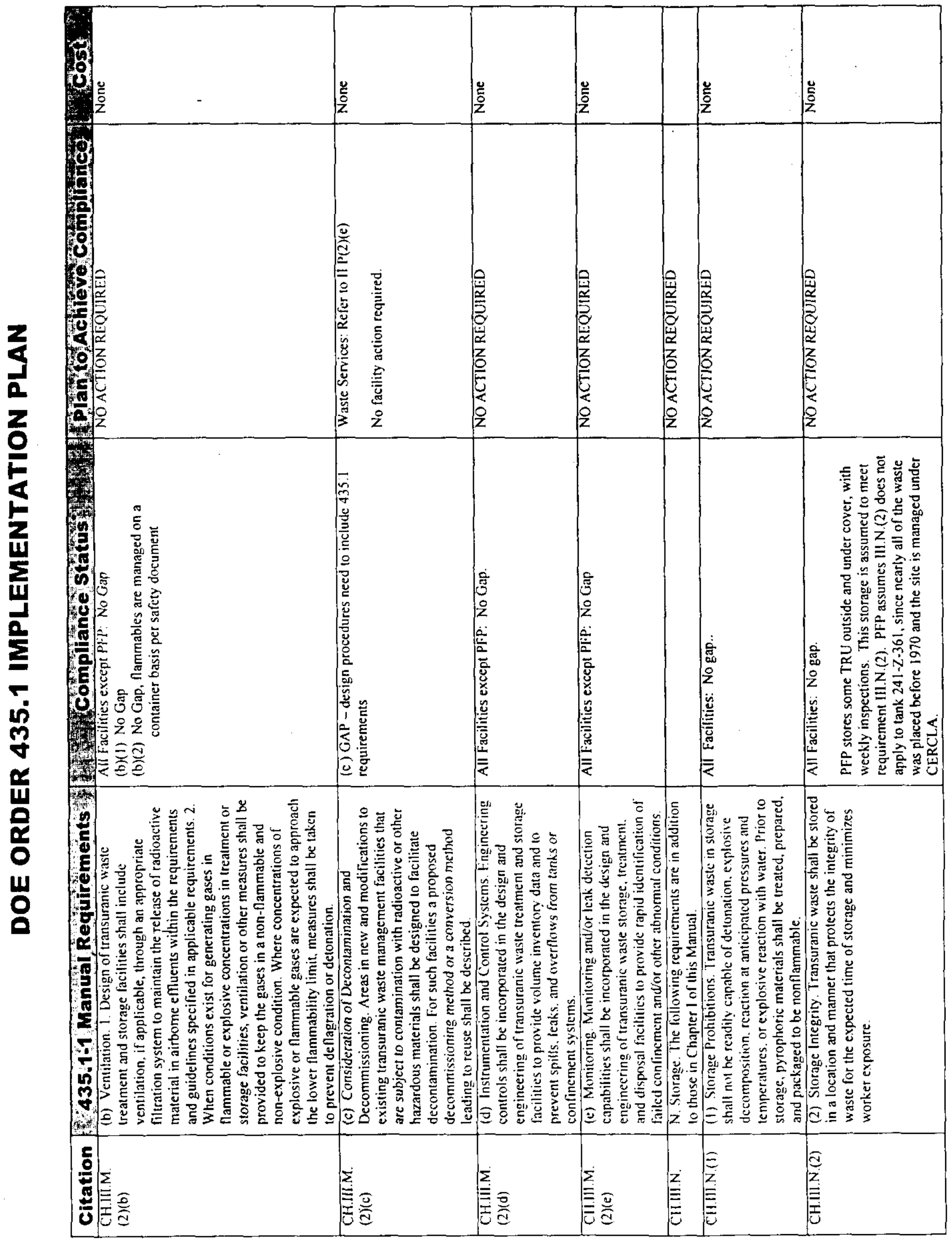


DOE/RL-2000-25, Rev. 1

$06 / 2000$

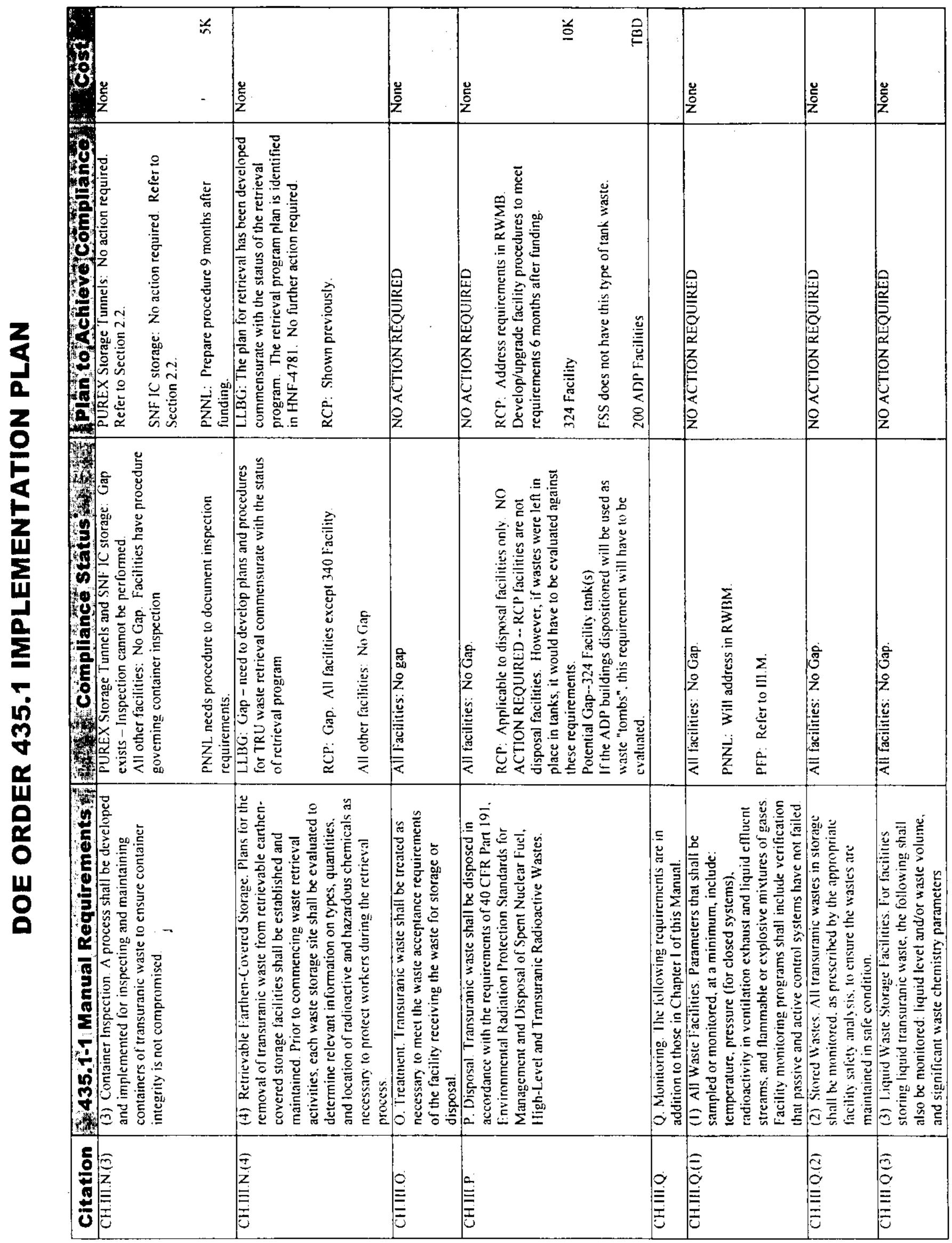




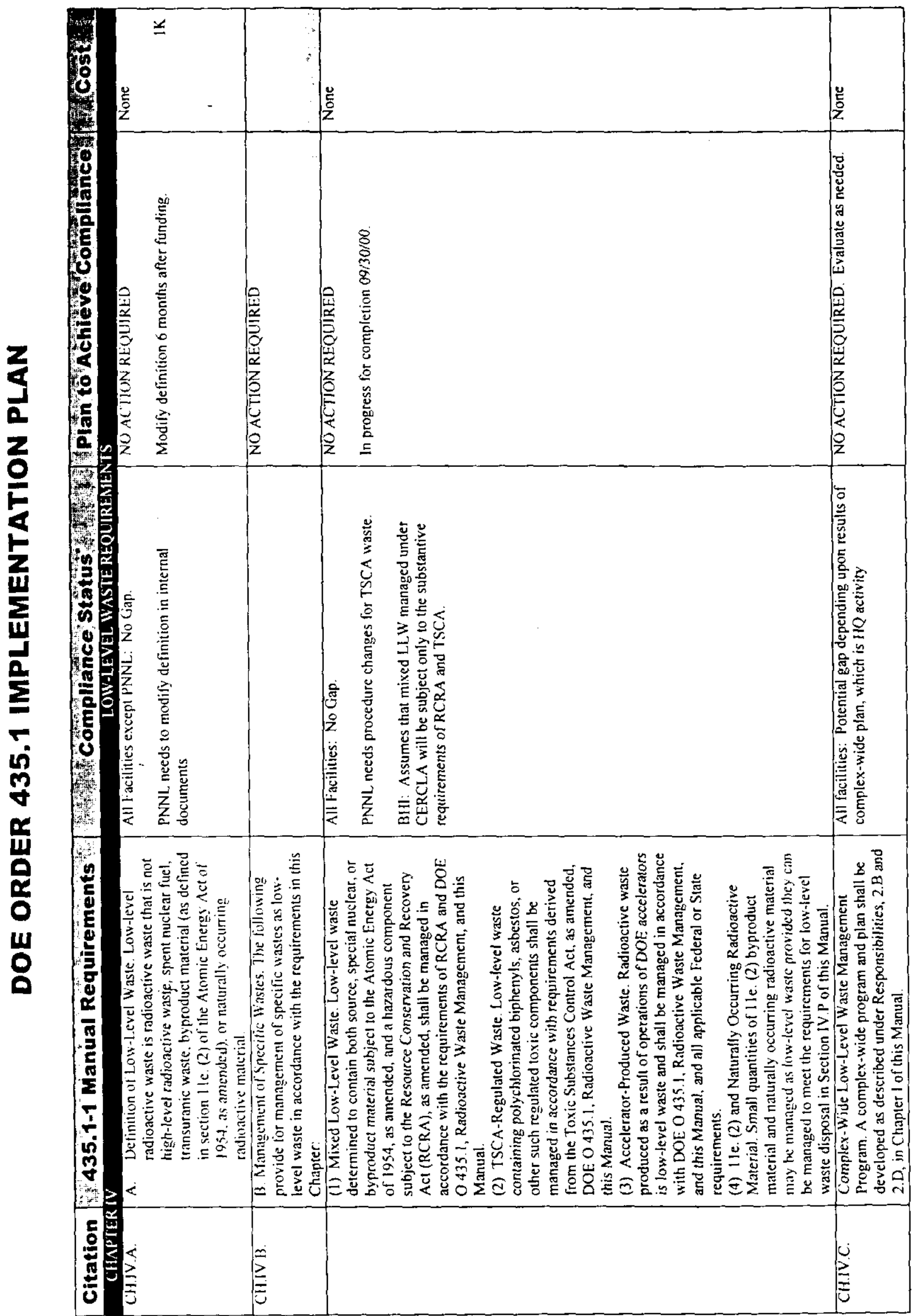




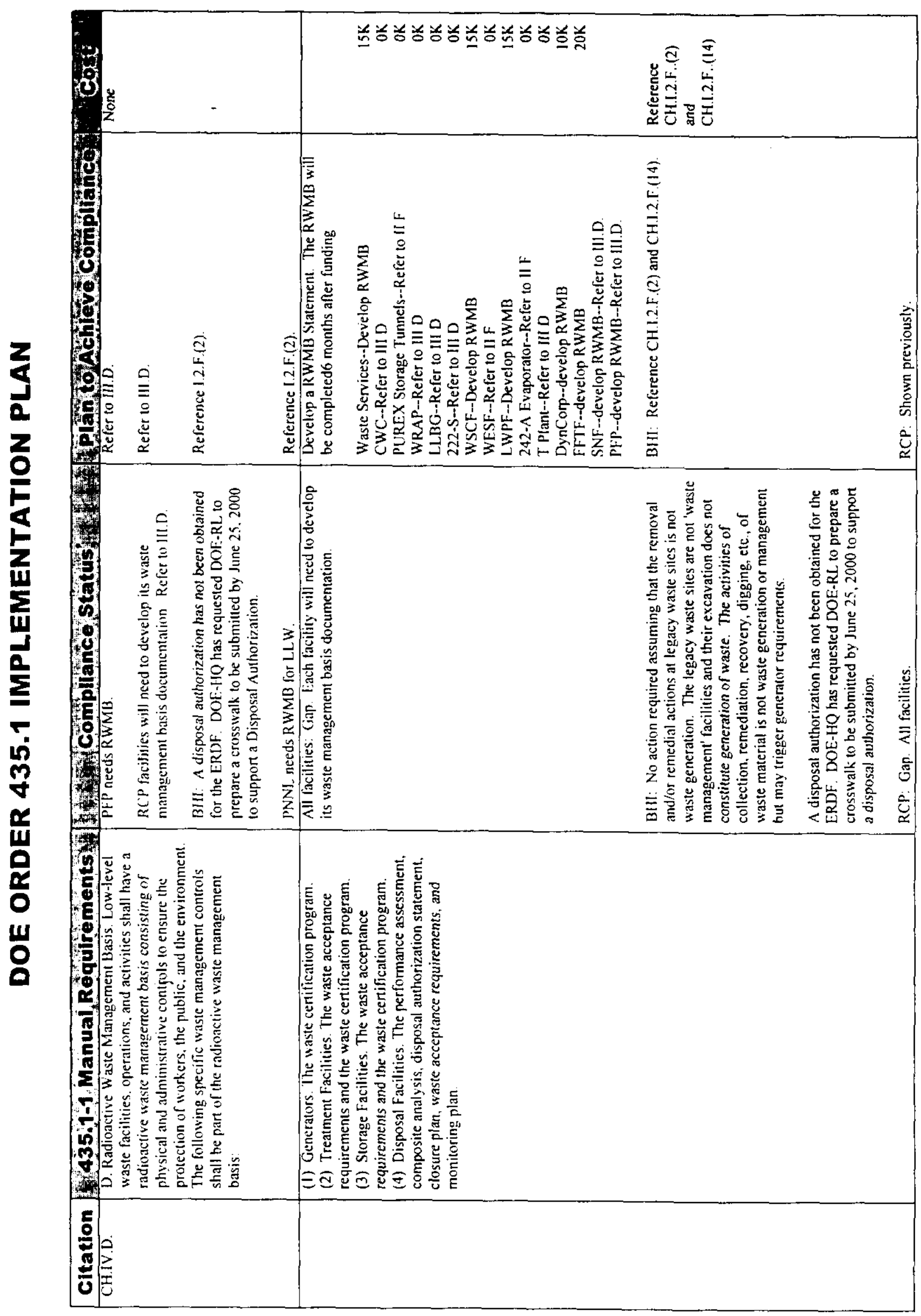




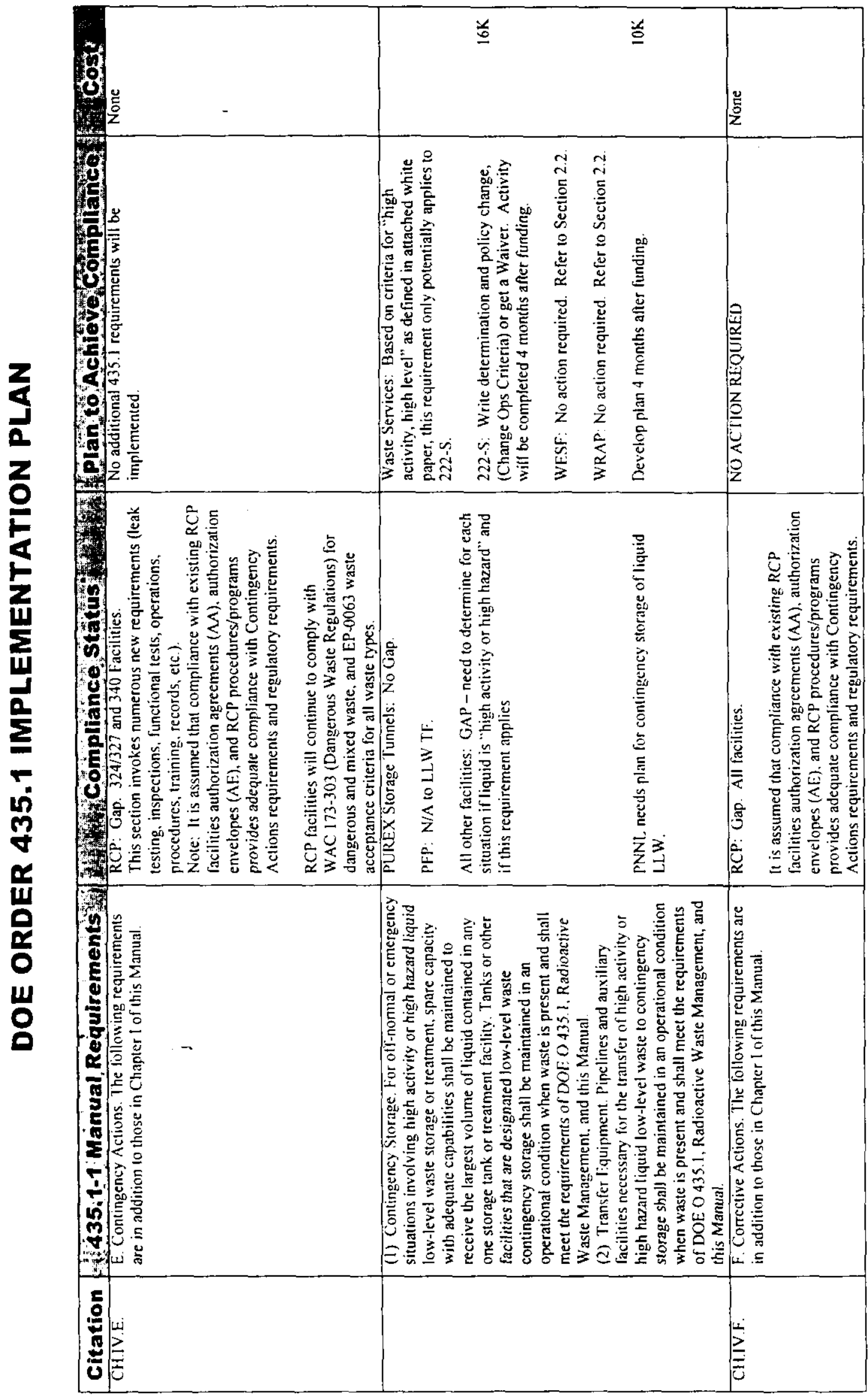


DOE/RI,-2000-25, Rev. 1

$06 / 2000$

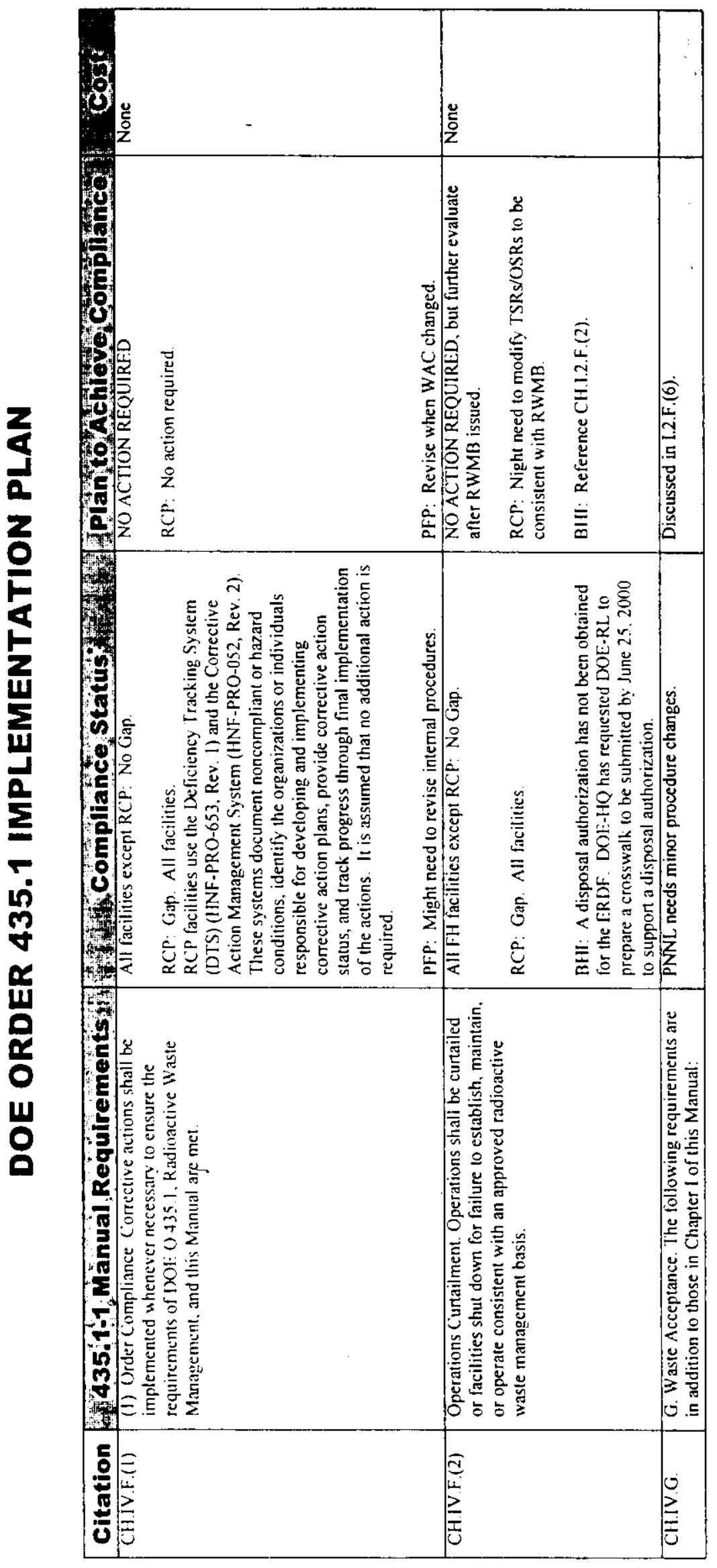

000710.0929

APP A-44 
DOE/RL-2000-25, Rev. 1

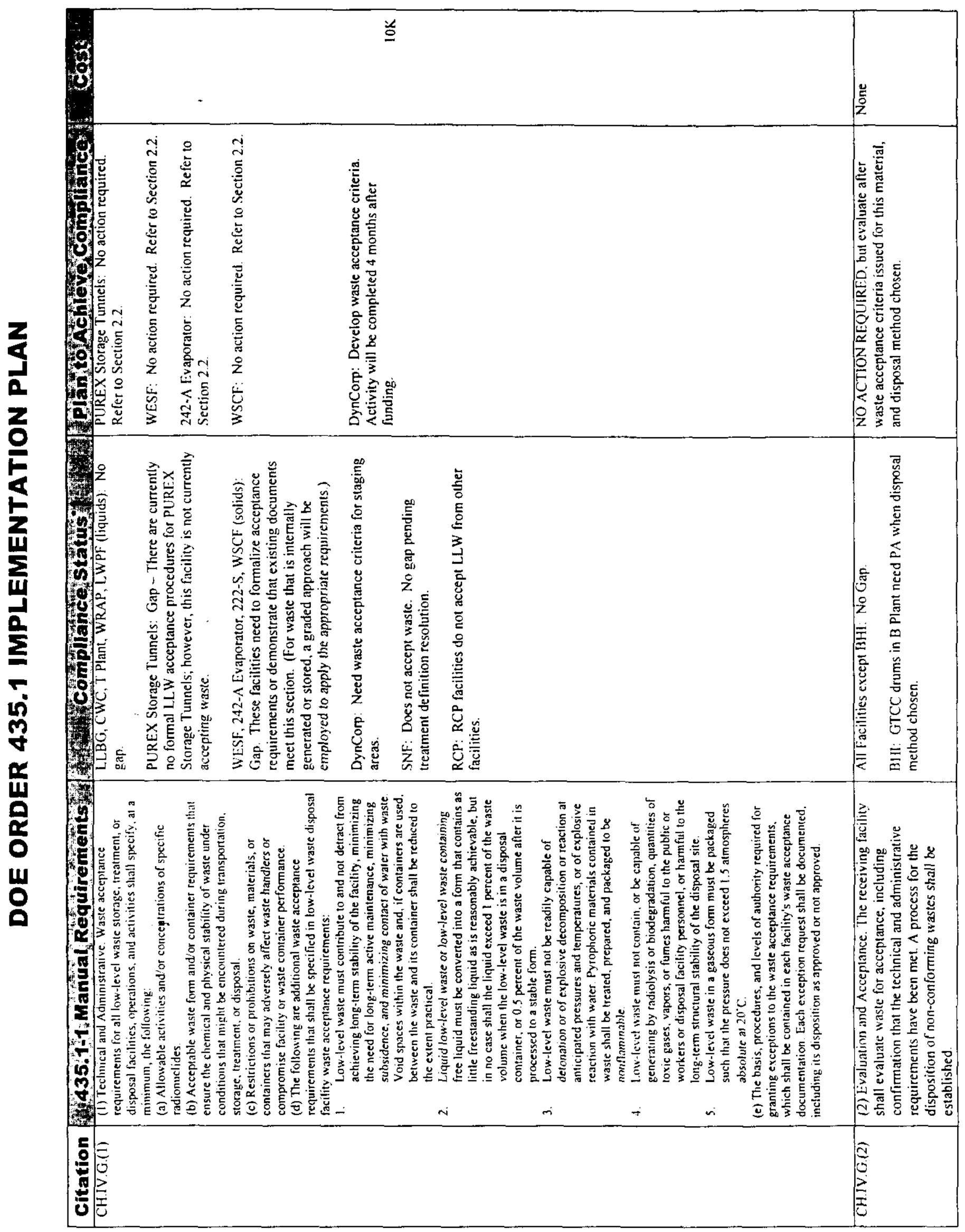


DOE/RL-2000-25, Rev. 1

06/2000

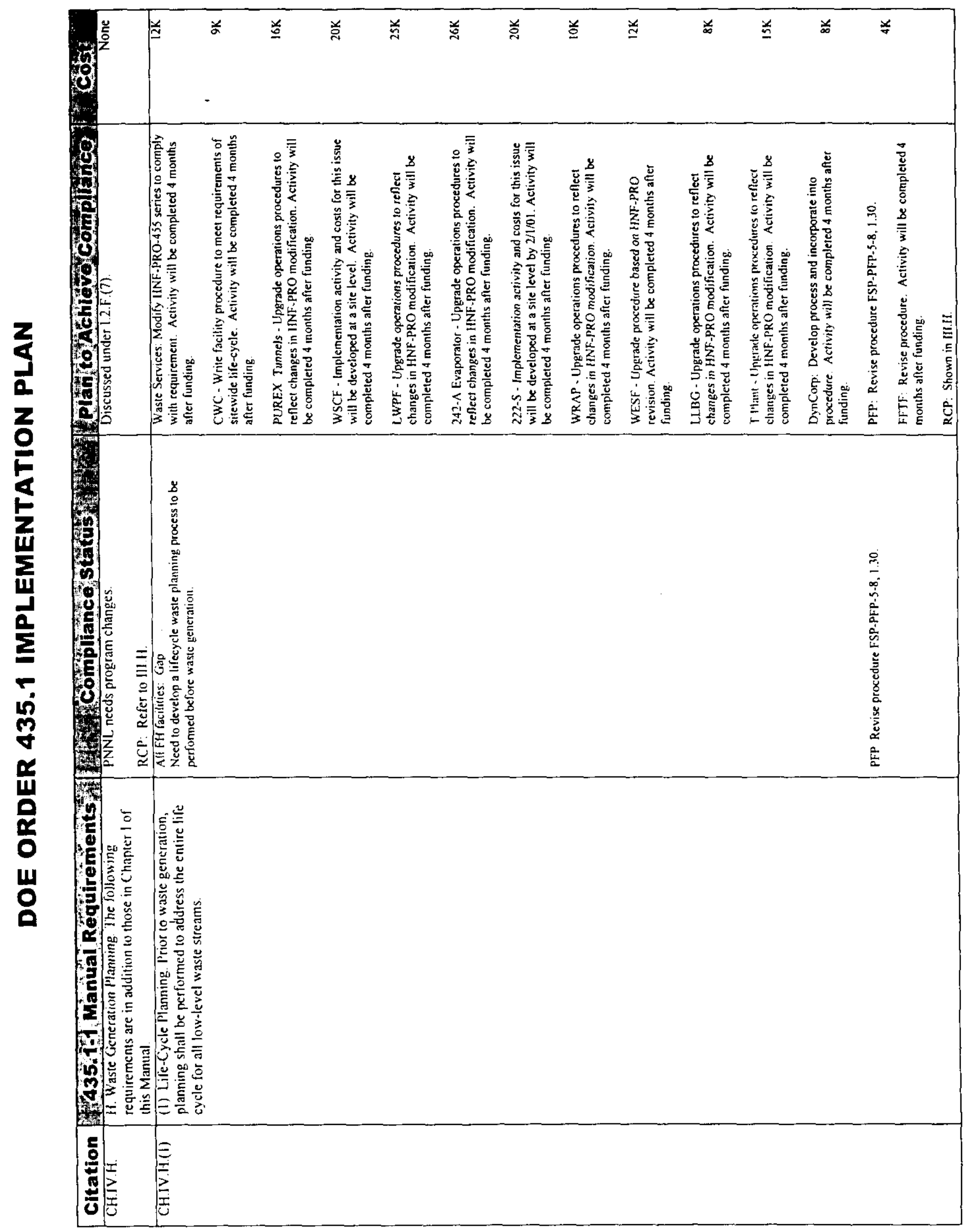


DOE/RL-2000-25, Rev. 1

$06 / 2000$

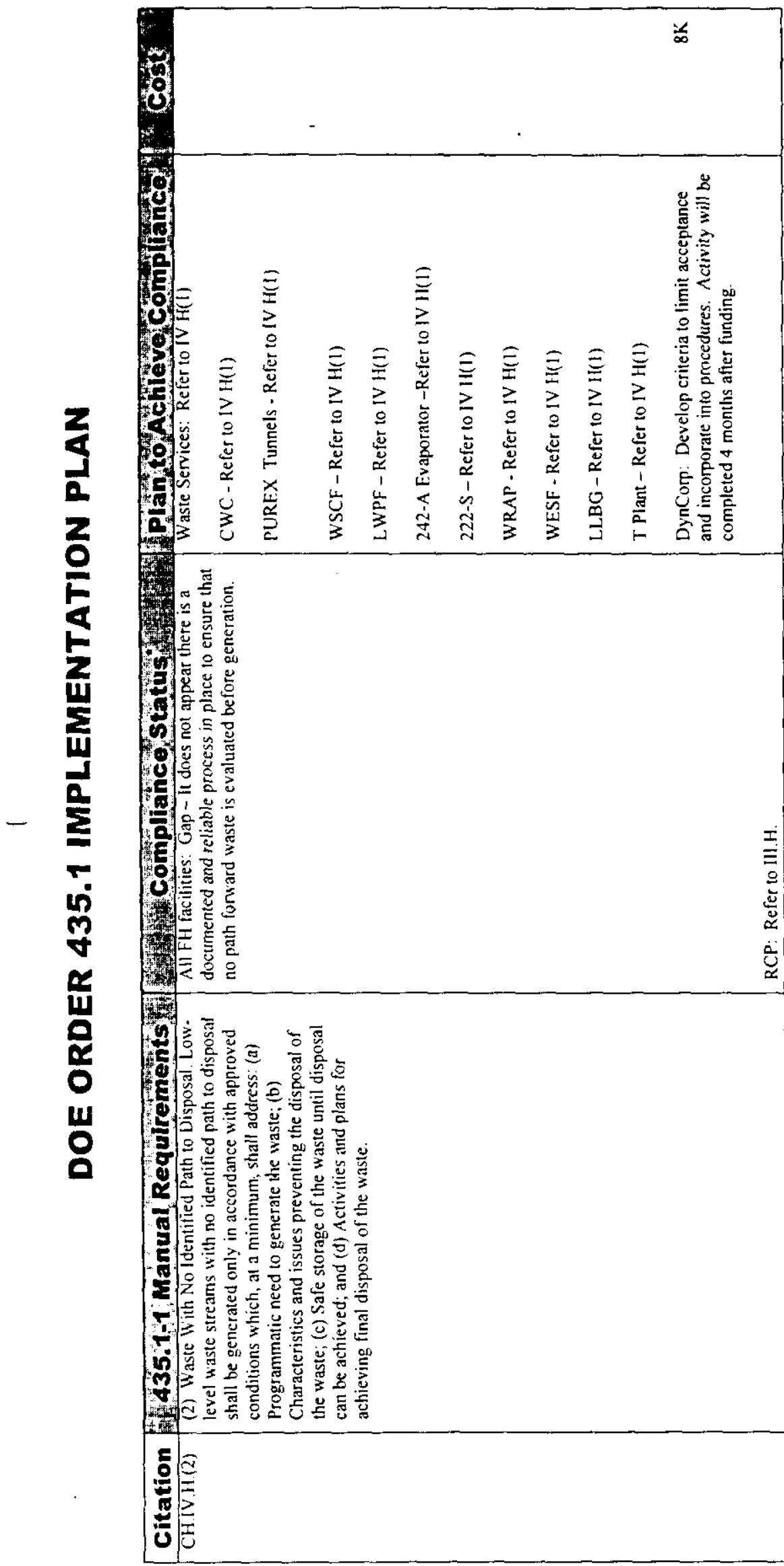


DOE/RL-2000-25, Rev. 1

$06 / 2000$

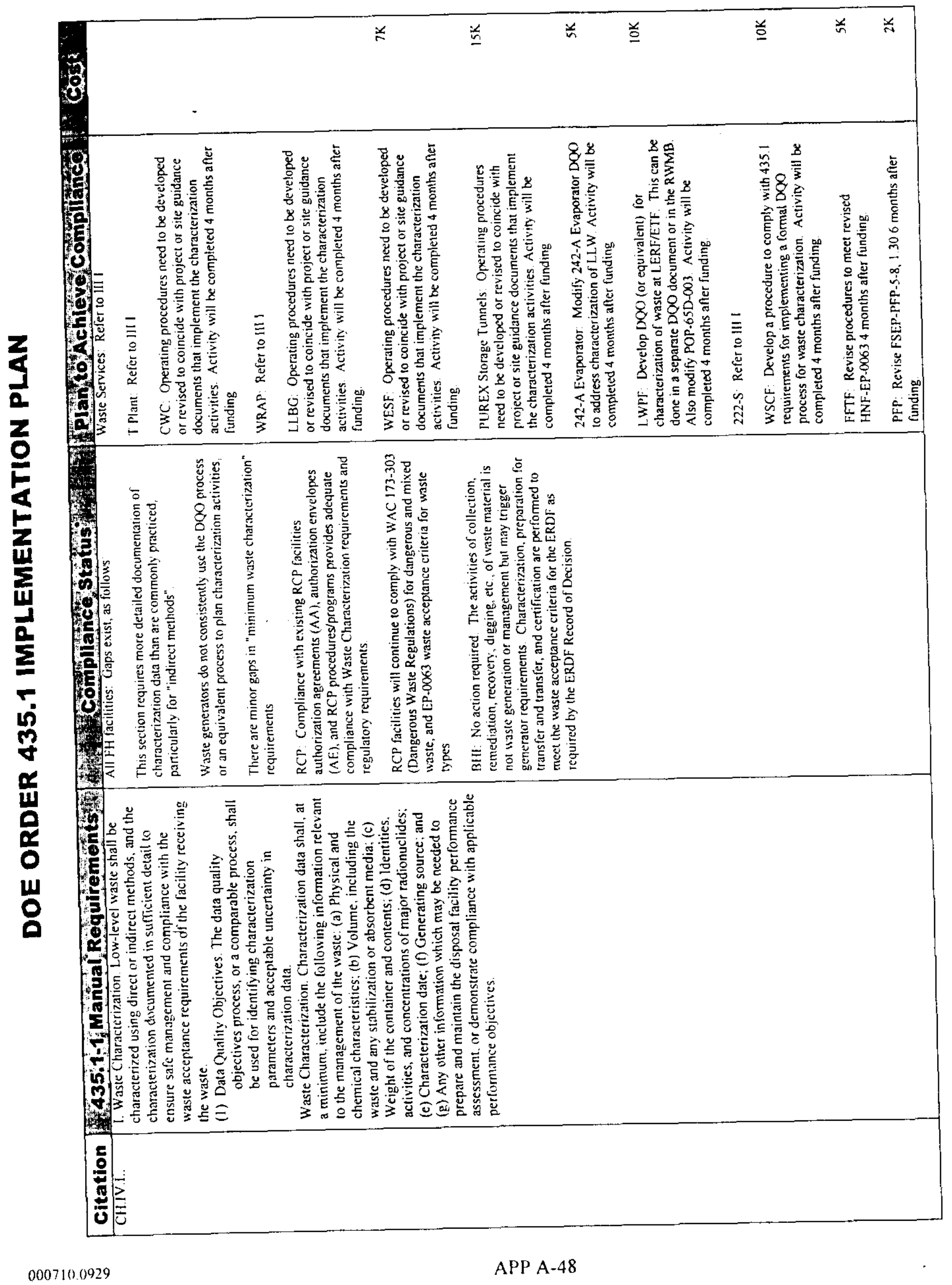




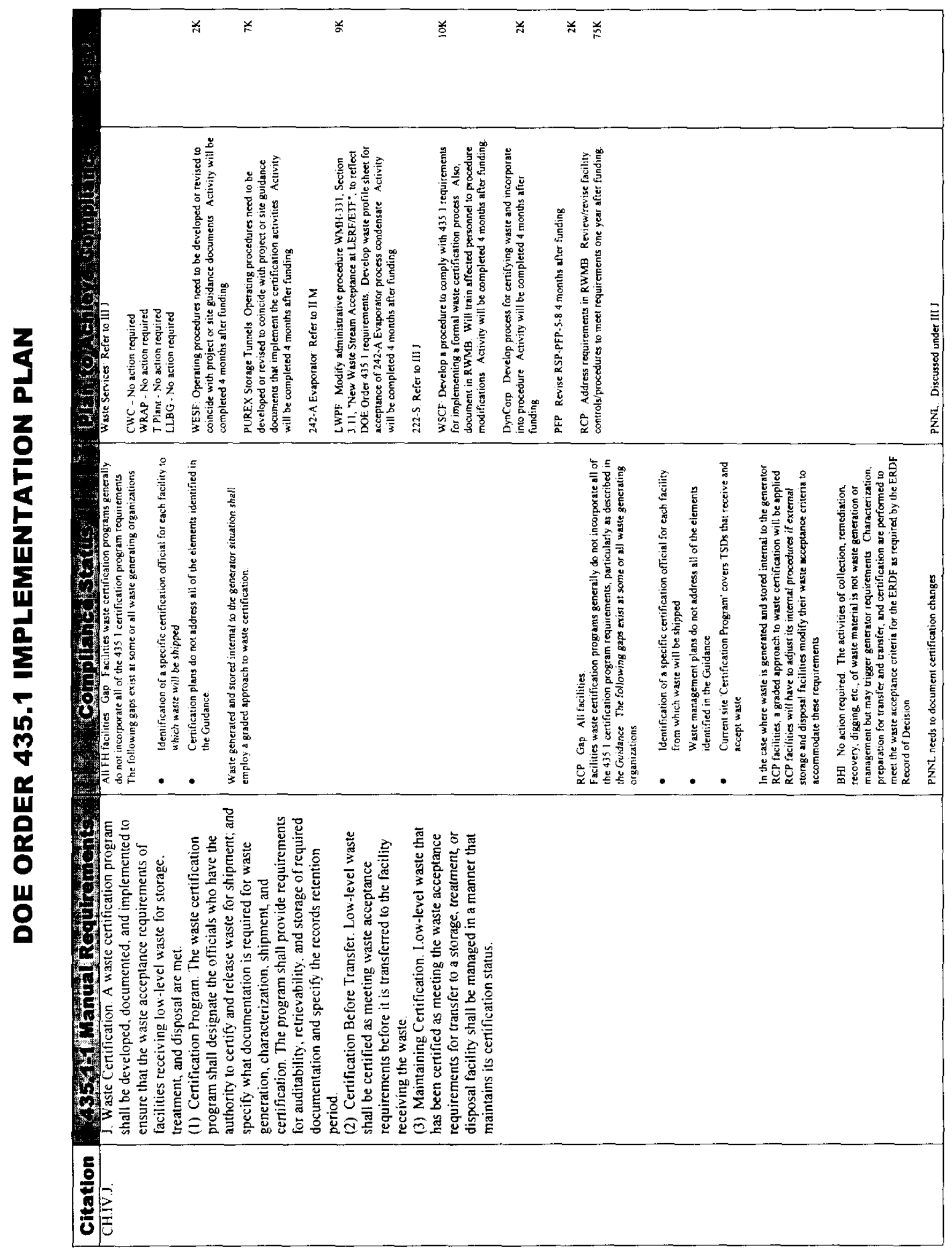




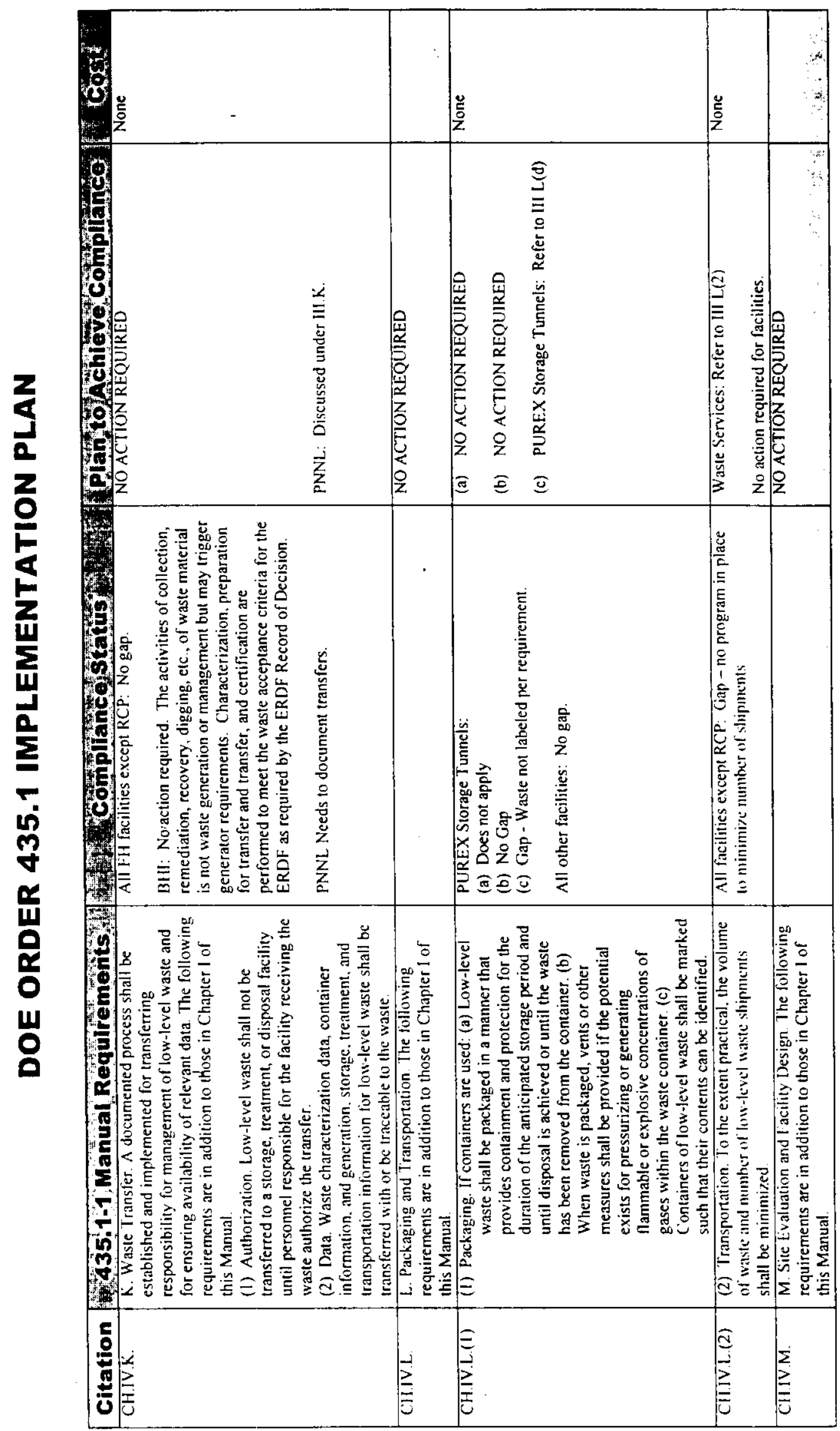




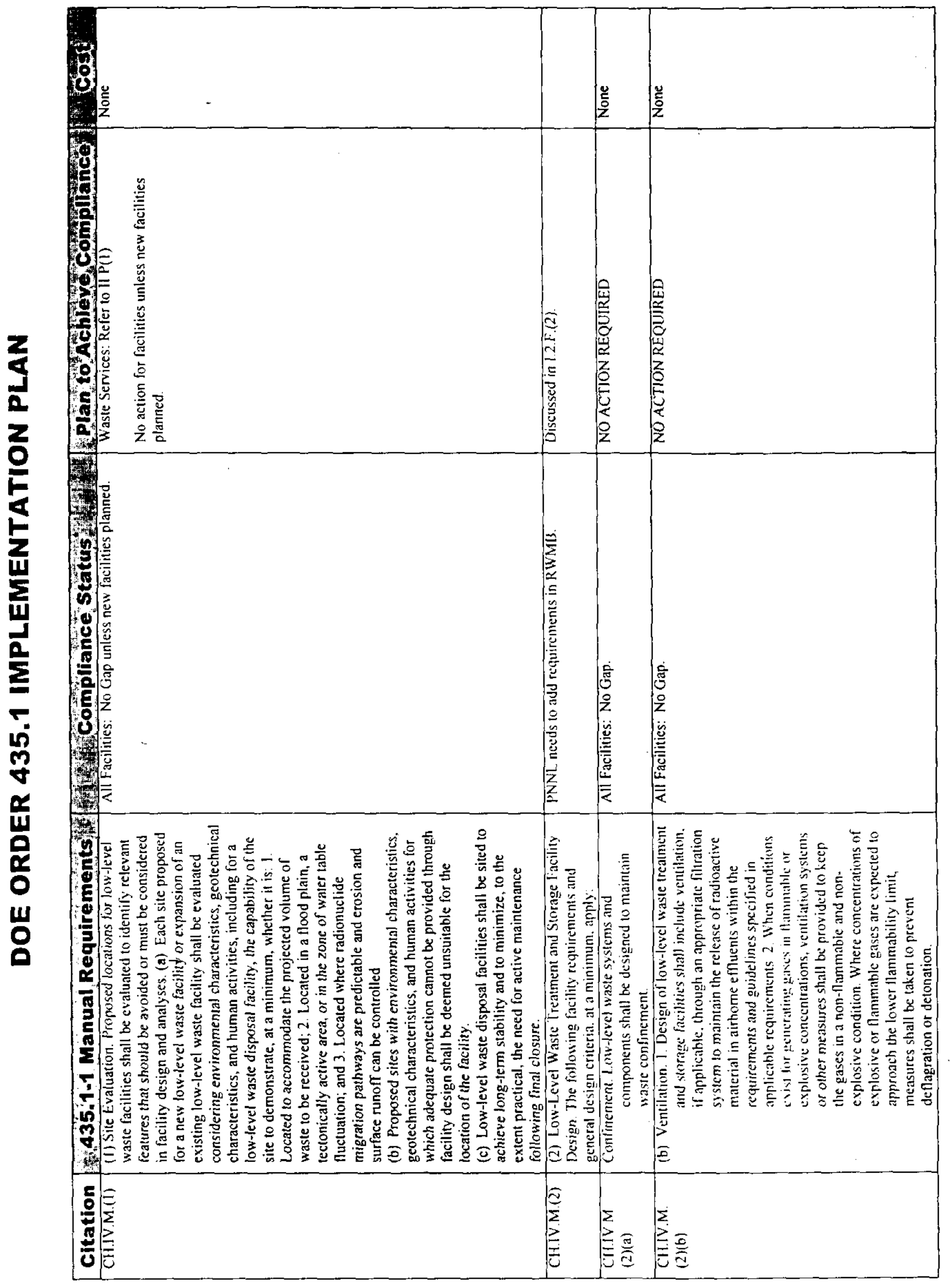


DOE/RL-2000-25, Rev. 1

$06 / 2000$

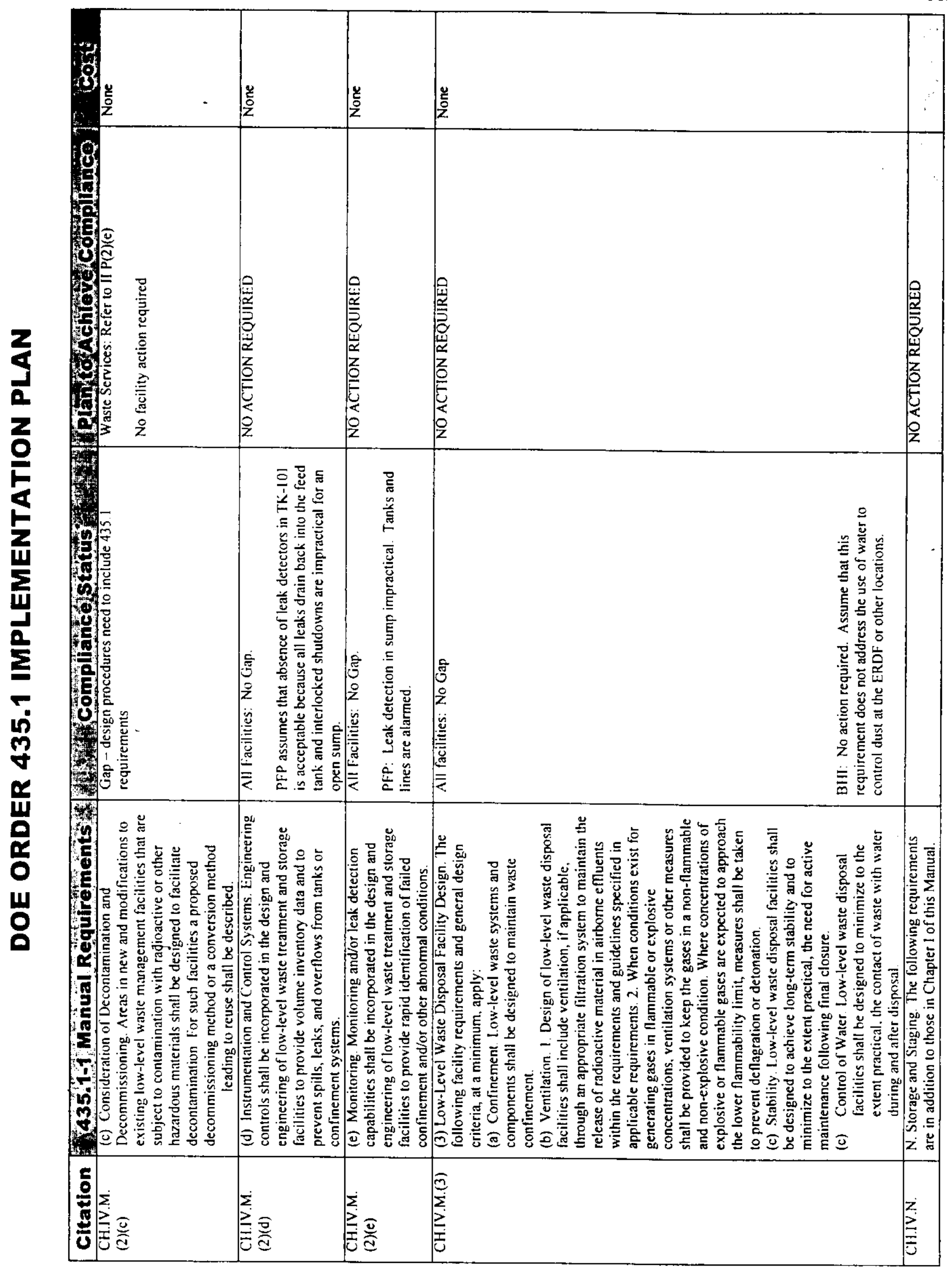


DOE/RL-2000-25, Rev. 1

$06 / 2000$

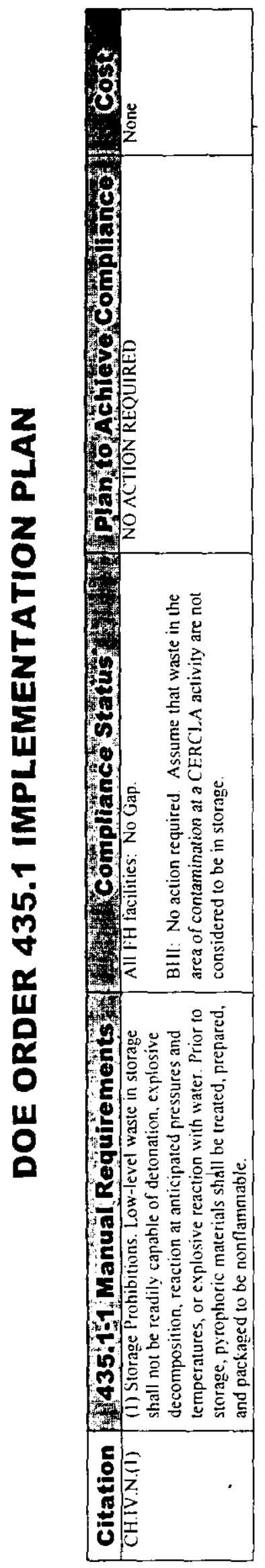


DOE/RL-2000-25, Rev. 1

$06 / 2000$

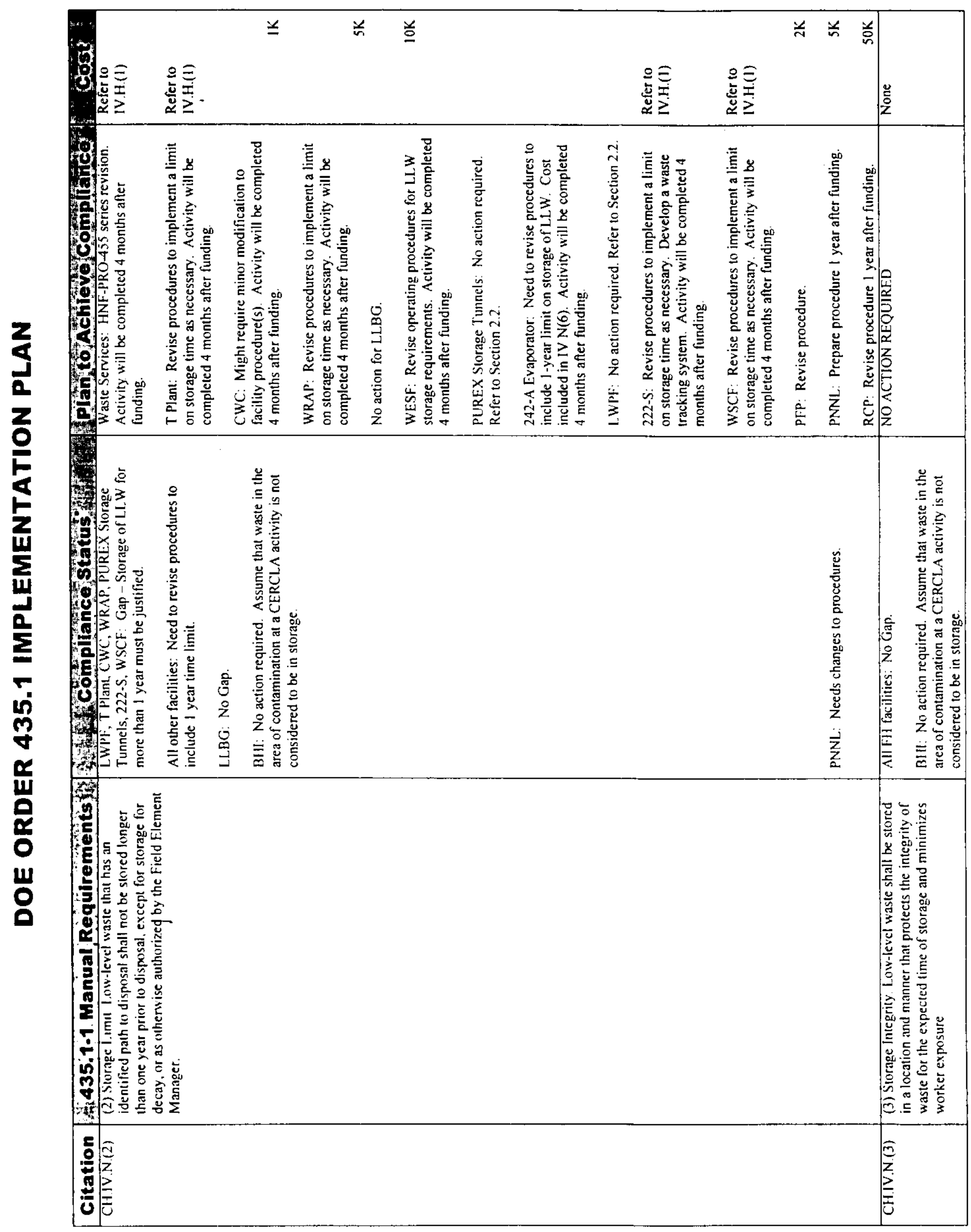




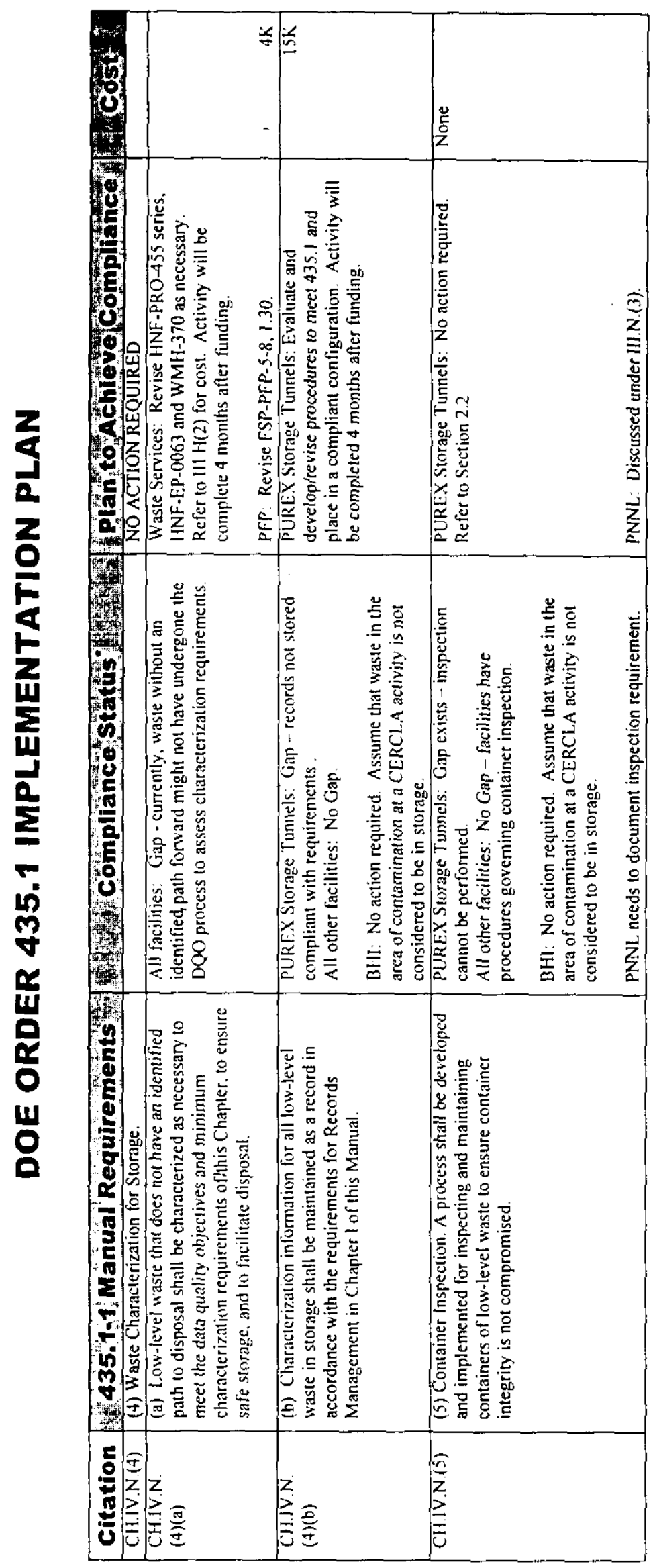


DOE/RL-2000-25, Rev. 1

$06 / 2000$

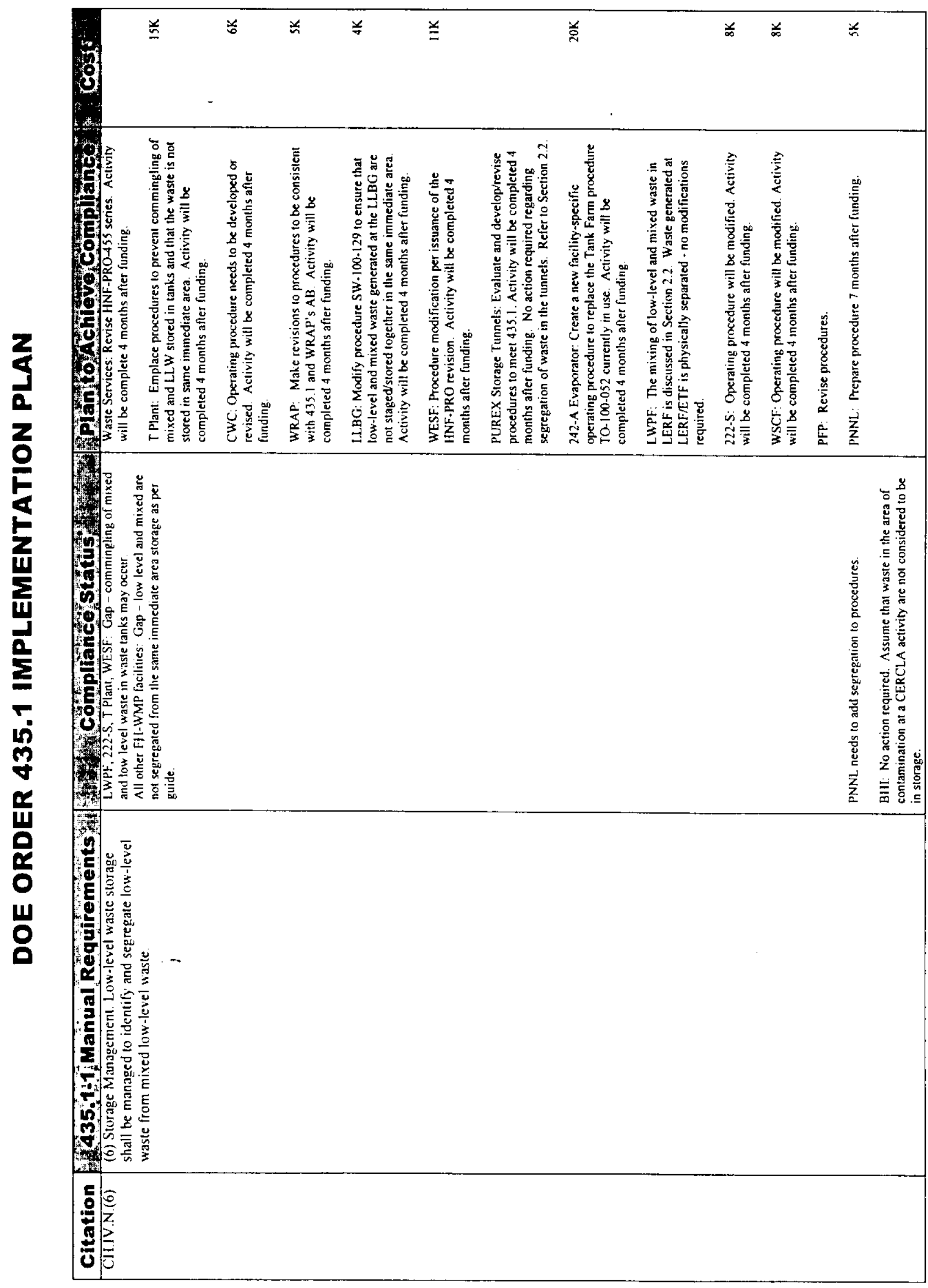


DOE/RL-2000-25, Rev. 1 $06 / 2000$

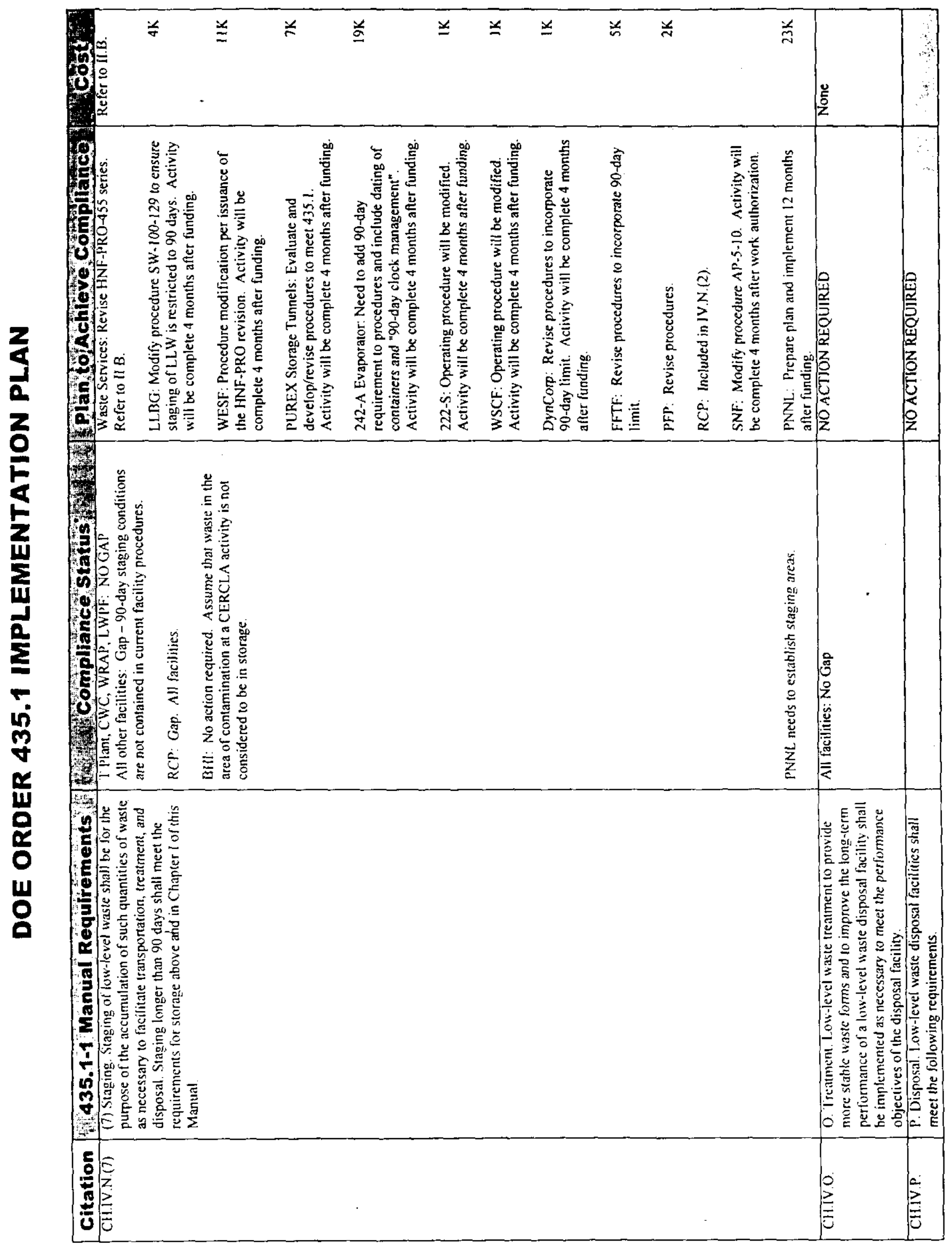


DOE/RL-2000-25, Rev. 1

$06 / 2000$

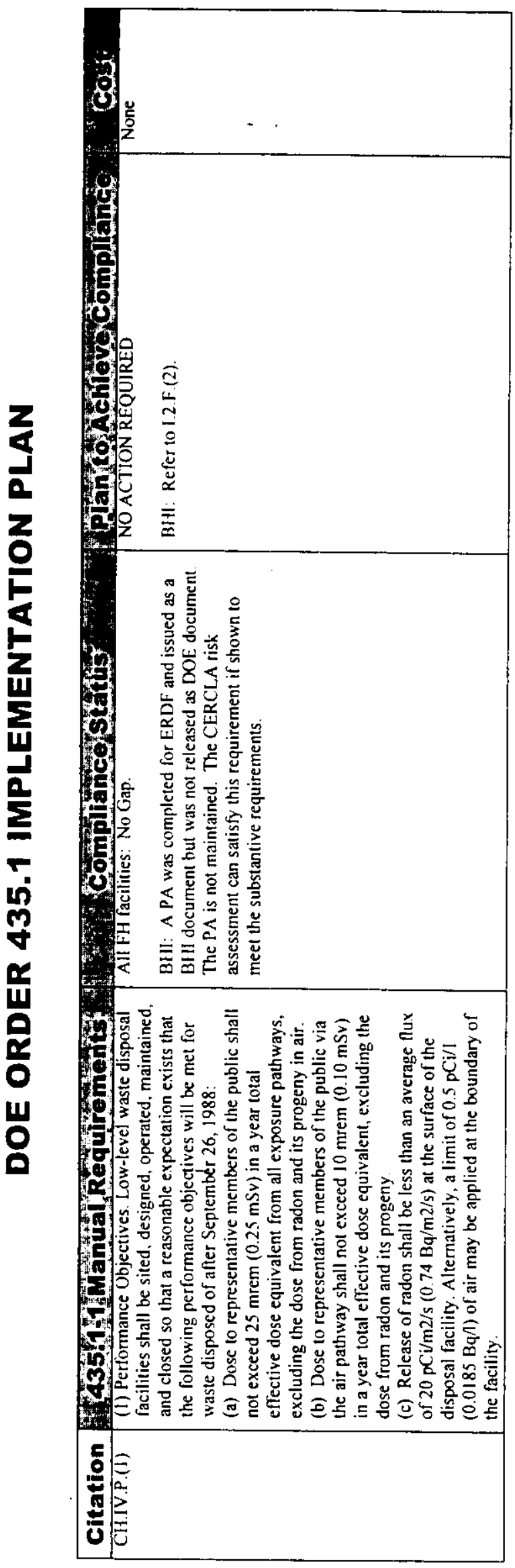




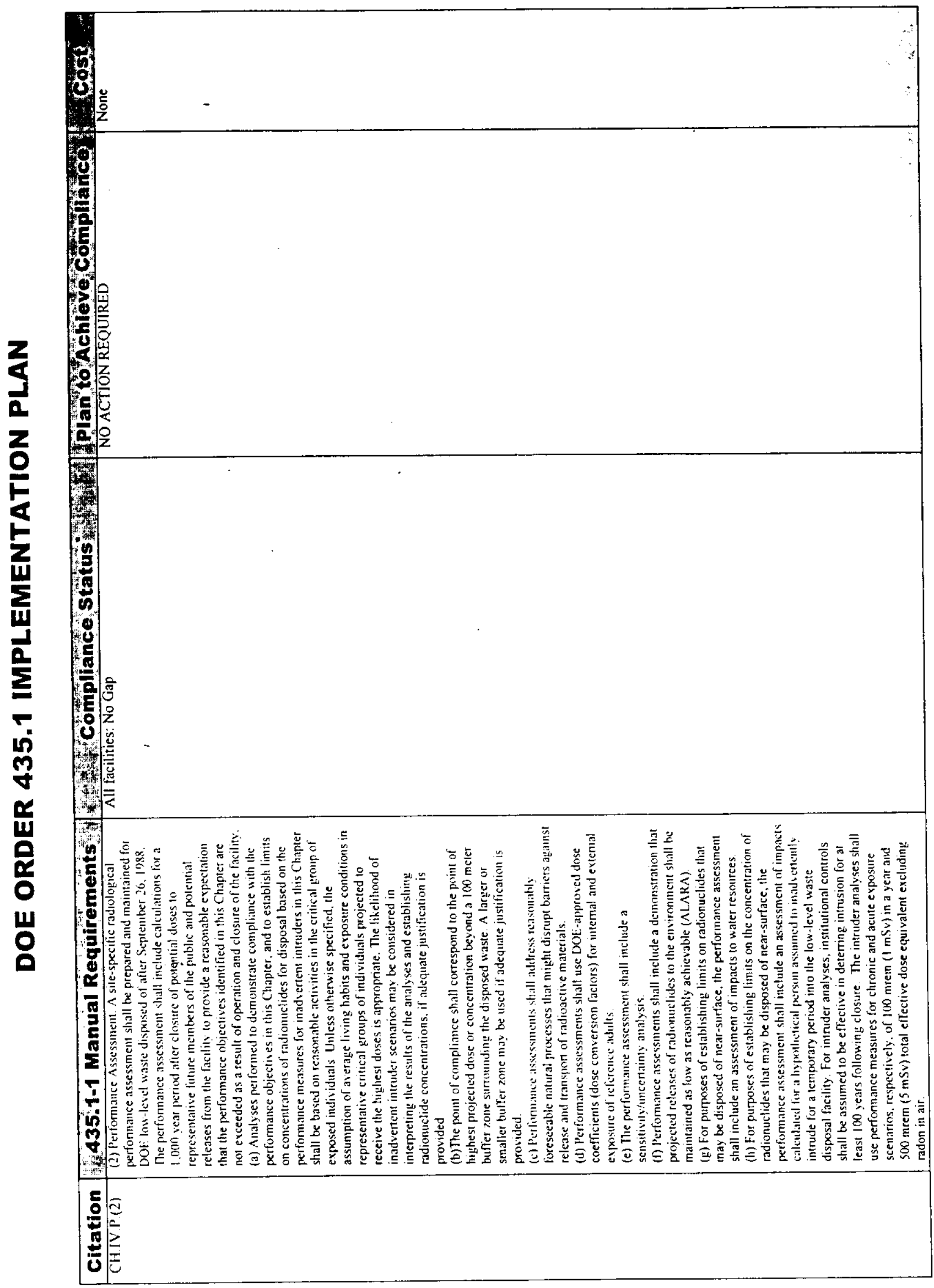


DOE/RL-2000-25, Rev. 1 $06 / 2000$

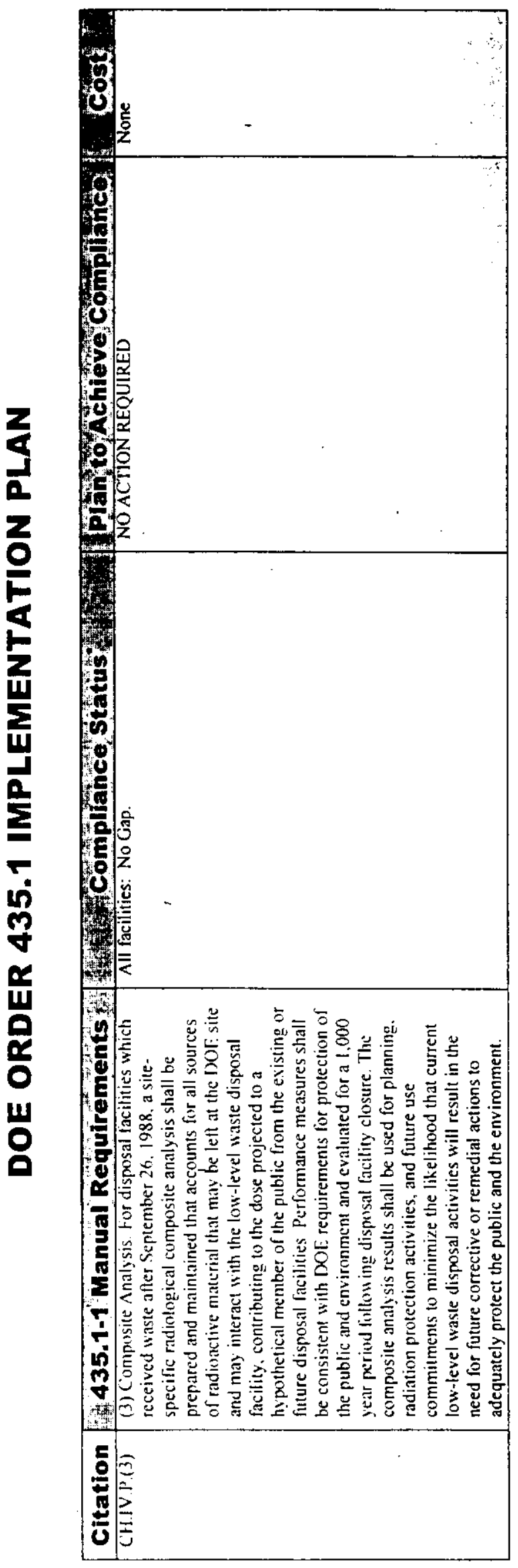




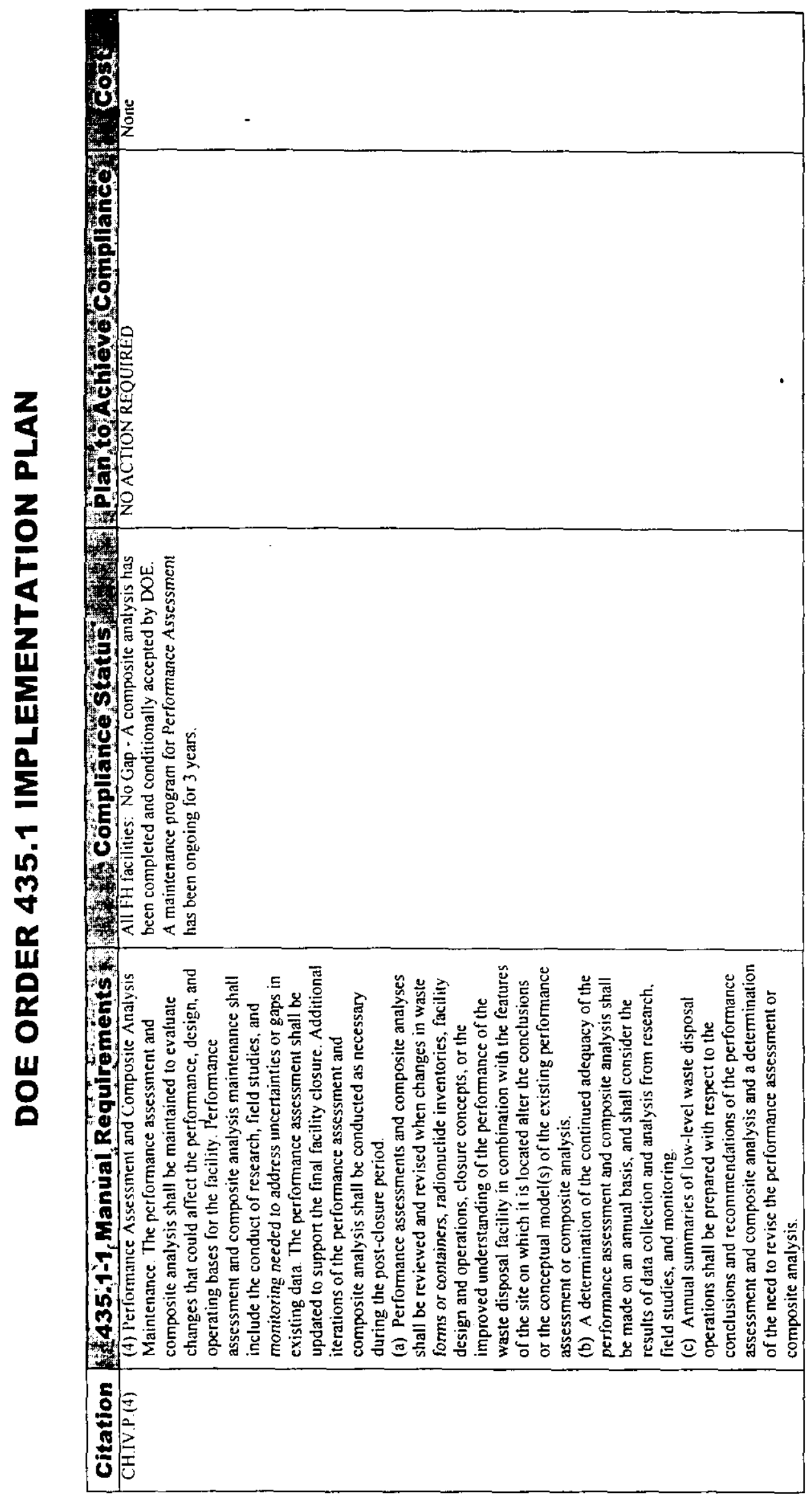




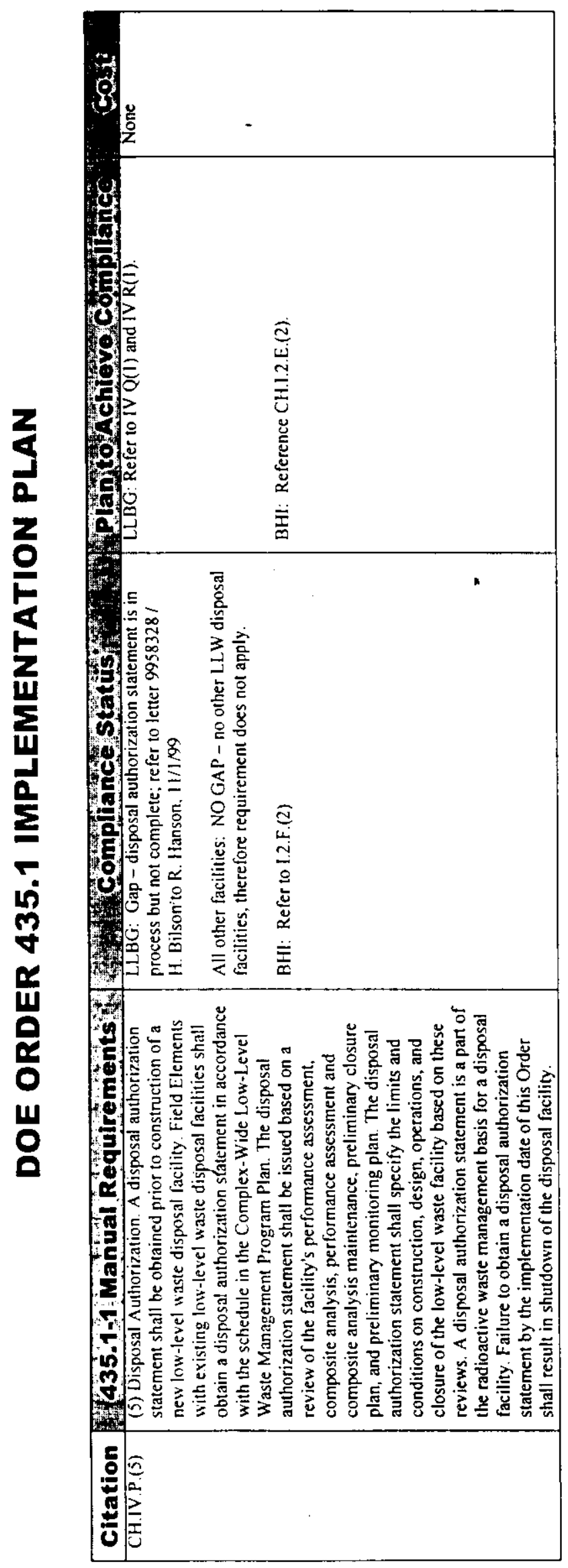


DOE/RL-2000-25, Rev. I

$06 / 2000$

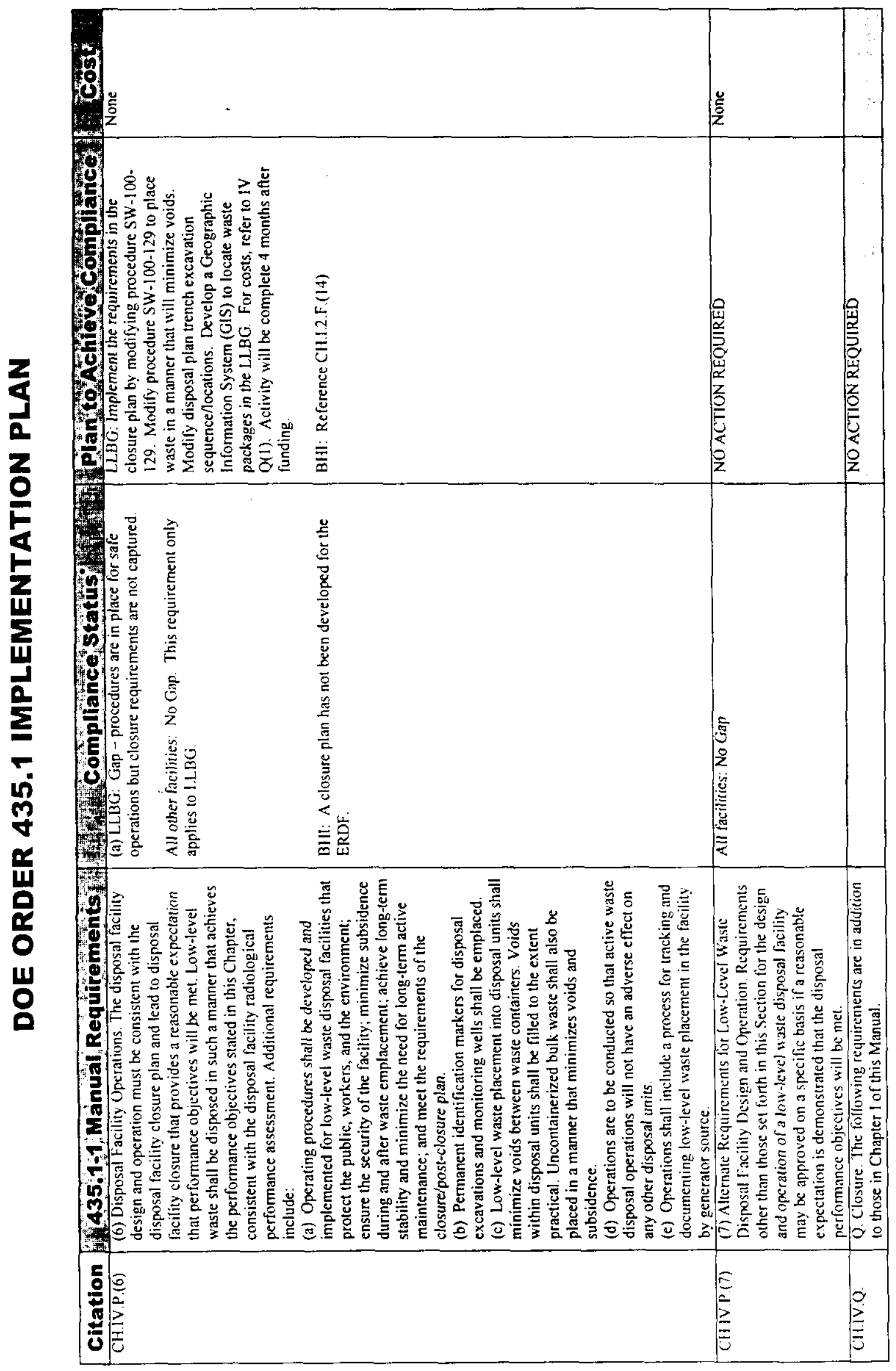


DOE/RL-2000-25, Rev. I $06 / 2000$

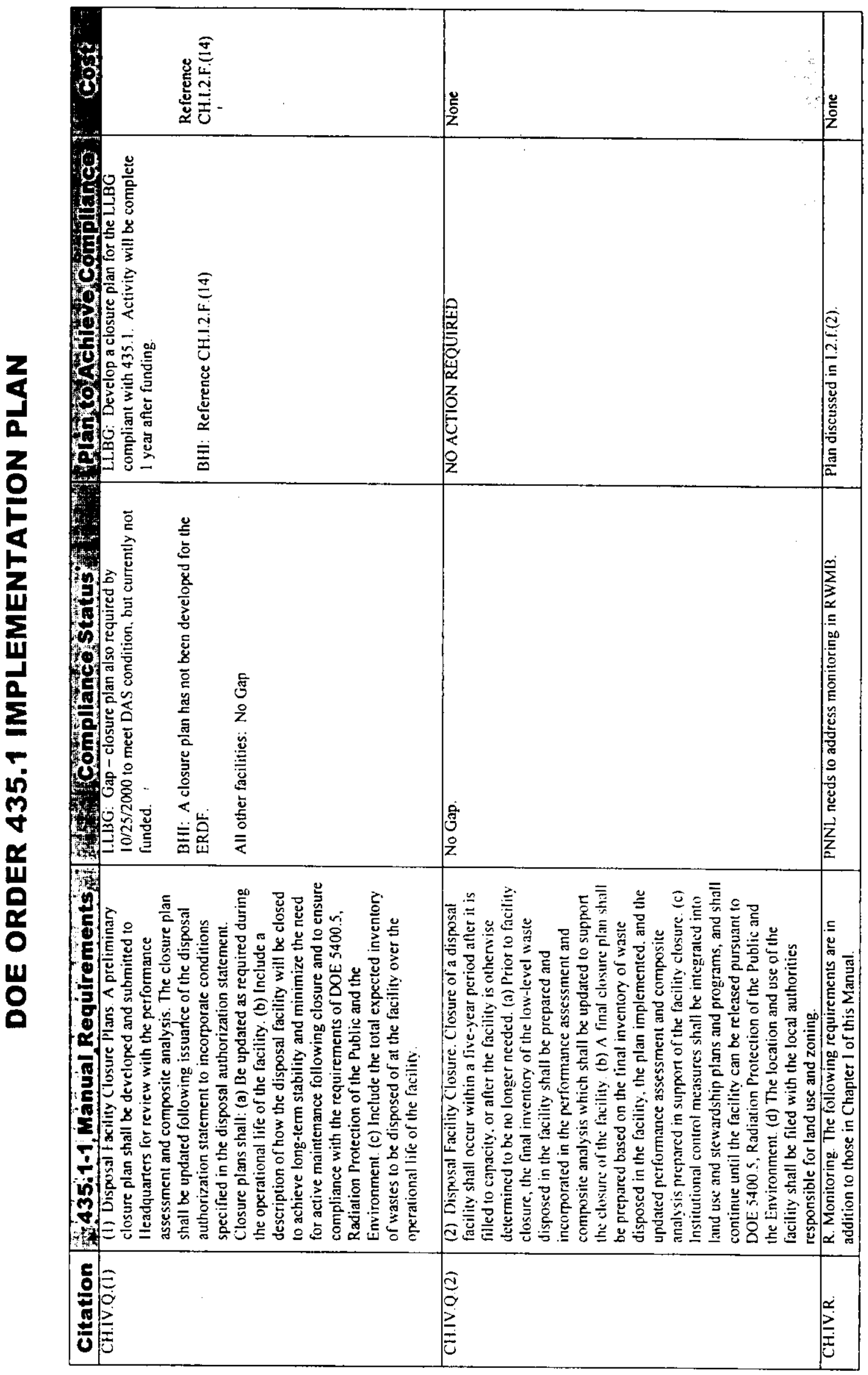


DOE/RL-2000-25, Rev. 1

$06 / 2000$

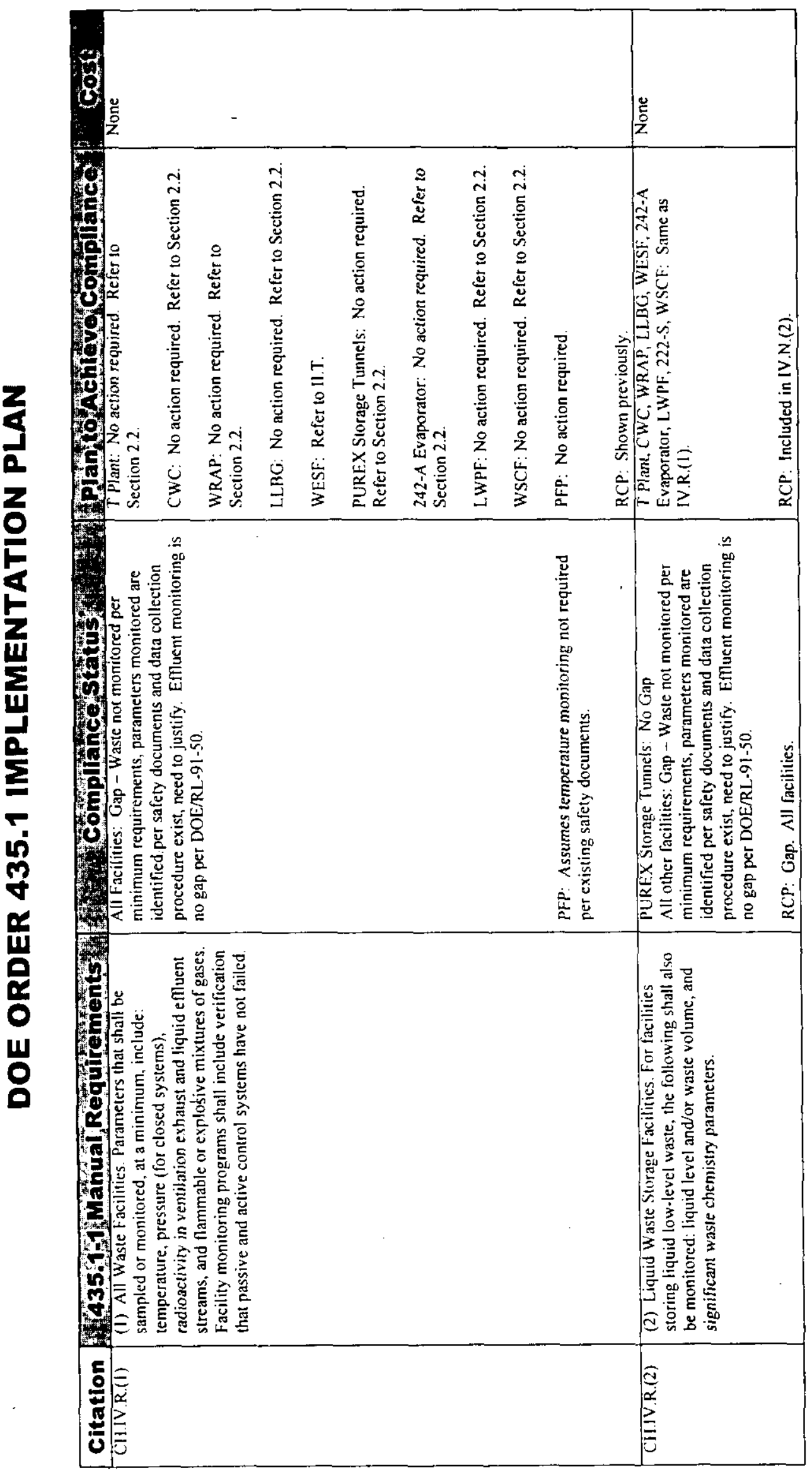


DOE/RL-2000-25, Rev. 1

$06 / 2000$

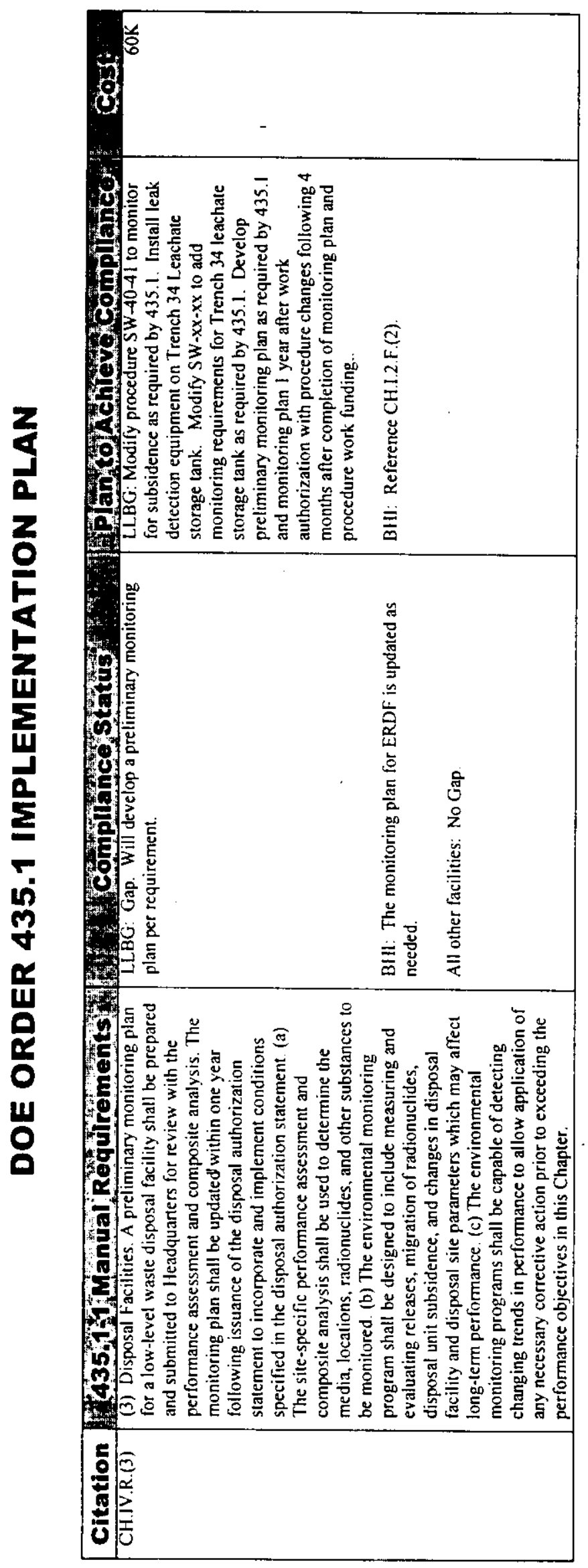


U.S. Department of Energy, Richland Operations Office

H. E. Bilson

$\mathrm{H} 0-12$

J. B. Hall

A2-15

R. A. Holten

A5-16

R. H. Guercia

S7-55

O. Robertson

$\mathrm{H} 0-12$

K. R. Westover

A5- 16

U.S. Department of Energy, Office of River Protection

D. D. Wodrich

H6-60

Fluor Hanford

L. T. Blackford

T3-04

J. B. Buckley

R. R. Connolly

T4-05

D. W. Fritz (5)

T3-04

R. H. Gurske

G1 -29

A. M. Kion

H8-73

C. P. Strand

B3-70

G. C. Triner

L6-04

J. L. Westcott (10)

T3-05

L. F. Willis

T3-04

H8-73

Beclitel Hanford, Inc.

L. M. Dittmer

H0-02

J. A. Handy

H0-16

R. J. Landon

H0-02

CH2M HILL Hanford Group

S. W. Sanders

S $7-71$

P. S. Schaus

R2-89

R. D. Wojtasek

R2-89

Pacific Northwest National Laboratory

M. W. McCoy

P7-28

W. K. Waller

P8-34

Lockheed Martin Services, Inc.

DPC

B 1-07

Central Files

H6-08

EDMC

H6-08 
DOE/RL-2000-25, Rev. 1

$06 / 2000$

\section{DISTRIBUTION}

MSIN

This page intentionally left blank. 